$$
\text { UNIVERSIDADE DE SÃO PAULO }
$$

FACULDADE DE FILOSOFIA, CIÊNCIAS E LETRAS DE RIBEIRÃO PRETO DEPARTAMENTO DE FÍSICA E MATEMÁTICA

OTÁVIO RIANI DE OLIVEIRA

\title{
Determinação experimental dos perfis de espalhamento de tecidos mamários (normais e alterados) e sua potencialidade como ferramenta de diagnóstico
}

\author{
Dissertação apresentada ao Curso de \\ Mestrado em Física Aplicada à Medicina e \\ Biologia como requisito parcial à obtenção do \\ grau de Mestre em Ciências. \\ Universidade de São Paulo \\ Orientador: Prof. Dr. Martin Eduardo Poletti
}

RIBEIRÂO PRETO, SP - BRASIL

MARÇO DE 2006 


\section{OTÁVIO RIANI DE OLIVEIRA}

Determinação experimental dos perfis de espalhamento de tecidos mamários (normais e alterados) e sua potencialidade como ferramenta de diagnóstico

Esta dissertação foi julgada adequada à obtenção do grau de Mestre e aprovada em sua forma final pelo Curso de Mestrado em Física Aplicada à Medicina e Biologia da Faculdade de Filosofia, Ciências e Letras de Ribeirão Preto, da Universidade de São Paulo. Ribeirão Preto, março de 2006.

Prof. Dr. Martin Eduardo Poletti

Orientador - Universidade de São Paulo

Prof. Dr. Thomaz Ghilardi Neto

Universidade de São Paulo

Prof. Dr. Paulo Roberto Costa

Universidade de São Paulo 
Oliveira, Otávio Riani de

Determinação experimental dos perfis de espalhamento de tecidos mamários (normais e alterados): uma nova fonte de informação histológica na mamografia / Otávio Riani de Oliveira; Orientação: Prof. Dr. Martin Eduardo Poletti, Ribeirão Preto: FFCLRP / USP, 2006.

Dissertação (Mestrado) apresentada à Faculdade de Filosofia, Ciências e Letras de Ribeirão Preto - Universidade de São Paulo.

1. Espalhamento de Raios-X.

3. Câncer de mama.

2. Tecido mamário.

4. Radiodiagnóstico. 
À minha família, amigos, colegas e educadores 


\section{AGRADECIMENTOS}

Este trabalho é o resultado de um esforço coletivo de todas as pessoas que participaram do meu desenvolvimento pessoal e profissional. Não há palavras que conseguem descrever o verdadeiro e imensurável sentimento de gratidão a todas elas:

A Deus, pela vida, saúde, paz, iluminação e força de vontade e oportunidades a mim concedidas.

Aos meus pais e irmãos, Edir e Onice, Gisela e Alisson, pelo amor e incentivos incondicionais.

Ao Prof. Dr. Martin Eduardo Poletti, pelo excelente trabalho de orientação tanto ao longo do programa de mestrado, quanto na escrita desta dissertação.

Ao Prof. Dr. Alfredo Ribeiro Silva, pela experiência transmitida na área de Patologia de Doenças Mamárias.

Aos parceiros do grupo de trabalho, Marina Piacenti Silva, Alessandra Tomal, e em especial, Diego Merigue da Cunha, pela sabedoria compartilhada.

Ao técnico Carlão, responsável pelo Laboratório de Difractometria, pela ajuda prestada nos experimentos realizados neste trabalho.

Ao Departamento de Patologia do Hospital das Clínicas da Faculdade de Medicina da USP de Ribeirão Preto pelas amostras de tecido mamário cedidas, sem as quais este trabalho não se tornaria possível. 
Ao pessoal das secretarias do Departamento de Física e Matemática e da Faculdade de Filosofia, de Ciências e Letras da USP de Ribeirão Preto, pela, sempre presente, boa vontade nos atendimentos.

Ao invisível pessoal da limpeza e manutenção, por tornou utilizável meu local de trabalho.

Aos grandes amigos de Juiz de Fora, por estarem sempre próximos tanto nos momentos difíceis, como nos de lazer e diversão.

Aos novos amigos encontrados aqui, pelo companheirismo sempre presente.

Ao pessoal da $\mathrm{R}^{3}$, Paulo César Dias Petchevist, Herofen Zaias e Diego Merigue da Cunha, pelo convívio diário e pelas experiências compartilhadas.

Ao Senhor Geraldo, zelador do Edifício Palmira Ferrari, pelas inúmeras ajudas prestadas.

À FAPESP, pela concessão da bolsa ao projeto "Determinação Experimental dos Perfis de Espalhamento de Tecidos Mamários (normais e alterados): uma nova fonte de informação histológica na mamografia", processo 02/06270-0 e pelo apoio financeiro ao projeto Jovem Pesquisador em centros emergentes “Caracterização Histopatológica de Tecidos Mamários através da Radiação Secundária”, processo 02/00380-3. 


\section{RESUMO}

OLIVEIRA, O. R. Determinação experimental dos perfis de espalhamento de tecidos mamários (normais e alterados) e sua potencialidade como ferramenta de diagnóstico. [Dissertação]. Ribeirão Preto: Faculdade de Filosofia Ciências e Letras de Ribeirão Preto, Universidade de São Paulo; 2006. 78 p.

A distribuição angular de fótons espalhados (perfil de espalhamento) pode fornecer informações sobre as estruturas que compõe um tecido biológico, permitindo, a partir da análise desta, identificar a presença de anormalidades no tecido. A proposta deste trabalho foi desenvolver um procedimento experimental de medidas do perfil de espalhamento de tecidos mamários normais e alterados e, posteriormente, correlacionar as informações contidas neste com informações histopatológicas do tecido. Os perfis de espalhamento foram medidos no intervalo de momento transferido entre $0,2 \leq \chi \leq 6,2 \mathrm{~nm}^{-1}$, utilizando um difractômetro Siemens D-5005, com ânodo de cobre e operando no modo reflexão. As amostras de tecidos mamários foram previamente classificadas como: tecidos normais, fibroadenomas e carcinomas. As intensidades medidas foram corrigidas por atenuação, efeitos geométricos e pela variação angular do feixe incidente. A eficácia do procedimento experimental foi validada através do uso de dados de referência para amostras de água. Os resultados mostraram que o perfil de espalhamento é uma característica única de cada tipo de tecido, sendo sua forma relacionada à morfologia microscópica do tecido. Na região em que $\chi \leq 0,35 \mathrm{~nm}^{-1}$, verificou-se estatisticamente que as informações contidas nos perfis de espalhamento permitem a diferenciação entre tecidos normais e alterados.

Palavras chave: perfis de espalhamento, mamografia, patologias mamárias. 


\begin{abstract}
OLIVEIRA, O. R. Experimental determination of scattering profiles form breast tissues (normal and altered) and its potentiality as a diagnostic tool. [Dissertação]. Ribeirão Preto: Faculdade de Filosofia Ciências e Letras de Ribeirão Preto, Universidade de São Paulo; 2006. $78 \mathrm{p}$.
\end{abstract}

Angular distribution of photons scattered by tissues (scattering profile) gives detailed information of structures within them and provides an alternative mean of distinguishing pathologies. The proposal of this work was to develop an experimental procedure to determine scattering profiles from breast tissues (normal and neoplastic) and to correlate the information contained in these profiles with histopathological information. The scattering profiles were measured in the interval of momentum transfer $0,2 \leq \chi \leq 6,2$ $\mathrm{nm}^{-1}$, using a powder diffractomer apparatus (Siemens D-5005), with copper anode and operation in reflection mode. The breast samples were previously histopathologically classified as normal tissues, fibroadenomes and carcinomas. The measured angular distribution was corrected by attenuation, geometric effect and the angular variation of the incident beam. The effectiveness of the experimental procedure was validated through the use of water reference data. The results shown that, scattering profile is unique impression of each type of tissue, being correlated with the microscopic morphological features. In the region where $\chi \leq 0,35 \mathrm{~nm}^{-1}$, were statistically verified that the information contained in the scattering profiles allow the differentiation between normal and neoplastic breast tissues.

Keywords: X ray scattering profile, mammography, Breast Cancer. 


\section{ÍNDICE}

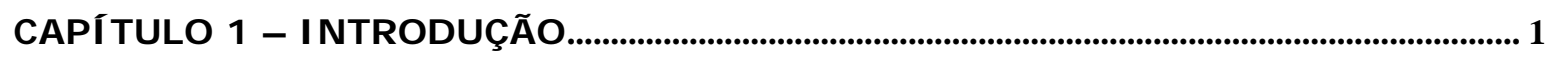

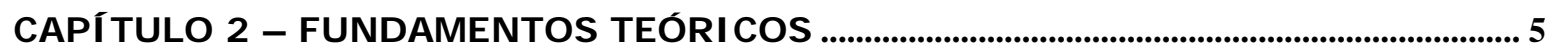

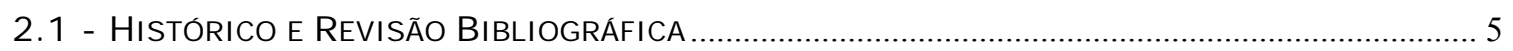

2.1.1 - O espalhamento no radiodagnóstico - desvantagem ........................................... 5

2.1.2 - O Espalhamento como ferramenta para a caracterização de tecidos -

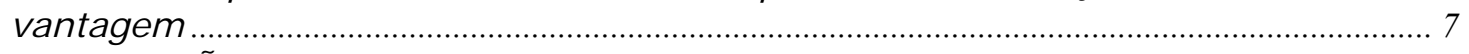

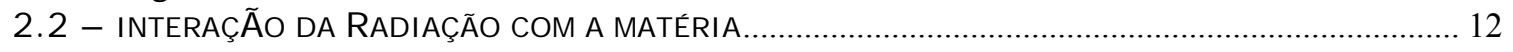

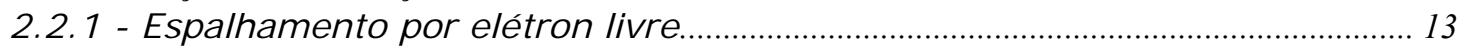

2.2.2. - Espalhamento por átomo livre.......................................................................... 15

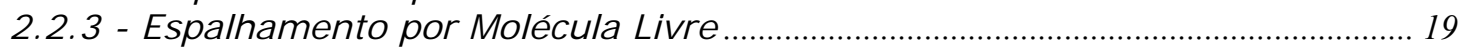

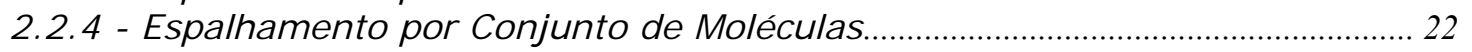

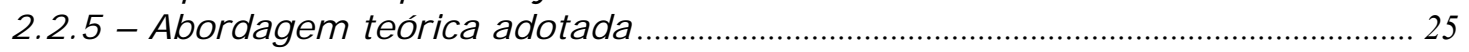

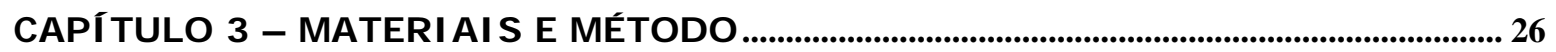

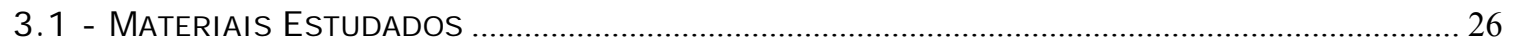

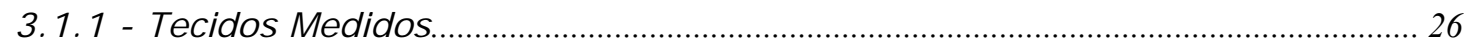

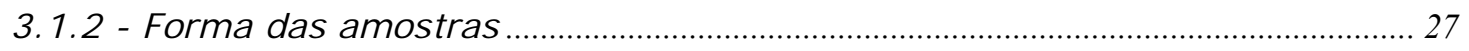

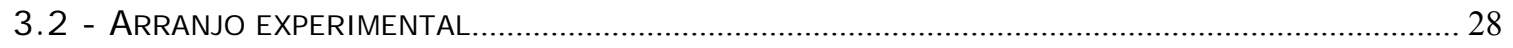

3.3 - INTENSIDADE ESPALHADA PELA AMOSTRA: CORREÇÃO POR CONTRIBUIÇÕES ESPÚRIAS .......... 30

3.4 - CÁlCUlo TEÓRICO DA Componente ESPALhadA PELA AMOSTRA ........................................... 34

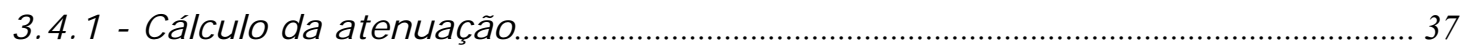

3.4.2 - Cálculo da correção por área de irradiação constante (correção da

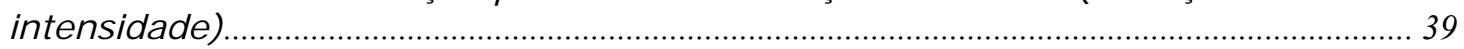

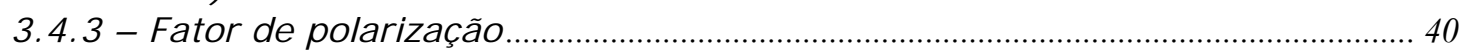

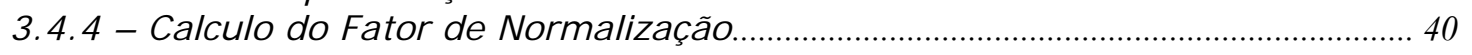

CAPÍ TULO 4 - RESULTADOS E DISCUSSÕES ................................................................. 43

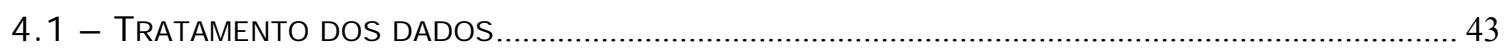

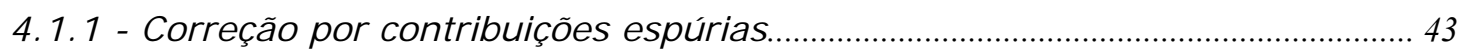

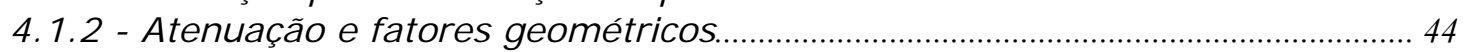

4.1 .3 - Correção por área de irradiação constante ......................................................... 45

4.1.4 - Correção por polarização............................................................................................... 45

4.1 .5 - Aplicação das correções e avaliação do procedimento experimental........... 46

4.2 - APRESENTAÇÃO DOS PERFIS DE ESPALHAMENTO E SUA COMPARAÇÃO COM A ANÁLI SE HISTOLÓGI CA DAS LAMI NAS E OS DADOS ENCONTRADOS NA

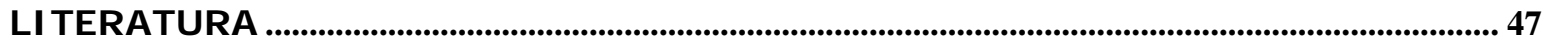

4.2.1 - Amostras de tecidos mamário medidas.................................................................... 47

4.2.2 - Perfil de espalhamento obtidos das medidas das amostras de tecido

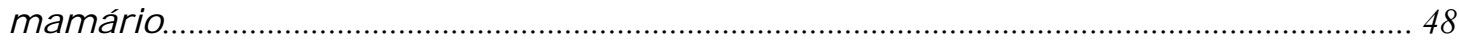

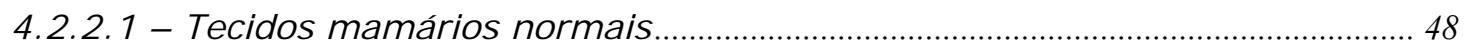

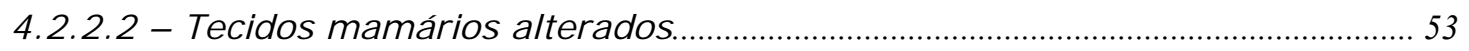

4.2.3 - Comparação dos perfis de espalhamento obtidos com os dados

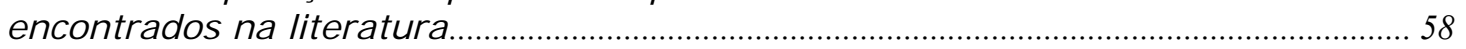


4.2.4 - Potencialidades dos perfis de espalhamento como ferramenta para diagnóstico.

4.3 - APRESENTAÇÃO DOS DADOS ESTATÍSTICOS DE CARACTERIZAÇÃO DOS TECIDOS .......................... 62

4.3.1 - Modelo de diagnóstico utilizando variáveis simplificadas ..................................62 62

4.3.2 - Modelo de diagnóstico utilizando análise de discriminante................................ 65

\section{CAPÍ TULO 5 - CONCLUSÕES E PERSPECTI VAS}

5.1 - SOBRE O MÉTODO DE OBTENÇÃO DOS PERFIS DE ESPALHAMENTO DE AMOSTRAS 69

5.2 - DOS RESULTADOS OBTIDOS PARA AS MEDIDAS DOS PERFIS DE ESPALHAMENTO DE TECIDOS MAMÁRIOS .70

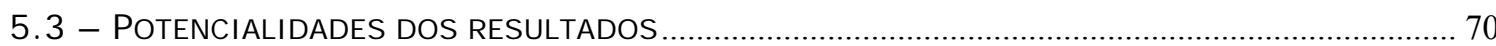

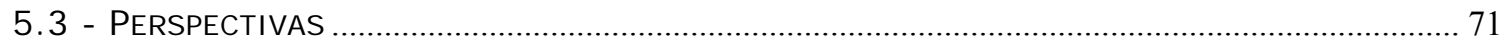

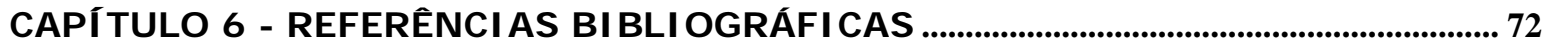




\section{ÍNDICE DE FIGURAS}

FI GURA 2.1: DIAGRAMA QUE ILUSTRA A FORMAÇÃO DA IMAGEM RADIOGRÁFI CA CONVENCIONAL CONSIDERANDO A RADIAÇÃO TRANSMITIDA PRIMÁRIA E ESPALHADA. (A) PACIENTE; (B) INTENSIDADE DA RADIAÇÃO TRANSMITIDA - B1 SÓ ESPALHAMENTO E B2 TOTAL; (C) IMAGEM RADIOGRÁFICA.

FIgURA 2.2: SEÇÃO DE CHOQUE DIFERENCIAL THOMSON E COMPTON EM FUNÇÃO DO ÂNGULO DE ESPALHAMENTO...

FIGURA 2.3: FATOR DE FORMA $F(X, Z)$ E FUNÇÃO DE ESPALHAMENTO INCOERENTE $S(X, Z)$ PARA O

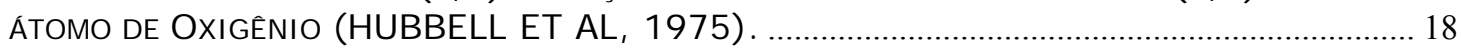

FI GURA 2.4: SEÇÃO DE CHOQUE DIFERENCI AL PARA O ESPALHAMENTO RAYLEIGH E COMPTON ATÔMICO PARA O ÁTOMO DE OXIGÊNIO PARA FÓTONS DE 17,44 KEV.

URA 2.5: FATOR DE FORMA E FUNÇÃO DE ESPALHAMENTO INCOERENTE DA MOLÉCULA DE $\mathrm{H}_{2} \mathrm{O}$. $\mathrm{F}_{\text {MOL }}(\mathrm{X})$ FOI OBTIDO UTILIZANDO DISTRIBUIÇÃO DE DENSIDADE ELETRÔNICA. $F_{m o l}^{M A I}(x) \mathrm{E}$ $S_{m o l}^{M A I}(x)$ FORAM OBTIDOS ATRAVÉS DO MODELO ATÔMICO INDEPENDENTE (MORIN, 1982) ....... 21

FI GURA 2.6: SEÇÃO DE CHOQUE DIFERENCIAL MOLECULAR EM 17,44 KEV. AS CURVAS FORAM OBTIDAS UTILIZANDO: (I) $\mathrm{F}_{\text {MOL }}(\mathrm{X})$, (II) $F_{m o l}^{M A I}(x)$ E (III) $S_{m o l}^{M A I}(x)$. 22

FI GURA 2.7: SEÇÃO DE CHOQUE DIFERENCIAL ELÁSTICA PARA (I) ÁGUA LÍQUIDA A 20C (MORIN,1982), (II) MOLÉCULA DE ÁGUA (MAI) E (III) SEÇÃO DE CHOQUE DIFERENCIAL

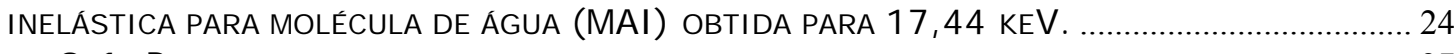

FI GURA 3.1: PORTA-AMOSTRA UTILIZADO NAS MEDIDAS............................................................ 27

FI gURA 3.2: ARRANJ O EXPERI MENTAL PARA AS MEDIDAS DE DIFRAÇÃO DE RAIOS-X........................ 28

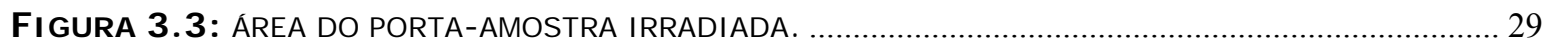

FI GURA 3.4: (A) REPRESENTAÇÃO ESQUEMÁTICA DO ARRANJ O EXPERIMENTAL UTI LIZADO PARA MEDIDA DAS AMOSTRAS DE TECIDO. (B) CONTRIBUIÇÃO DE CADA PARTE DO ARRANJ O AO ESPALHAMENTO.

FI GURA 3.5: VOLUME IRRADIADO QUE É VISTO PELO DETECTOR: (A) PARA ÂNGULOS DE DETECÇÃO

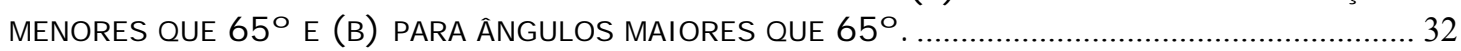

FI GURA 3.6: ARRANJ O EXPERIMENTAL UTILIZADO PARA MEDIDA DO ESPALHAMENTO ............................ 34

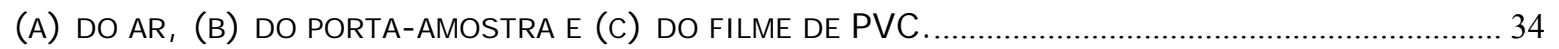

FIGURA 3.7: GEOMETRIA DE ESPALHAMENTO POR REFLEXÃO UTILIZADA. ............................................ 34

FI GURA 3.8: (A) VOLUME ESPALHADO DETECTADO, (B) LIMITES DE INTEGRAÇÃO............................. 37

FI GURA 4.1: MEDIDA EXPERIMENTAL DAS CONTRIBUIÇÕES ESPÚRIAS, REPRESENTADAS DE DUAS FORMAS:

(A) ESCALA LINEAR E (B) ESCALA LOGARÍTMICA.

Figura 4.2: ATENUAÇÃO PARA UMA AMOSTRA dE ÁGUA: (A) CURVA TEÓRICA E (B) CURVA OBTIDA POR MÉTODOS NUMÉRICOS.

FI GURA 4.3: VARIAÇÃO DA INTENSI DADE DO FEIXE INCI DENTE EXPERI MENTALMENTE. ...................... 45

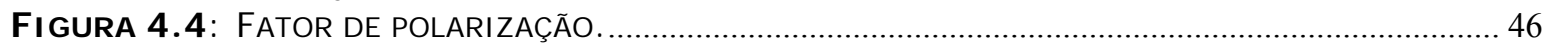

FI GURA 4.5: (A) PERFIL DE ESPALHAMENTO DA ÁGUA OBTIDO EXPERIMENTALMENTE COMPARADO A SEÇÃO DE CHOQUE DIFERENCIAL OBTIDA ATRAVÉS DOS FATORES DE FORMA OBTIDOS POR MORIN (MORIN, 1982); (B) DIFERENÇA RELATIVA ENTRE AS CURVAS DA FIGURA (A) . ........................47

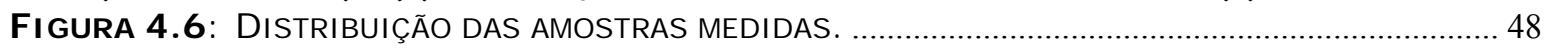

FI GURA 4.7: FOTO DE UMA LÂMINA DE TECIDO MAMÁRI O NORMAL. .................................................. 49

FI GURA 4.8: (A) PERFIL DE ESPALHAMENTO DE UM CASO TíPICO DE TECIDO NORMAL ADI POSO E A MÉDIA DOS TECIDOS MEDIDOS E (B) LÂMINA HISTOLÓGICA REPRESENTATIVA DE UM TECIDO ADIPOSO. CADA DEMARCAÇÃO FECHADA CORRESPONDE A UM ADIPÓCITO QUE CONTÉM INÚMEROS TRIGLICERÍDEOS.

FI GURA 4.9: (A) PERFIL DE ESPALHAMENTO MÉDIO DE UM TECIDO NORMAL GLANDULAR E (B) LÂMINA HISTOLÓGICA REPRESENTATIVA DE UM TECIDO FIBRO-GLANDULAR. O TECIDO VERMELHO CLARO REPRESENTA A PARTE FIBROSA E O TECIDO ESCURO A PARTE FORMADA POR ÁCINOS. 
FI GURA 4.10: (A) PERFIL DE ESPALHAMENTO COM PICO ADIPOSO E FIBRO-GLANDULAR, E (B) LÂMINA HISTOLÓGICA REPRESENTATIVA DA MISTURA DO TECIDO (APROXIMADAMENTE 80\% FIBROGLANDULAR E 20\% ADIPOSO).

FI GURA 4.11: (A) PERFIL DE ESPALHAMENTO MÉDIO, TÍPICO E UM CASO PARTICULAR DE FIBROADENOMA; (B) LÂMINA HISTOLÓGICA DA AMOSTRA 02; (C) LÂMINA HISTOLÓGICA DE UM CASO TÍPICO DE FIBROADENOMA (AMOSTRA 01).

FI gURA 4.12: (A) LÓBULOS E ESTROMA EM REGIÕES BEM DEFINIDAS (B) OS ÁCINOS E O ESTROMA SE MISTURAM.

FI GURA 4.13: (A) PERFIL DE ESPALHAMENTO MÉDI O OBTIDO PARA CADA GRAU DE ALTERAÇÃO DOS CARCINOMAS DUCTAIS INFILTRANTES (CDI, CDII E CDIII) E PARA A MÉDIA DE TODOS ELES; (B) E (C) FOTOS DAS LÂMINAS TíPICAS DAS AMOSTRAS DE CDI, (D) E (E) CDII, (F) E (G) CDIII. 57

FI GURA 4.14: PERFIL DE ESPALHAMENTO DO CM.

FI GURA 4.15: COMPARAÇÃO DOS RESULTADOS OBTIDOS NESSE TRABALHO COM OS APRESENTADOS NA LITERATURA: (A) TECIDO ADIPOSO, (B) GLANDULAR E (C) CANCEROSO.

FI GURA 4.16: (A) PERFIL DE ESPALHAMENTO MÉDIO PARA CADA TIPO DE TECIDO E (B) DIFERENÇA RELATIVA ENTRE OS TECIDOS ALTERADOS E O TECIDO NORMAL.

FI GURA 4.17: I NTERVALOS DE CONFIANÇA CONSTRUÍDOS PARA $\alpha=0,05$.

FI GURA 4.18: COORDENADAS DAS AMOSTRAS NO ESPAÇO $Z_{1} \times Z_{2}$. 


\section{ÍNDICE DE TABELAS}

TABELA 4.1: COMPARAÇÃO DOS PARÂMETROS QUE CARACTERIZAM OS PERFIS DE ESPALHAMENTO:

POSIÇÃO DO PICO, INTENSIDADE, LARGURA A MEIA ALTURA (LMA).

Tabela 4.2: TeSte de KRUSKal-Wallis Para as VARIÁVEIS P1, P2, I1, I2, LMA, E I2/I1...... 63 


\section{Capítulo 1 - Introdução}

O fenômeno de espalhamento de fótons tornou-se evidente desde o início dos estudos da interação da radiação com a matéria (COMPTON, 1923). Quando um fóton interage com a matéria desviando de sua trajetória inicial de modo que ele não sofra variação na sua energia temos o chamado espalhamento elástico ou coerente (JOHNS E CUNNINGHAM, 1983). Por outro lado, se o fóton perde energia no processo de interação temos o chamado espalhamento inelástico e incoerente (JOHNS E CUNNINGHAM, 1983).

Na radiologia, a técnica de obtenção de imagens radiográficas é baseada no uso das diferenças de coeficientes de atenuação linear dos diversos tipos de tecidos e materiais, detectando corpos de diferentes densidades e formas em um dado material. A radiação transmitida pelo objeto irá impressionar um receptor de imagem (como um filme radiográfico convencional) gerando um padrão de contraste (JOHNS E CUNNINGHAM, 1983). A ocorrência de efeitos de espalhamento (inelástico e elástico) gera uma degradação do contraste (REISS, 1963), já que ele adiciona um fundo quase constante no filme.

Considerada até hoje a mamografia técnica mais precisa de detecção de microcalcificações em sua fase inicial e a degradação do contraste é um ponto crítico para o diagnóstico (KOCH, 1996). Com o objetivo de explorar e controlar o efeito da radiação espalhada, diversos investimentos em pesquisas têm sido realizados (POLETTI, 1997-a, 1997-b; STRID, 1976).

O conceito de considerar o espalhamento como uma desvantagem vem mudando ultimamente, devido a dois fatores importantes (SPELLER, 1999; KIDANE ET AL, 1999; POLETTI ET AL 2002a, 2002b): (i) os fótons espalhados carregam informação sobre a 
estrutura presente no tecidos do paciente, informação que não é considerada em radiografia convencional, (ii) na maioria das energias usadas nas aplicações médicas, a interação mais provável é o espalhamento (elástico + inelástico). Estes fatos motivaram a se pesquisar as propriedades de espalhamento dos diferentes tecidos, tornando-se necessário à obtenção de medidas precisas dos perfis de espalhamento dos diferentes tecidos humanos (POLETTI ET $A L, 2004)$.

A distribuição do número de fótons espalhados em função do ângulo é denominada de perfil de espalhamento, sendo esta distribuição decorrente dos efeitos de interferência devido ao átomo, molécula ou à estrutura coletiva do material. Os fenômenos de espalhamento devido à estrutura foram amplamente estudados para sistemas altamente ordenados, tais como materiais cristalinos (Espalhamento Bragg). Mas também são importantes para sólidos amorfos, líquidos e alguns gases onde ocorre certo grau de ordenamento de curto alcance. Esses efeitos de interferência atômica e molecular causam na distribuição angular de intensidade espalhada um único e característico perfil de espalhamento (JAMES, 1962). Cada material tem seu próprio perfil, o qual pode ser calculado se forem conhecidos os parâmetros estruturais (distribuição espacial de carga, distância entre átomos, etc.). Como estes parâmetros são, em geral, desconhecidos a priori, o perfil de espalhamento deve ser medido experimentalmente (KIDANE, 1999; POLETTI, 2001 e 2002).

Existem alguns dados publicados na literatura sobre perfil de espalhamento em tecido animais e materiais equivalentes (KOSANETZKY ET AL, 1987; TARTARI ET AL; BRADLEY ET AL, 1989; PEPLOWS E VERGHESE, 1998) como também para tecidos mamários humanos (EVANS ET AL, 1990; KIDANE ET AL, 1999; SPELLER, 1999; POLETTI ET AL, 2002-a, 2002-b, 2004; FERNÁNDEZ ET AL, 2002). No entanto, existe 
um uso de técnicas inapropriadas para metodologia de medida e procedimentos de correção dos dados. Este trabalho, além de acrescentar novos dados à literatura, se propõe a:

(i) aprimorar e desenvolver novas montagens experimentais, utilizando difractômetros comerciais, e procedimentos de correções, que permitam a obtenção de medidas precisas dos perfis de espalhamento dos diferentes tecidos mamários;

(ii) realizar medidas experimentais dos perfis de espalhamento de tecidos mamários normais e cancerosos e correlacioná-las com as fotos microscópicas das lâminas histológicas;

(iii) estudar a influência dos perfis de espalhamento em mamografia como uma ferramenta útil para caracterização patológica das anomalias de mamas.

A divisão dos capítulos obedece à seguinte seqüência:

No capítulo 2, será apresentado o fundamento deste trabalho, começando por uma breve revisão histórica do papel do espalhamento na radiologia, vantagens e desvantagens. Também será apresentada uma breve revisão bibliográfica dos dados publicados sobre perfis de espalhamento, seções de choque e fatores de forma de tecidos biológicos e materiais equivalentes. Posteriormente, serão apresentadas as abordagens para descrever a seção de choque diferencial para o espalhamento de fótons em diversos sistemas, partindo do caso mais simples, o espalhamento de fótons por um elétron livre, até o caso que envolve um material amorfo composto por várias moléculas, sendo este último o mais aproximado para descrever espalhamento por tecidos biológicos.

No capítulo 3, serão apresentados os tecidos estudados neste trabalho, a configuração do arranjo experimental utilizado, as correções por contribuições espúrias e por efeitos geométricos realizadas para as medidas e, finalmente, a obtenção da seção de choque diferencial de espalhamento para os tecidos medidos. 
No capítulo 4, descreveremos os resultados obtidos para os procedimentos de correção e para as medidas dos perfis de espalhamento dos tecidos mamários, fazendo uma comparação com as lâminas histológicas destes tecidos e com os dados anteriormente publicados na literatura; ainda apresentaremos de maneira resumida um estudo estatístico realizado com os perfis de espalhamento obtidos nesse trabalho.

O capítulo 5 será dedicado às conclusões e perspectivas futuras do trabalho. 


\section{CAPÍTULO 2 - Fundamentos Teóricos}

\section{1 - Histórico e Revisão Bibliográfica}

Nesta seção será apresentada uma breve revisão histórica do papel do espalhamento, considerando suas vantagens e desvantagens na radiologia. Também será apresentada uma breve revisão bibliográfica dos dados publicados sobre perfis de espalhamento, seções de choque, fatores de forma de tecidos biológicos e materiais equivalentes.

\subsection{1 - O espalhamento no radiodagnóstico - desvantagem}

As imagens radiográficas convencionais são obtidas através das diferenças de coeficientes de atenuação linear dos diversos tipos de tecidos e materiais, detectando corpos de diferentes densidades e formas em um dado material. A radiação transmitida, composta da radiação primária e espalhada, impressiona um receptor de imagem, geralmente uma combinação tela-filme, gerando um padrão de contraste no filme (JOHNS E CUNNINGHAM, 1983; SPRAWLS, 1995).

A figura 2.1 mostra como o espalhamento atua na formação da imagem, adicionando à intensidade um fundo quase constante ao longo da distribuição espacial (curva B1 sobre a figura 2.1-b). Este fundo é decorrente da interpretação que o receptor faz, não diferenciando fótons espalhados daqueles transmitidos sem nenhuma interação. Desta forma, fótons espalhados contribuem para a redução do contraste na imagem radiológica e caso não sejam reduzidos, podem diminuir o contraste em até 60\% (BARNES, 1991). Em 
particular, na mamografia esta degradação do contraste torna-se crítica (POLETTI, 1997b).

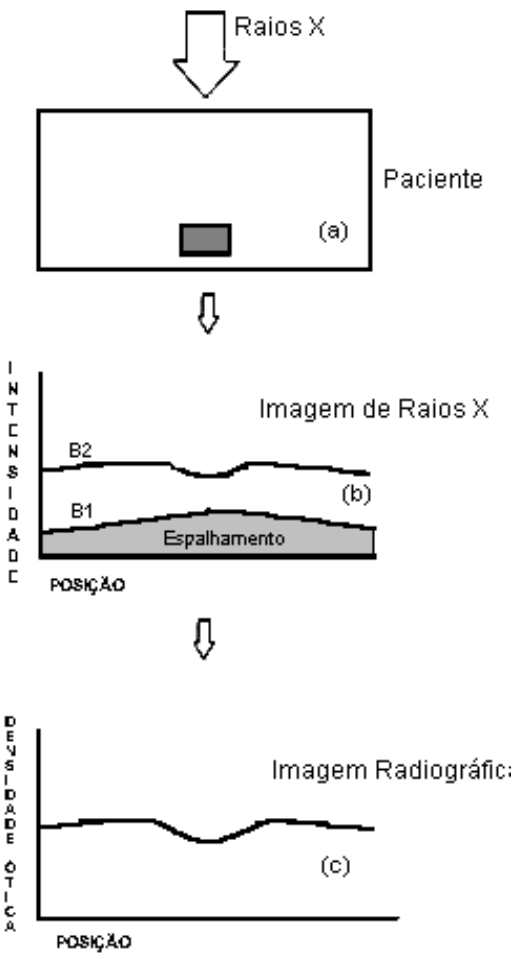

Figura 2.1: Diagrama que ilustra a formação da imagem radiográfica convencional considerando a radiação transmitida primária e espalhada. (a) paciente; (b) intensidade da radiação transmitida - B1 só espalhamento e B2 total; (c) imagem radiográfica.

Diversos investimentos em pesquisas têm como objetivo explorar e controlar o efeito da radiação espalhada, de forma a permitir que a imagem contenha informações mais claras e precisas (POLETTI, 1997a, 1997b; STRID, 1976; SORENSON E FLOCH, 1985; BARNES, 1979 e 1994). 


\subsection{2 - O Espalhamento como ferramenta para a caracterização de tecidos - vantagem}

O conceito de considerar o espalhamento como uma desvantagem vem mudando ultimamente (SPELLER E HORROCKS, 1991). Estudos recentes mostram que experiências de espalhamento de raios X (espalhamento a baixo ângulo e difração) fornecem informações detalhadas sobre as estruturas que compõe os tecidos, fornecendo meios alternativos para distinguir patologias (KIDANE ET AL, 1999; POLETTI ET AL 2001, 2002-a, 2002-b).

Estes fatos levaram a se pesquisar as propriedades de espalhamento dos diferentes tecidos, tornando-se necessário à obtenção de medidas precisas dos perfis de espalhamento dos diferentes tecidos humanos (POLETTI ET AL, 2004).

Neste tópico será apresentada uma revisão bibliográfica com os principais trabalhos publicados sobre o estudo do espalhamento por tecidos biológicos, com ênfase em tecidos mamários.

A água é o material equivalente mais utilizado para simular tecidos biológicos, uma vez que é o elemento mais abundante na composição da maior parte dos tecidos (cerca de 65\%). Narten e Levy (NARTEN E LEVY, 1971) determinaram as funções de estrutura e de correlação molecular para água líquida a diferentes temperaturas a partir de dados de difração de raios-X obtidos anteriormente (NARTEN, 1970) com um tubo com anodo de Molibdênio $(\mathrm{K} \alpha=17,44 \mathrm{keV})$. Morin (MORIN, 1982) tabulou o fator de forma para água líquida a diferentes temperaturas a partir dos dados das funções de estrutura obtidos por Narten e Levy. Johns e Yaffe (JOHNS E YAFFE, 1983) utilizaram os dados de difração de Narten para calcular a seção de choque da água líquida. 
Kosanetzky et al (KOSANETZKY ET AL, 1987) utilizando um difractômetro de raios-X com anodo de $\mathrm{Co}(\mathrm{K} \alpha=6.935 \mathrm{keV})$, mediram os perfis de espalhamento da água, vários materiais plásticos equivalentes e alguns tecidos biológicos extraídos de animais suínos, tendo observado diferenças entre os perfis de espalhamento dos tecidos de diferentes órgãos.

Bradley et al (BRADLEY ET AL, 1989) mediram a seção de choque à baixos ângulos de espalhamento $\left(2^{\circ}\right.$ a $\left.10^{\circ}\right)$ da água, nylon e lucite, utilizando uma fonte monoenergética de raios gama de ${ }^{241} \mathrm{Am}(59,54 \mathrm{keV})$ e apresentaram um método para correção dos dados experimentais. Os resultados obtidos mostram a existência de picos de espalhamento que ocorrem em diferentes posições angulares para cada material.

Evans et al (EVANS ET AL, 1991) mediram o perfil de espalhamento de tecidos mamários (adiposo, fibroglandular, tumor benigno, carcinoma e fibroadenoma), sangue e alguns materiais equivalentes, utilizando um feixe polienergético produzido por um tubo de raios-X como anodo de cobre (energia média efetiva de $46 \mathrm{keV}$ ). Tabularam as posições do pico principal de espalhamento e o valor da largura à meia altura de cada tipo de amostra, observando grandes diferenças entre os perfis dos tecidos adiposo e fibro-glandular, além de pequenas diferenças entre carcinomas e tecido fibroglandular.

Tartari et al (TARTARI ET $A L, 1997-a)$ mediram a seção de choque diferencial molecular de espalhamento coerente de gordura proveniente de suínos e polimetilmetacrilato (PMMA) utilizando um tubo de raios-X com anodo de cobre $(\mathrm{K} \alpha=8,04 \mathrm{keV})$. Tabularam o fator de forma a partir dos dados obtidos, considerando os materiais como sendo monomoleculares e mostraram que o PMMA não é um material adequado para simular o espalhamento de tecido adiposo. Também mostraram fatores de 
correção relevantes que devem ser aplicados aos dados experimentais (TARTARI ET AL, 1998) e um estudo da validade da aproximação do Modelo Atômico Independente (TARTARI ET $A L, 1997-\mathrm{b})$.

Peplows e Verghese (PEPLOWS E VERGHESE, 1998) tabularam o fator de forma molecular do espalhamento coerente de materiais plásticos, tecidos biológicos de animais e tecido mamário humano. Para isso utilizaram radiação síncroton monoenergética de $8 \mathrm{keV}$ e $20 \mathrm{keV}$ e apresentaram um cálculo para obter o fator de forma através das distribuições medidas utilizando o método de Monte Carlo.

Kidane et al (KIDANE ET AL, 1999) mediram o perfil de espalhamento para tecidos mamários normais e neoplásicos através da técnica de EDXRD com um tubo de raios-X com anodo de tungstênio $(\mathrm{K} \alpha=58,86 \mathrm{keV})$. A composição histológica de cada tecido foi determinada, e os perfis de espalhamento de diferentes tipos de tecidos comparados. Os resultados mostraram que há diferenças notáveis entre os perfis de espalhamento de tecidos normais e neoplásicos. As posições e altura dos picos principais de espalhamento foram tabuladas.

Speller (SPELLER, 1999) analisou o espalhamento coerente de tecidos mamários normais e neoplásicos através da técnica de espalhamento a baixos ângulos (LAXS), mostrando que a principal diferença dos perfis de espalhamento entre os tipos de tecidos deve-se à quantidade de células adiposas presentes.

Tartari (TARTARI, 1999) mediu a seção de choque diferencial molecular de tecido ósseo e comparou os resultados obtidos anteriormente para gordura e PMMA (TARTARI ET AL, 1997-a) com resultados de outros autores. Posteriormente Tartari et al (TARTARI $E T A L, 2000)$ mostrou que pode-se obter o fator de forma de tecidos biológicos hipotéticos 
através da combinação linear dos fatores de forma de alguns componentes básicos, como gordura, colágeno, componentes minerais de tecidos ósseos e água, utilizando o método de Monte Carlo. Em 2002, Tartari et al (TARTARI ET AL, 2002) tabularam os fatores de forma moleculares para gordura, água, matriz óssea e componente mineral ósseo, e obtiveram através de simulações de Monte Carlo os fatores de forma para tecido adiposo e muscular, comparando-os com resultados obtidos experimentalmente por outros autores.

Poletti et al (POLETTI ET AL, 2002-a) mediram o coeficiente de espalhamento diferencial linear, que é proporcional à seção de choque, de tecidos mamários normais e neoplásicos, e materiais equivalentes utilizando tubos de raios-X com anodo de Cobalto $(\mathrm{K} \alpha=6,93 \mathrm{keV})$ e de Molibdênio $(\mathrm{K} \alpha=17,44 \mathrm{keV})$. Os resultados mostravam diferenças consideráveis entre os tecidos mamários e os materiais equivalentes a baixos ângulos. Diferenças entre os tecidos normais e neoplásicos também foram observadas. Posteriormente, apresentaram novas comparações entre tecidos mamários (adiposo e glandular) e materiais equivalentes (POLETTI ET AL, 2002-b), encontrando novamente diferenças entre eles. Obtiveram também o fator de forma e o coeficiente de atenuação linear para esses tecidos e materiais e apresentaram parâmetros para caracterizar seus perfis de espalhamento, tais como posição e altura do pico e largura à meia altura.

Poletti et al (POLETTI ET AL, 2002-c) também apresentaram um método de correção de dados experimentais para se obter a seção de choque diferencial de espalhamento de materiais amorfos, considerando efeitos de polarização do feixe, múltiplo espalhamento, atenuação, geometria, dentre outros fatores. Em 2004 Poletti et al (POLETTI ET AL, 2004) apresentaram novas comparações entre tecidos mamários, muscular e materiais equivalentes. Os resultados mostraram que na região de $x<0,4 \AA^{-1}$ os 
perfis de espalhamento de tecidos humanos e materiais equivalentes apresentam diferenças significativas.

Fernández et al (FERNÁNDEZ ET AL, 2002) obtiveram o perfil de espalhamento para tecidos mamários normais e neoplásicos a baixos ângulos utilizando radiação síncroton monoenergética de $12,5 \mathrm{keV}$. Também obtiveram o perfil de espalhamento para fibras de colágeno. Foi observado que a quantidade de colágeno é maior em tecidos normais e tumores benignos, enquanto tumores malignos e áreas com necrose são pobres em colágeno. O perfil de espalhamento dos tecidos foi comparado com uma análise histológica, e as diferenças de intensidade encontradas foram atribuídas ao fato de o tecido invadido pelo tumor possuir mais centros espalhadores que o tecido normal.

Johns e Wismayer (JOHNS E WISMAYER, 2004) obtiveram os fatores de forma de espalhamento para materiais amorfos utilizando dois difractômetros comerciais em diferentes energias: um tubo de raios- $\mathrm{X}$ com anodo de $\mathrm{Cu}(\mathrm{K} \alpha=8,04 \mathrm{keV})$ e outro com anodo de $\mathrm{Co}(\mathrm{K} \alpha=6,93 \mathrm{keV})$. Os materiais analisados foram água, PMMA, nylon, e tecido muscular animal e os resultados obtidos foram comparados com os de outros autores, mostrando que é possível medir os perfis de espalhamento de tecidos amorfos utilizando difractômetros comerciais, apesar de os resultados encontrados divergirem em até $20 \%$ de outros autores.

Vários trabalhos sobre o espalhamento de raios-X por tecidos mamários já foram realizados por diversos autores. Os resultados obtidos apontam para a possibilidade de se caracterizar um tecido através de seu perfil de espalhamento devido à sua composição histológica. Neste aspecto, o presente trabalho vem acrescentar novos dados à literatura, fazendo o uso de um difractômetro comercial e de uma geometria de reflexão, recursos 
pouco explorados nos trabalhos anteriores. Grande parte dos trabalhos existentes utiliza configuração própria e geometria por transmissão de fótons. Uma outra proposta deste trabalho consiste em fazer a comparação dos perfis de espalhamento com a análise de lâminas microscópicas dos tecidos medidos, a fim de verificar se estas podem trazer informações correlatas com o perfil de espalhamento medido.

\section{2 - Interação da Radiação com a Matéria}

Os principais fenômenos de interação da radiação com a matéria considerando a faixa de energia utilizada em radiodiagnóstico $(E<100 \mathrm{keV})$ são o efeito fotoelétrico e os espalhamentos elástico e inelástico. Em particular, para fótons com energia utilizada em mamografia $(17,44 \mathrm{keV})$ numa amostra de tecido mamário, 80,7\% do total de interações ocorrem por efeito fotoelétrico, $8,5 \%$ para o espalhamento elástico e 10,8\% para o espalhamento inelástico (JOHNS E CUNNINGHAM, 1983).

Nesta seção serão apresentadas as abordagens para descrever a seção de choque diferencial para o espalhamento de fótons em diversos sistemas, partindo do caso mais simples, que é o espalhamento de fótons por um elétron livre, até o caso que envolve um material amorfo, composto por várias moléculas, sendo este último o mais aproximado para descrever espalhamento por tecidos biológicos. 


\section{Espalhamento Elástico e Inelástico}

Quando um fóton interage com a matéria se desviando da sua trajetória inicial de modo que ele não sofra variação na sua energia temos o chamado espalhamento elástico ou coerente. O campo elétrico da onda eletromagnética, com comprimento de onda $\lambda$, associada a esse fóton dá origem a uma vibração dos elétrons presentes na matéria. Devido a essa aceleração os elétrons emitem uma radiação de mesmo comprimento de onda $\lambda$ que a radiação incidente (JOHNS E CUNNINGHAN, 1983).

Por outro lado, se os elétrons do meio absorvem, em forma de energia cinética, parte da energia do fóton incidente e este se desvia de sua trajetória inicial, temos o chamado espalhamento inelástico e incoerente. O processo de espalhamento inelástico foi tratado inicialmente por Compton (COMPTON, 1923) que considerou a radiação como pacotes de onda quantizados com energia $h v$. Por isso, esse processo recebe o nome de espalhamento Compton (JOHNS E CUNNINGHAN, 1983).

\subsection{1 - Espalhamento por elétron livre}

\section{(a) Elétron livre: Espalhamento Elástico}

Se o espalhamento elástico ocorre devido somente a um elétron livre ele recebe o nome de espalhamento Thomson, em homenagem ao primeiro cientista que obteve a seção de choque diferencial de espalhamento para um elétron (THOMSON, 1906). Thomson considerando um feixe de fótons não polarizado e apenas suposições de física clássica obteve a seguinte expressão 


$$
\left(\frac{d \sigma}{d \Omega}\right)_{T h}=\frac{r_{0}^{2}}{2}\left(1+\cos ^{2} \theta\right)
$$

onde $r_{0}=\frac{1}{4 \pi \varepsilon_{0}} \frac{e^{2}}{m_{0} c^{2}}=2.82 \times 10^{-15} \mathrm{~m}$ é o raio clássico do elétron e $\theta$ é o ângulo de espalhamento. A forma da seção de choque Thomson está representada na figura 2.2.

\section{(b) Elétron Livre: Espalhamento Inelástico ou Compton}

Se um fóton é espalhado por um elétron livre de forma que não ocorra conservação na energia deste fóton, a seção de choque de espalhamento diferencial é dada por:

$$
\left(\frac{d \sigma}{d \Omega}\right)_{K N}=\left(\frac{d \sigma}{d \Omega}\right)_{T h} F_{K N}=\left(\frac{d \sigma}{d \Omega}\right)_{T h}[1+\alpha(1-\cos \theta)]^{-2}\left\{1+\frac{\alpha^{2}(1-\cos \theta)^{2}}{[1+\alpha(1-\cos \theta)]\left(1+\cos ^{2} \theta\right)}\right\}
$$

onde $\alpha=h v / m_{0} c^{2}$

Essa expressão foi obtida por métodos de eletrodinâmica quântica por Klein e Nishina em 1928 (JOHNS E CUNNINGHAN, 1983). A forma de $\left(\frac{d \sigma}{d \Omega}\right)_{K N}$ para diferentes energias dos fótons incidentes está representada na figura 2.2. Para energia de $0 \mathrm{MeV}$, a seção de choque se reduz à expressão de $\left(\frac{d \sigma}{d \Omega}\right)_{T h}$ da equação (2.1). 


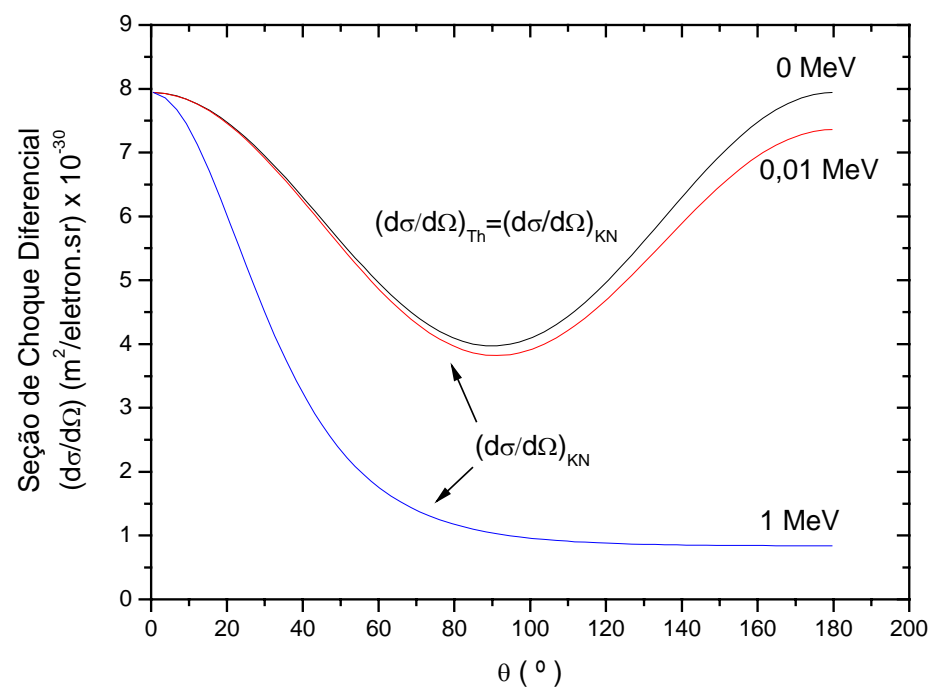

Figura 2.2: Seção de choque diferencial Thomson e Compton em função do ângulo de espalhamento.

\subsection{2. - Espalhamento por átomo livre}

\section{(a) Átomo Livre: Espalhamento Elástico}

O espalhamento elástico de fótons por um átomo livre, chamado espalhamento Rayleigh em homenagem ao cientista que o discutiu para a luz visível Lord Rayleigh (1881), ocorre quando os fótons incidentes têm sua energia conservada e sofrem variação de momento após o espalhamento pelos elétrons ligados ao átomo. As ondas espalhadas por cada elétron sofrem interferência construtiva devido à diferença de caminho ótico percorrido no átomo. A seção de choque diferencial pode ser expressa na forma

$$
\left(\frac{d \sigma}{d \Omega}\right)_{\text {Ray }}=[F(x, Z)]^{2}\left(\frac{d \sigma}{d \Omega}\right)_{T h}
$$


onde $x=\lambda^{-1} \operatorname{sen}(\theta / 2)$ é proporcional ao momento transferido $q$ na interação do fóton com o átomo e a relação entre $x$ e $q$ é dada por $x=20.607744 \hbar q$. $Z$ é o número atômico. $F(x, Z)$ é chamado fator de forma atômico. A partir desse ponto será usado $x$ para representar o momento transferido.

A função $F(x, Z)$ é a transformada de Fourier da distribuição de cargas do átomo (HUBBELL ET $A L, 1975)$. O fator de forma total do átomo pode ser decomposto na soma dos fatores de forma individuais de cada camada eletrônica do átomo (HUBBELL ET AL, 1975). O fator de forma $F(x, Z)$ está representado na figura 2.3 para o átomo de Oxigênio $(Z=8)$. A forma da seção de choque diferencial $\left(\frac{d \sigma}{d \Omega}\right)_{\text {Ray }}$ está representada na figura 2.4 para o mesmo átomo.

A partir da figura 2.3 pode-se notar que para baixos valores de momento transferido $x$, isto é $x \rightarrow 0, F(x, Z) \rightarrow Z$ (interferência construtiva). Para altos valores de $x(x \rightarrow \infty)$, $F(x, Z) \rightarrow 0$ (interferência destrutiva).

\section{(b) Átomo Livre: Espalhamento Inelástico}

O espalhamento inelástico num átomo (ou Compton atômico) pode ser descrito como uma aproximação análoga à realizada para o espalhamento Rayleigh. Definindo o fator $S(x, Z)$, também chamado de função do espalhamento inelástico, a seção de choque diferencial do efeito Compton atômico pode ser escrita:

$$
\left(\frac{d \sigma}{d \Omega}\right)_{C o m p}=S(x, Z)\left(\frac{d \sigma}{d \Omega}\right)_{K N}
$$


onde $\left(\frac{d \sigma}{d \Omega}\right)_{K N}$ é a seção de choque diferencial obtida para o elétron livre na equação (2.2). O fator $S(x, Z)$ é análogo ao fator de forma do espalhamento Rayleigh, e é usualmente calculado por tratamento não-relativístico. As figuras 2.3 e 2.4 mostram o comportamento de $S(x, Z)$ e $\left(\frac{d \sigma}{d \Omega}\right)_{\text {Comp }}$, respectivamente, para o átomo de Oxigênio.

Da figura 2.3 vê-se que se o momento transferido $x$ é muito baixo, ou seja, quando $x \rightarrow 0, S(x, Z) \rightarrow 0$ pelo fato de que a energia transferida pelo fóton ao atingir um elétron é menor que a energia de ligação do elétron ao átomo. Quando $x \rightarrow \infty$, o fóton possui momento alto o suficiente para arrancar qualquer um dos elétrons ligados ao átomo. Nesse caso a probabilidade de o fóton atingir um elétron do átomo será proporcional ao número de elétrons $Z$ no átomo e à seção de choque de Klein-Nishina da equação (2.2), ou seja $\left(\frac{d \sigma}{d \Omega}\right)_{\text {Comp }}=Z\left(\frac{d \sigma}{d \Omega}\right)_{K N}$. Comparando com a equação (2.4), pode-se ver então que $S(x, Z) \rightarrow Z$ quando $x \rightarrow \infty$ 


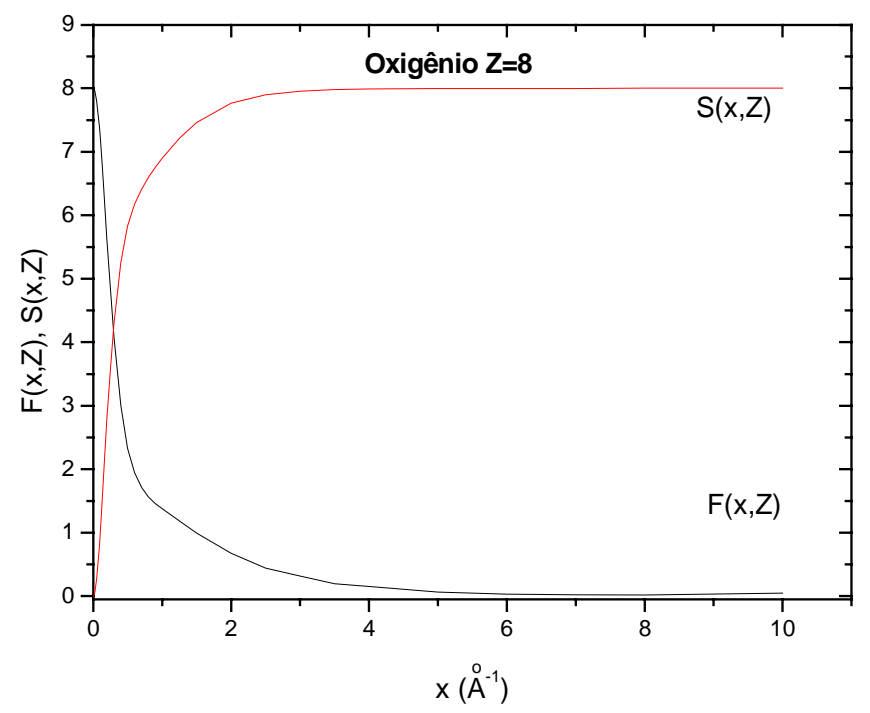

Figura 2.3: Fator de forma $F(x, Z)$ e função de espalhamento incoerente $S(x, Z)$ para o átomo de Oxigênio (HUBBELL ET AL, 1975).

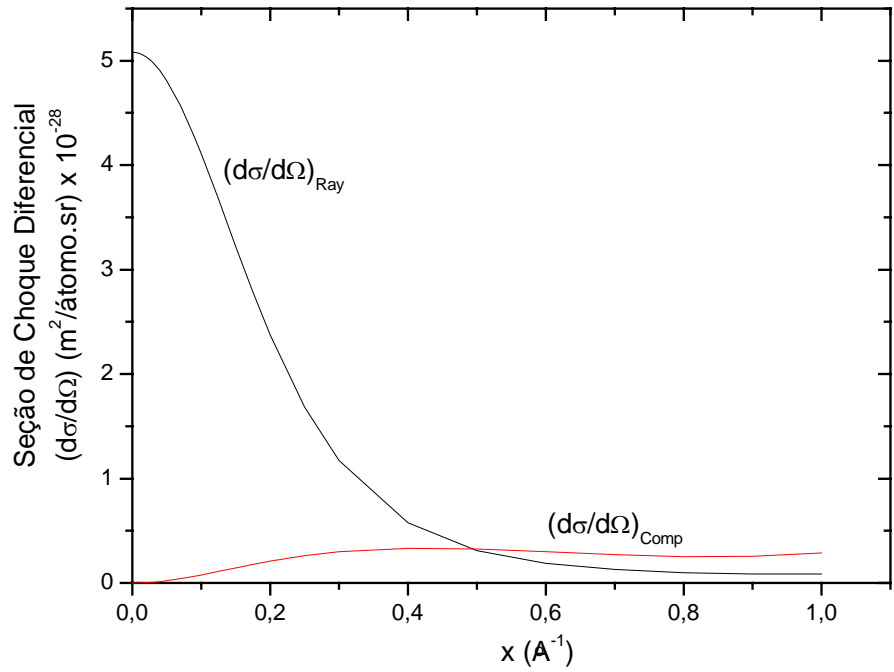

Figura 2.4: Seção de Choque Diferencial para o espalhamento Rayleigh e Compton atômico para o átomo de Oxigênio para fótons de $17,44 \mathrm{keV}$. 


\subsection{3 - Espalhamento por Molécula Livre}

\section{(a) Molécula Livre: Espalhamento Elástico}

Para determinar o espalhamento por uma molécula livre podem ser utilizadas três abordagens: A aproximação mais geral utiliza a distribuição de densidade eletrônica dentro da molécula (BLUM, 1971 apud NARTEN E LEVY, 1971). Outra aproximação possível requer o conhecimento das distâncias atômicas dentro da molécula (DEBYE, 1915 apud NARTEN E LEVY, 1971). Uma terceira aproximação, mais simples, supõe que o espalhamento por uma molécula livre é composto pelas contribuições independentes de cada átomo que a compõe. Essa última aproximação é também chamada Modelo Atômico Independente (MAI) (JAMES, 1962).

O Modelo Atômico Independente é a forma mais simples de se calcular o espalhamento de fótons por uma molécula livre. Neste caso o fator de forma molecular será determinado pela soma dos fatores de forma de cada átomo independentemente.

A seção de choque diferencial elástica para uma molécula livre é da forma:

$$
\left(\frac{d \sigma}{d \Omega}\right)_{\text {elas }}^{\text {mol }}=F_{m o l}^{2}(x)\left(\frac{d \sigma}{d \Omega}\right)_{T h}
$$

onde $F_{m o l}^{2}(x)$ é o fator de forma molecular, e pode ser obtido nas três aproximações antes mencionadas. No MAI temos duas maneiras de calcular o fator de forma molecular:

(i) Se o número de átomos for conhecido, $F_{m o l}^{2}(x)$ assume a forma:

$$
F_{\text {mol }}^{2}(x)=\sum n_{i} F_{i}^{2}(x)
$$


onde $F_{i}$ é o fator de forma de cada átomo e $n_{i}$ o número de átomos de cada elemento.

(ii) Se o número de átomos for desconhecido, $F_{m o l}^{2}(x)$ pode ser obtida pela fração de massa $w_{i}$ e pela massa atômica $A_{i}$ do átomo $i$ :

$$
F_{m o l}^{2}(x) / M=\sum\left(\frac{w_{i}}{A_{i}}\right) F_{i}^{2}(x)
$$

onde $M$ é o peso molecular (CHAN ET AL, 1983).

A figura 2.5 mostra o comportamento da função $F_{m o l}(x)$ para molécula de água utilizando a distribuição de densidade de carga eletrônica (primeira aproximação mencionada) (BLUM, 1971) e o modelo atômico independente (última aproximação mencionada) (HUBBELL ET AL, 1975). A seção de choque diferencial elástica para molécula de água está representada na figura 2.6 calculada a partir das duas aproximações de $F_{m o l}(x)$. Pode-se notar que as duas aproximações convergem para o mesmo valor quando $x>0,4 \mathrm{~A}^{-1}$.

\section{(b) Molécula Livre: Espalhamento Inelástico}

No espalhamento inelástico de uma molécula, assim como para um átomo, cada elétron contribui de forma independente para o espalhamento (JOHNS E YAFFE, 1983). A seção de choque pode então ser dada como

$$
\left(\frac{d \sigma}{d \Omega}\right)_{\text {inelas }}^{\text {mol }}=S_{m o l}(x)\left(\frac{d \sigma}{d \Omega}\right)_{K N}
$$


onde $S_{m o l}(x)$ é a função de espalhamento incoerente molecular, definida como $S_{m o l}(x)=\sum n_{i} S_{i}(x)$, se o número de átomos for conhecido. $S_{i}(x)$ é a função de espalhamento incoerente de cada átomo e $n_{i}$ o número de cada átomo na molécula (CHAN ET AL, 1983). Os valores de $S_{i}(x)$ estão tabulados em Hubbell et al (HUBBELL ET AL, 1975) corrigidos pelas energias de ligação dos elétrons.

Se o número de átomos for desconhecido, $S_{m o l}(x)$ também pode ser obtida à partir da fração de massa $w_{i}$ e da massa atômica $A_{i}$ do átomo $i$, através da expressão $S_{m o l}(x) / M=\sum\left(\frac{w_{i}}{A_{i}}\right) S_{i}(x)$, onde $M$ é o peso molecular.

A função de espalhamento incoerente molecular $S_{m o l}(x)$ está representada na figura 2.5, e a seção de choque diferencial inelástica molecular na figura 2.6, tendo sido obtidas utilizando o modelo atômico independente para água.

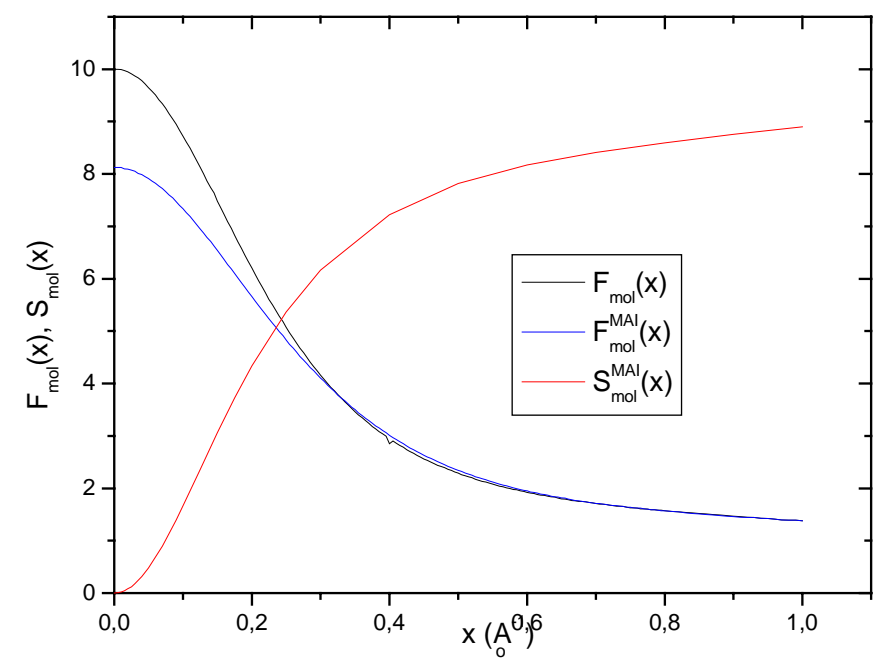

Figura 2.5: Fator de forma e função de espalhamento incoerente da molécula de $\mathrm{H}_{2} \mathrm{O} . F_{\text {mol }}(x)$ foi obtido utilizando distribuição de densidade eletrônica. $F_{m o l}^{M A I}(x)$ e $S_{m o l}^{M A I}(x)$ foram obtidos através do modelo atômico independente (MORIN, 1982). 


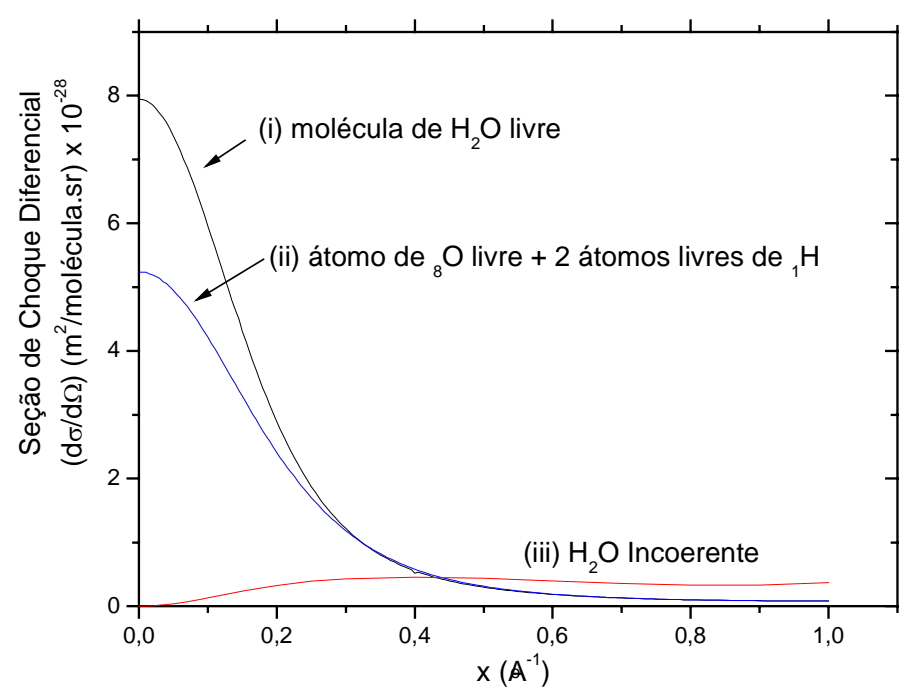

Figura 2.6: Seção de choque diferencial molecular em 17,44 keV. As curvas foram obtidas utilizando: (i) $F_{m o l}(x)$, (ii) $F_{m o l}^{M A I}(x)$ e (iii) $S_{m o l}^{M A I}(x)$.

\subsection{4 - Espalhamento por Conjunto de Moléculas}

\section{(a) Conjunto de Moléculas: Espalhamento Elástico}

A descrição do espalhamento por um conjunto de moléculas também pode ser obtida através da aproximação de fator de forma. A expressão para a seção de choque diferencial elástica por molécula é da forma:

$$
\left(\frac{d \sigma}{d \Omega}\right)_{\text {elas }}=I(x)\left(\frac{d \sigma}{d \Omega}\right)_{\text {elas }}^{\text {mol }}=F_{e q}^{2}(x)\left(\frac{d \sigma}{d \Omega}\right)_{T h}
$$


onde $I(x)$ é a função interferência, que leva em conta o grau de ordem da estrutura atômica (ou molecular), $\left(\frac{d \sigma}{d \Omega}\right)_{\text {elas }}^{\text {mol }}$ é a seção de choque para o espalhamento de uma molécula livre (eq.5). $F_{e q}(x)$ é o fator de forma equivalente que permite obter a seção de choque do conjunto de moléculas a partir da seção de choque Thomson na equação (2.1). I(x) assume a forma

$$
I(x)=1+\sum_{i} Y_{i} \frac{\operatorname{sen}\left(q r_{i}\right)}{q r_{i}}
$$

onde $Y_{i}$ leva em conta a diferença entre a densidade atômica média e a densidade de centros espalhadores em cada posição $r_{i}$ (POLETTI, 2001).

A figura 2.7 mostra a seção de choque elástica para água líquida a $20^{\circ} \mathrm{C}$ obtida a partir do fator de forma tabulado por Morin (MORIN, 1982). Observa-se que a função de interferência provoca oscilações na seção de choque do conjunto de moléculas. Tais oscilações ocorrem em torno da seção de choque da molécula livre calculada a partir do MAI, observando-se também a existência de interferência destrutiva para valores baixos de $x$. Este efeito é bem conhecido em estudos de difração por líquidos ou materiais amorfos (JAMES, 1962). Para valores de $x$ maiores as duas curvas convergem para os mesmos valores. 


\section{(b) Conjunto de Moléculas: Espalhamento Inelástico}

Uma vez que no espalhamento inelástico os comprimentos de onda dos fótons espalhados são diferentes entre si, não existe uma relação de interferência entre as várias moléculas que compõe o conjunto. Pode-se supor que cada átomo contribui de forma independente para o espalhamento (Modelo Atômico Independente). Assim a seção de choque por molécula será determinada da mesma forma como realizado anteriormente para a molécula livre

$$
\left(\frac{d \sigma}{d \Omega}\right)_{\text {inelas }}=S_{m o l}(x)\left(\frac{d \sigma}{d \Omega}\right)_{K N}
$$

$S_{m o l}(x)$ é a função de espalhamento incoerente molecular, definida na seção 2.2.3-a.

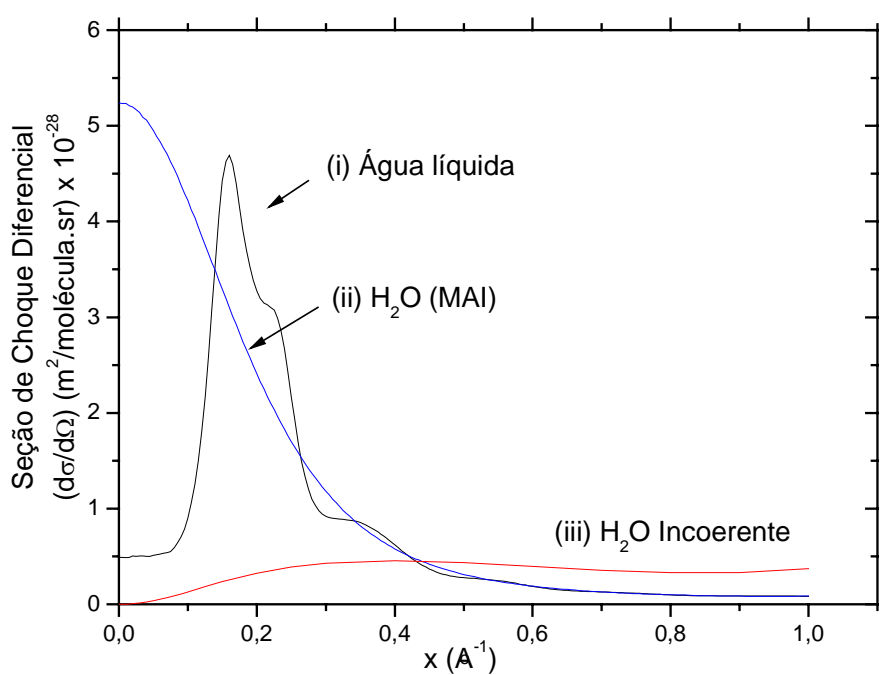

Figura 2.7: Seção de choque diferencial elástica para (i) água líquida a $20^{\circ} \mathrm{C}$ (MORIN,1982), (ii) molécula de água (MAI) e (iii) seção de choque diferencial inelástica para molécula de água (MAI) obtida para 17,44 keV. 


\subsection{5 - Abordagem teórica adotada}

Neste trabalho foi analisada a distribuição angular dos fótons espalhados (perfil de espalhamento) por tecidos mamários, que é governada pela seção de choque do conjunto de moléculas que compõe o tecido. Deve-se esperar, portanto, que este espalhamento seja descrito pelas equações (2.9) e (2.11), para o espalhamento elástico e inelástico, respectivamente.

A partir da figura 2.7 vê-se que o comportamento da seção de choque, e conseqüentemente do perfil de espalhamento, é uma função do parâmetro $x$. Para valores pequenos de $x$ a seção de choque apresenta uma dependência da distribuição espacial das estruturas (moléculas) que compõe as células do tecido. Para valores maiores de $x$ ela pode ser descrita pelo Modelo Atômico Independente, ou seja, os átomos que compõe o material espalham os fótons de forma independente uns dos outros. No intervalo de $x$ considerado neste trabalho espera-se observar padrões de interferência nos perfis de espalhamento dos tecidos. 


\section{CAPÍTULO 3 - Materiais e Método}

Neste capítulo serão apresentados os tecidos estudados neste trabalho, a configuração do arranjo experimental utilizada, as correções por contribuições espúrias, efeitos geométricos e atenuação realizadas para as medidas e finalmente, a obtenção da seção de choque diferencial de espalhamento (perfil de espalhamento).

\section{1 - Materiais Estudados}

\subsection{1 - Tecidos Medidos}

As amostras de tecido mamário estudadas foram obtidas no Departamento de Patologia do Hospital das Clínicas da Faculdade de Medicina de Ribeirão Preto. O material colhido para análise correspondia a uma fração dos tecidos retirados em procedimentos cirúrgicos de mastectomia e mastoplastia. O volume de tecido colhido era determinado de forma a se ter uma amostra tão homogênea quanto possível e em quantidade suficiente para ser irradiada. Depois de colhidas, as amostras eram armazenadas à temperatura ambiente em recipientes plásticos contendo solução de formol tamponado (10\%).

As amostras de tecidos mamários foram classificadas como tecidos normais (adiposo e glandular), fibroadenomas e carcinomas ductais invasivos de grau I, carcinomas ductais invasivos de grau II, carcinomas ductais invasivos de grau III, e carcinoma mucinoso, conforme o critério de classificação de Bloom e Richardson (BLOMM E RICHARDSON, 1957). A classificação histológica foi realizada através da análise das 
lâminas de tecido por médicos do Departamento de Patologia do Hospital das Clínicas e reclassificadas por um especialista em patologias.

\subsection{2 - Forma das amostras}

As dimensões das amostras são restritas por dois fatores: (a) ter um número razoável da contagem de fótons espalhados em um intervalo de tempo, e (b) o alvo não deve ter dimensões muito grandes de forma a minimizar efeitos de múltiplo espalhamento e de atenuação do feixe pelo recipiente. Os tecidos mamários foram retirados da solução de formol e cortados no tamanho adequado para serem acomodados em um recipiente acrílico cilíndrico (porta-amostra) construído com diâmetro interno de $18 \mathrm{~mm}$ e uma altura de 4

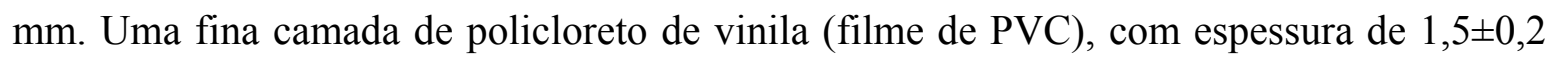
$\mu \mathrm{m}$, foi utilizada recobrindo a amostra de forma a sua superfície se tornar o mais regular possível. Para se minimizar os efeitos do formol na medida do espalhamento, o excesso da solução remanescente na amostra foi retirado utilizando-se papel absorvedor.

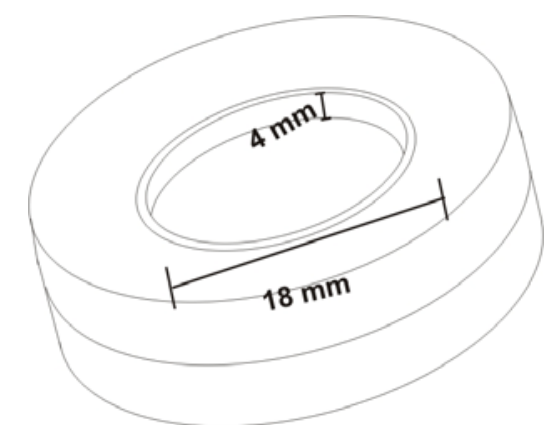

Figura 3.1: Porta-amostra utilizado nas medidas. 


\section{2 - Arranjo experimental}

O arranjo experimental foi montado no Laboratório de Difratometria do Departamento de Química da Faculdade de Filosofia, Ciências e Letras de Ribeirão Preto da Universidade de São Paulo e é mostrado na figura 3.2.

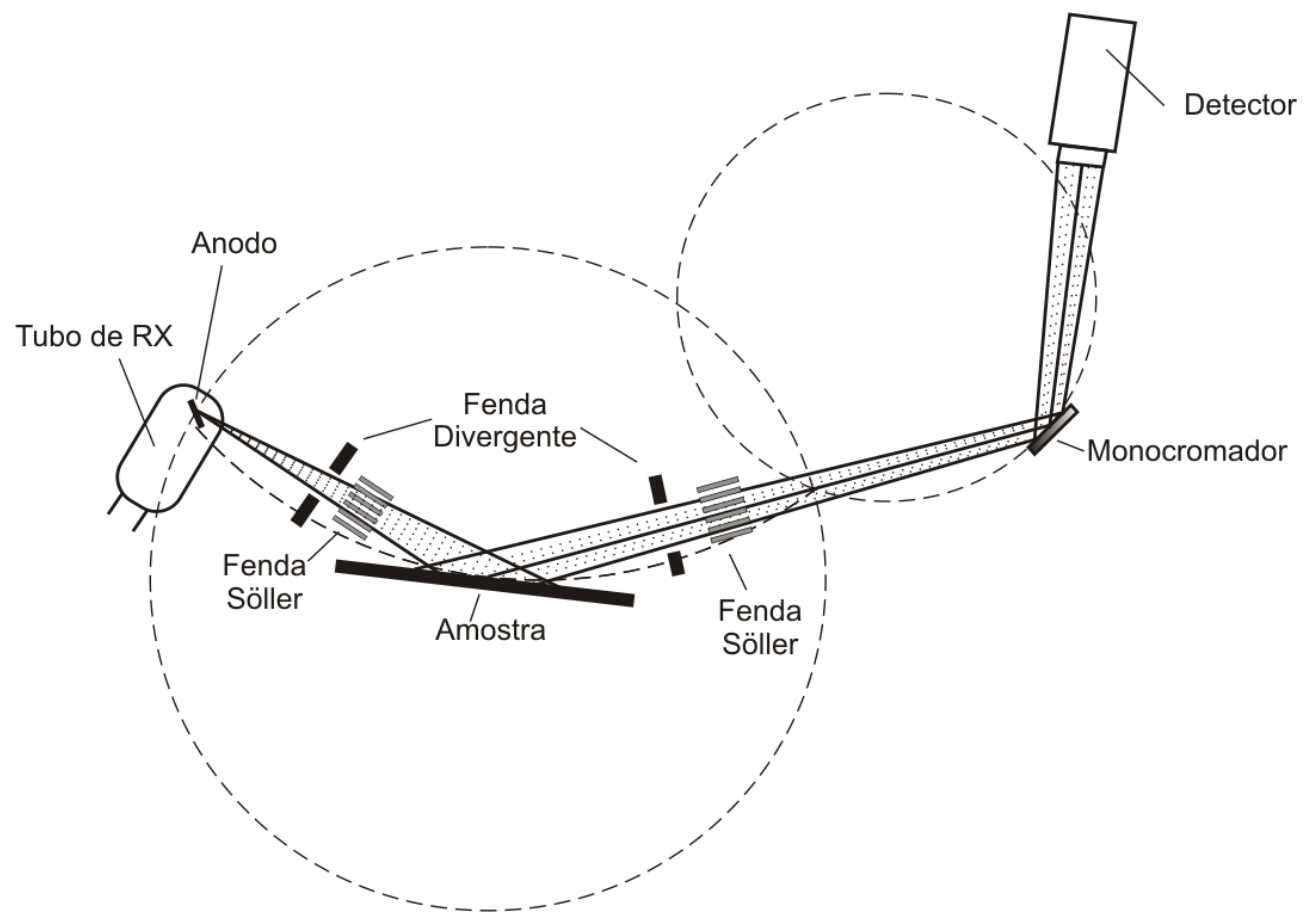

Figura 3.2: Arranjo experimental para as medidas de difração de raios-X.

Utilizou-se um difractômetro comercial Siemens D-5005, operando no modo reflexão. O tubo de raios-X possuía um anodo de $\mathrm{Cu}\left(\mathrm{Z}=29, \mathrm{~K}_{\alpha}=8.04 \mathrm{keV}\right.$ e $\mathrm{K}_{\beta}=8.91$ $\mathrm{keV}$ ). O feixe emergente do anodo era colimado por uma fenda divergente vertical com abertura variável localizada à uma distância de $85 \pm 1 \mathrm{~mm}$ do anodo, e em seguida passava por uma fenda Söller que tornava o feixe incidente paralelo na horizontal, localizada à $35 \pm 1 \mathrm{~mm}$ da fenda divergente. A fenda com abertura variável era utilizada para se obter na 
amostra uma área irradiada constante de $6 \times 12 \mathrm{~mm}^{2}$ à medida em que variava o ângulo de incidência e detecção, conforme mostra a figura 3.3. O porta-amostra foi posicionado no centro do goniômetro localizado sobre o eixo central do difractômetro e à $210 \pm 1 \mathrm{~mm}$ do anodo, e girava de forma que o ângulo incidente e o ângulo espalhado fossem iguais em relação à superfície da amostra.

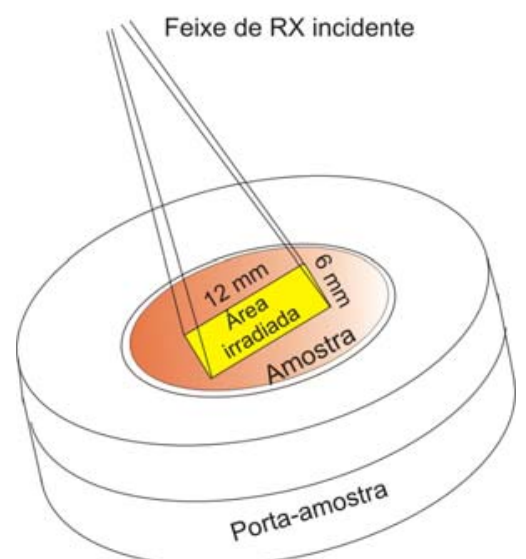

Figura 3.3: área do porta-amostra irradiada.

O feixe de Raios-X espalhado na amostra atravessava uma fenda divergente com abertura variável à $135 \pm 1 \mathrm{~mm}$ do centro do goniômetro e uma fenda Söller localizada à $25 \pm 1 \mathrm{~mm}$ da fenda divergente. O feixe espalhado atingia então o monocromador de Grafite $(2 d=0.2708 \mathrm{~nm})$ à $100 \pm 1 \mathrm{~mm}$ da fenda Söller, selecionando os fótons espalhados com eficiência de quase $100 \%$. A radiação espalhada atingia finalmente o detector de cintilação, com eficiência de $95 \%$ na energia selecionada. A eficiência do detector para a energia de $8.04 \mathrm{keV}$ é de 95\%. O detector estava associado à uma eletrônica padrão (fotomultiplicadora, amplificador) e conectado ao microcomputador por uma placa de interface. O software de aquisição dos dados foi desenvolvido pelo próprio fabricante do difractômetro. 
Os fótons espalhados eram detectados variando o ângulo de espalhamento no intervalo $5^{\circ}-150^{\circ}$, em passos de $1 / 3$ de grau, com tempo de contagem típico de 20 s, garantindo assim uma boa contagem de fótons no detector, com uma incerteza estatística de 4\%. O tamanho do passo escolhido era suficiente para detectar a existência de picos de espalhamento, uma vez que a largura à meia altura dos picos era de no mínimo $2^{\circ}$ para tecidos mamários normais e $9^{\circ}$ para tecidos neoplásicos, na energia utilizada. Medidas adicionais foram realizadas para a subtração do fundo: $(i)$ com o porta-amostras vazio, mantida a camada de PVC, (ii) com o porta-amostras vazio e sem o filme de PVC e (iii) sem nenhum tipo de alvo além do ar.

Os dados obtidos foram posteriormente usados de forma a subtrair as contribuições espúrias, e em seguida corrigidos devido à variação da atenuação na amostra e da intensidade do feixe em função do ângulo.

\section{3 - Intensidade espalhada pela amostra: correção por contribuições espúrias}

Considera-se como contribuição espúria ao perfil de espalhamento qualquer contagem de fótons que chegue ao detector, mas que não seja oriunda da amostra de tecido analisada. Devido ao arranjo experimental utilizado podemos ter várias dessas fontes de espalhamento, tais como o espalhamento do feixe de raios X no ar, sobre o filme de PVC que cobre a amostra, e ainda devido ao fato de o feixe incidente na amostra não ser totalmente atenuado pela mesma e terminar atingindo o porta-amostra de acrílico, o que faz com que este também se torne uma fonte de espalhamento de raios X. Poderia ser citada também a contribuição proveniente de raios cósmicos e também da radiação natural do 
ambiente. Apesar destes dois últimos fatores não terem sido medidos isoladamente, foram levados em conta nas correções quando se media a contribuição de fótons espalhados pelo ar.

A figura 3.4 mostra um esquema simplificado da disposição de todos os elementos que contribuem para o sinal do espalhamento detectado.
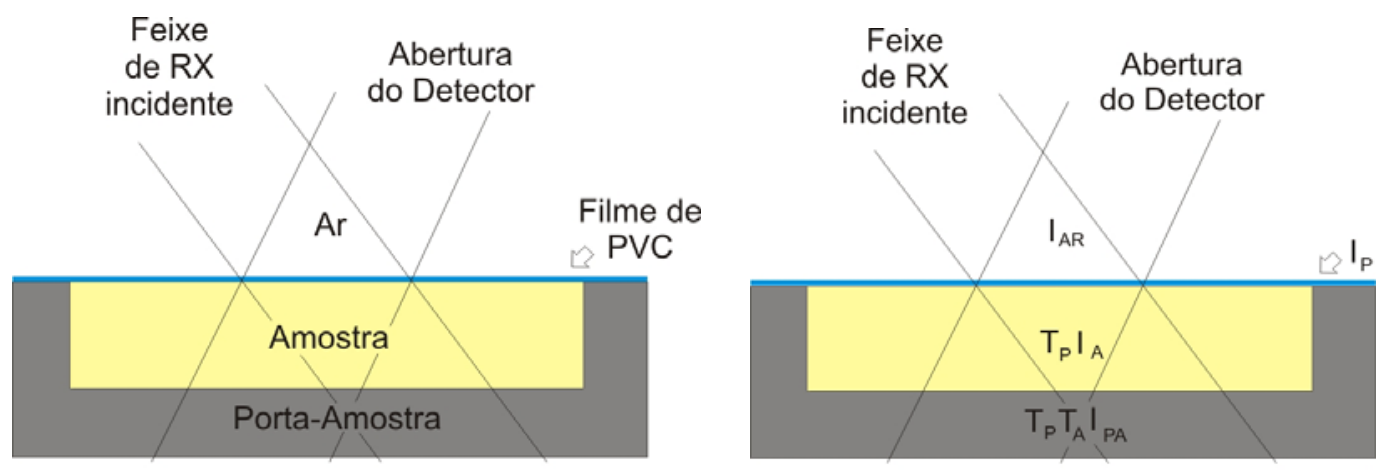

Figura 3.4: (a) Representação esquemática do arranjo experimental utilizado para medida das amostras de tecido. (b) Contribuição de cada parte do arranjo ao espalhamento.

À partir da figura 3.4-b podemos escrever então a intensidade de fótons espalhados medida experimentalmente no difractômetro como sendo a soma das seguintes contribuições:

$$
I_{M(\theta)}=T_{P} I_{A(\theta)}+I_{P(\theta)}+T_{P} T_{A} I_{P A(\theta)}+I_{A R}
$$

onde $I_{M(\theta)}$ é a intensidade espalhada medida experimentalmente, $I_{A(\theta)}$ é o espalhamento proveniente da amostra, $I_{P(\theta)}$ o espalhamento proveniente do filme de PVC que cobre a amostra, $I_{P A(\theta)}$ o espalhamento do porta-amostra e $I_{A R}$ o espalhamento do ar. $T_{P}$ e $T_{A}$ são respectivamente os fatores de transmissão do filme de PVC e da amostra. Através da figura 3.4-b pode-se ver a necessidade de se considerar os fatores de atenuação do filme de PVC e 
da amostra, $T_{P}$ e $T_{A}$ respectivamente, uma vez que o feixe incidente na amostra é antes atenuado pelo filme de PVC, enquanto que o feixe que atinge o porta-amostra atravessa antes o filme de PVC e a amostra.

Para se obter a intensidade do espalhamento devido exclusivamente à amostra devese reescrever a equação acima de forma a explicitar quais são os fatores que devem ser eliminados dos dados experimentais:

$$
I_{A(\theta)}=T_{P}^{-1}\left(I_{M(\theta)}-I_{P(\theta)}-T_{P} T_{A} I_{P A(\theta)}-I_{A R}\right)
$$

Deve-se observar que apesar de o feixe de raios-X incidente sempre atingir o portaamostras, o espalhamento do porta-amostras começa a ser observado pelo detector somente quando o detector atinge um ângulo de inclinação aproximadamente igual a $106^{\circ}$. A figura 3.5 representa as duas situações possíveis, para ângulos menores e maiores que $106^{\circ}$, respectivamente. Na figura 3.5-a o espalhamento do porta-amostras não é detectado, mas em 3.5-b sim.
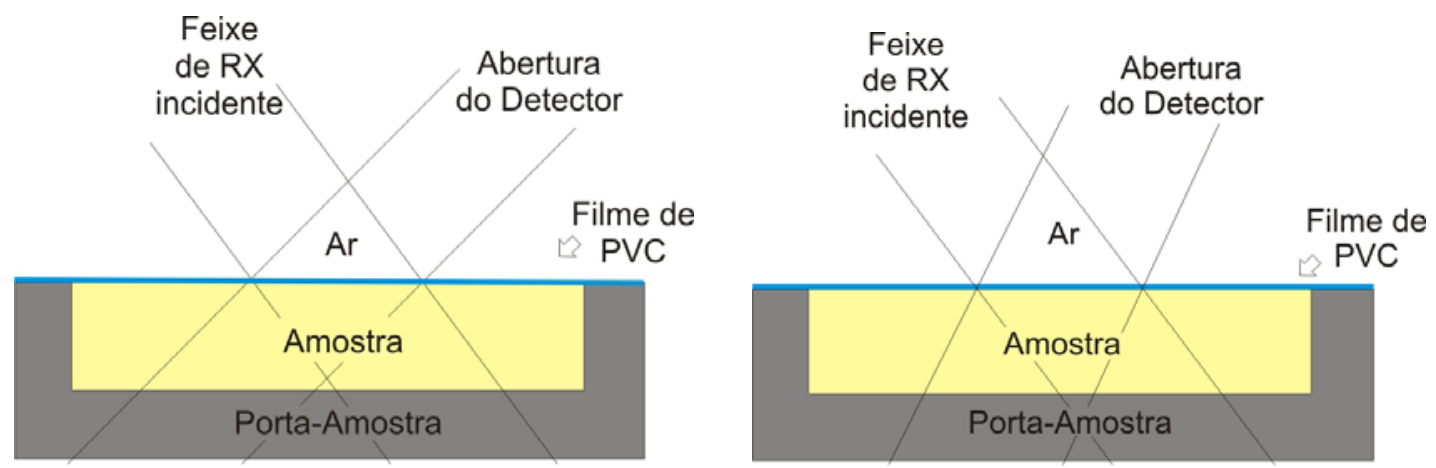

Figura 3.5: Volume irradiado que é visto pelo detector: (a) para ângulos de detecção menores que $65^{\circ}$ e (b) para ângulos maiores que $65^{\circ}$. 
Os fatores de transmissão $T_{P}$ e $T_{A}$ são obtidos através da expressão $T=e^{-2 \mu l}$, onde $\mu$ é o coeficiente de atenuação linear do material, $l$ é o caminho percorrido pelo feixe de raios $\mathrm{X}$ e o fator 2 que aparece multiplicando se deve ao fato de o feixe espalhado percorrer o mesmo caminho que o feixe incidente até chegar ao detector. Para o filme de PVC optouse por utilizar um valor constante de atenuação do filme à espessura ser extremamente

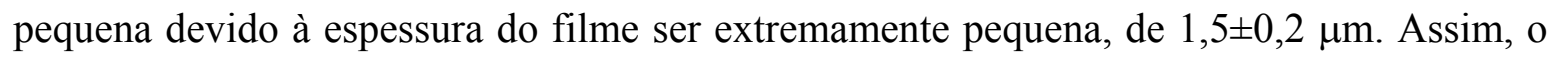
valor de $T_{P}$ encontrado para o filme de PVC é 0,974.

Para a obtenção do perfil de espalhamento do ar, filme de PVC e porta-amostras adotou-se os seguintes procedimentos:

- Perfil de espalhamento do ar $\left(I_{A R(\theta)}\right)$ : realizou-se uma medida sem que nenhum objeto estivesse sendo irradiado (figura 3.6-a), de forma que todo o espalhamento detectado fosse devido ao volume de ar na região vista pelo detector. À essa medida aplicou-se um fator de correção que leva em conta a fração de volume de ar acima do filme de PVC, determinado pelas condições geométricas e considerando os feixes paralelos. Métodos numéricos foram usados para calcular o fator de correção.

- Perfil de espalhamento do porta-amostra $\left(I_{P A(\theta)}\right)$ : Mediu-se o espalhamento do porta-amostra sozinho (figura 3.6-b), ou seja, o conjunto "porta-amostra + ar" $\left(I_{P A(\theta)}+I_{A R}\right)$, em seguida foi subtraído o sinal do espalhamento devido ao ar $I_{A R(\theta)}$.

- Perfil de espalhamento do filme de $\operatorname{PVC}\left(I_{P(\theta)}\right)$ : O porta-amostra vazio foi coberto com o filme (figura 3.6-c) e mediu-se o espalhamento do conjunto "porta-amostra + filme de PVC + ar" $\left(I_{P(\theta)}+I_{P A(\theta)}+I_{A R}\right)$. Obteve-se o perfil do filme de PVC 
subtraindo o sinal encontrado para o porta-amostra $I_{P A(\theta)}$ e também a contribuição do $\operatorname{ar} I_{A R}$.

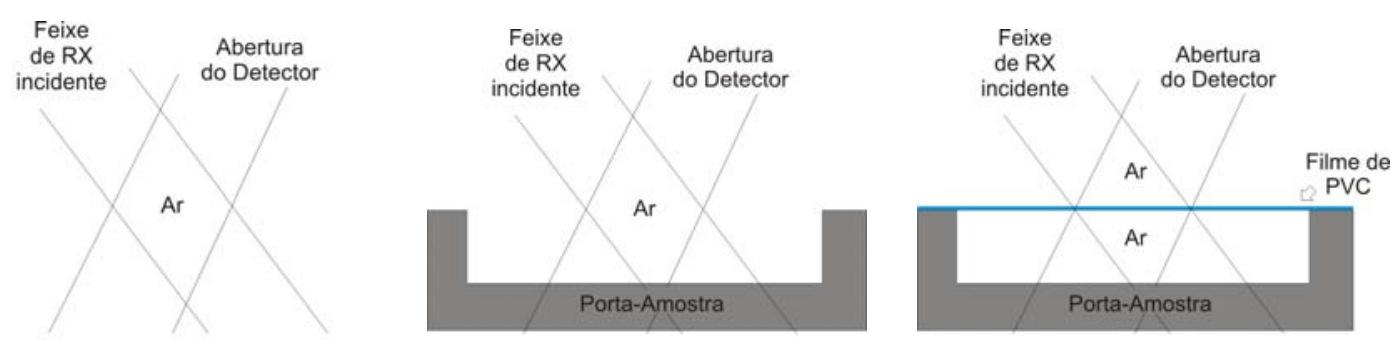

Figura 3.6: Arranjo experimental utilizado para medida do espalhamento (a) do ar, (b) do porta-amostra e (c) do filme de PVC.

Uma vez retiradas as contribuições espúrias deve-se agora obter uma relação entre o perfil de espalhamento desejado e a intensidade dos fótons espalhados pela amostra.

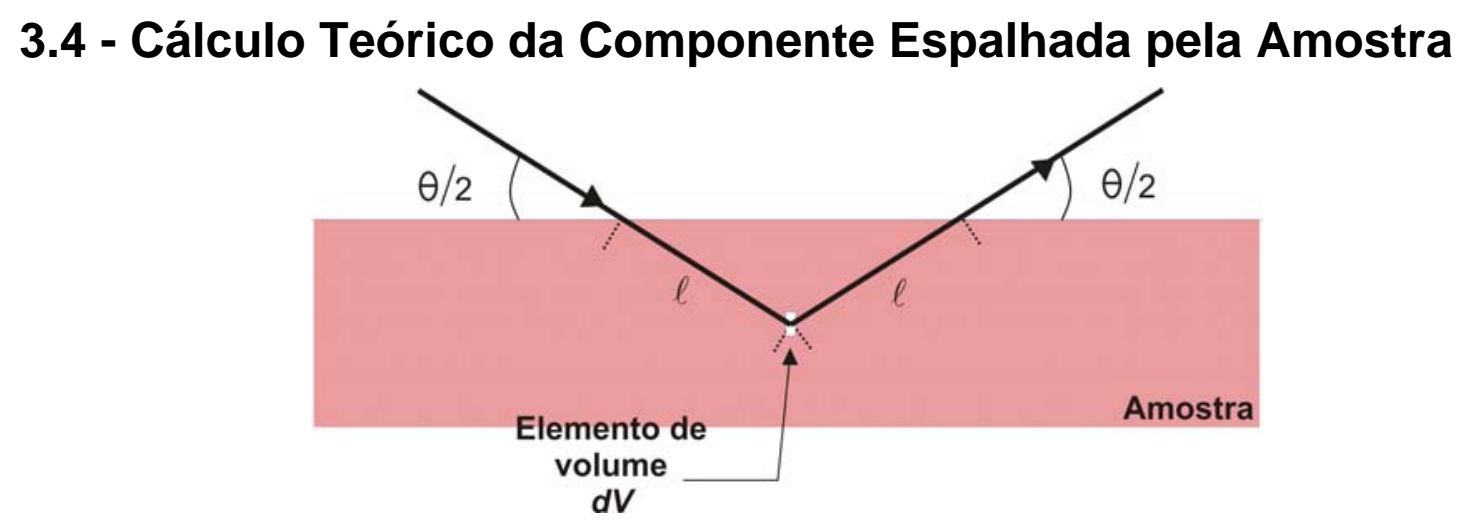

Figura 3.7: Geometria de espalhamento por reflexão utilizada.

Para calcular a componente de espalhamento proveniente de um elemento de volume $d V$ da amostra consideremos a figura 3.7. A intensidade do espalhamento $I_{A}(\theta)$ será igual ao número total de fótons espalhados em um dado ângulo, sendo dado por: 


$$
I_{A}(\theta)=\int_{V} I_{0}(\theta) e^{-\mu \ell} \frac{d \sigma}{d \Omega}(\theta) n_{v} d V e^{-\mu \ell} \Delta \Omega(\theta) \eta_{m o n} \eta_{\mathrm{det}}
$$

onde:

$I_{0}(\theta) \quad$ número de fótons incidentes por unidade de ângulo sólido,

$\mu \quad$ coeficiente de atenuação linear da amostra,

$e^{-\mu \ell} \quad$ atenuação durante $\mathrm{o}$ caminho $\ell$ percorrido da superfície ao ponto de

espalhamento da amostra,

$\frac{d \sigma}{d \Omega}(\theta) \quad$ seção de choque diferencial de espalhamento,

$d V \quad$ elemento de volume,

$n_{v} \quad$ número de partículas espalhantes por unidade de volume presentes em $d V$,

$e^{-\mu \ell} \quad$ atenuação durante o caminho $\ell$ percorrido pelo fóton desde o ponto de espalhamento até a superfície da amostra,

$\Delta \Omega(\theta) \quad$ ângulo sólido compreendido entre o ponto de espalhamento à abertura do colimador do feixe espalhado,

$\eta_{m o n} \quad$ eficiência do monocromador,

$\eta_{\text {det }} \quad$ eficiência do detector.

Como a integral da equação 3.3 é calculada sobre o volume espalhador irradiado $V$ que é visto pelo detector, os termos $I_{0}(\theta), \frac{d \sigma}{d \Omega}(\theta), \Delta \Omega(\theta)$ e $\eta_{m o n}$ dependem somente do 
ângulo, $n_{v}$ depende da amostra e $\eta_{\text {det }}$ da energia, a equação (3.3) acima pode ser reescrita como:

$$
I_{A}(\theta)=I_{0}(\theta) \frac{d \sigma}{d \Omega}(\theta) n_{v} \Delta \Omega(\theta) \eta_{m o n} \eta_{\operatorname{det}} \int_{V} e^{-2 \mu \ell} d V
$$

A integral (3.4) representa a atenuação na amostra dos feixes incidente e espalhado de todos os diferenciais de volume. Desta forma $A=\frac{1}{V} \int_{V} e^{-2 \mu \ell} d V$ representa o fator de atenuação para cada ângulo. 


\subsection{1 - Cálculo da atenuação}

O fator de atenuação pode ser calculado seguindo o método proposto por Milberg (MILBERG, 1958), considerando algumas variações decorrentes da condição de área irradiada constante. $\mathrm{O}$ volume total irradiado $V$, visto pelo detector, pode ter duas formas de acordo com o ângulo de incidência dos feixes. Em ângulos menores que um determinado ângulo crítico $\left(\theta \leq \theta_{c}=106,26^{\circ}\right)$ o volume $V$ vai ser o triângulo $C D P$ representado na figura 3.8-a, enquanto que para ângulos maiores $\left(\theta>\theta_{c}\right)$ o volume $V$ vai ser representado pelo trapézio $C D E F$.
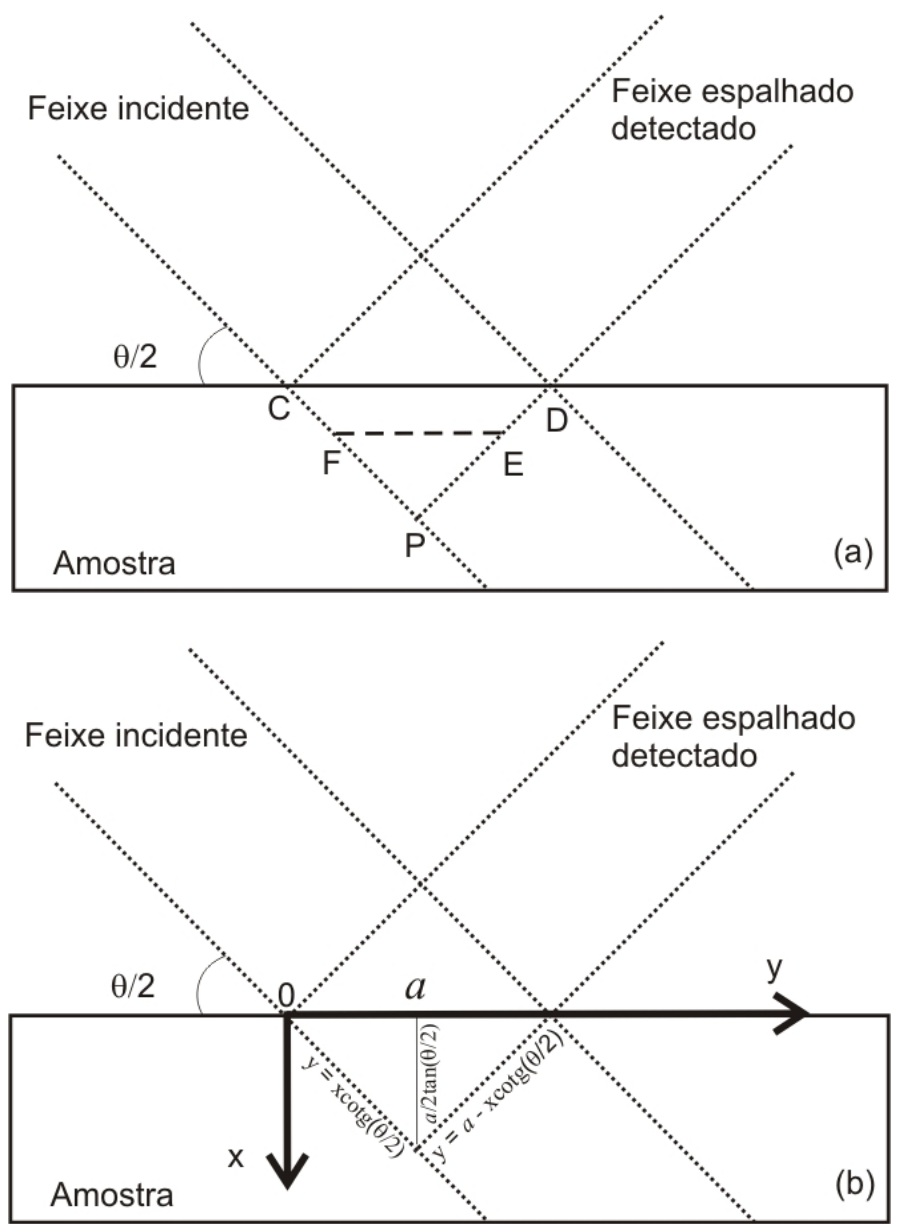

Figura 3.8: (a) Volume espalhado detectado, (b) limites de integração. 
A largura do feixe varia atingindo uma área constante $S$ da amostra (onde $S=a w$, com $w$ sendo a largura do feixe). A integral da equação (3.4) pode ser escrita considerando-se os limites de integração representados na figura 3.8-b. Para $\theta \leq \theta_{c}$, teremos:

$$
\int_{V} e^{-2 \mu l} d V=\frac{w}{2 \mu}\left[\left(\frac{1}{\mu} \operatorname{sen}(\theta / 2) \cos (\theta / 2)\right) e^{-\mu a / \cos (\theta / 2))}+\operatorname{sen}(\theta / 2)\left(a-\frac{1}{\mu} \cos (\theta / 2)\right)\right]
$$

Para $\theta>\theta_{c}$, teremos:

$$
\begin{gathered}
\int_{V} e^{-2 \mu l} d V=\frac{w}{2 \mu}\left\{\left[2 t \cos (\theta / 2)-a \operatorname{sen}(\theta / 2)+\frac{1}{\mu} \cos (\theta / 2) \operatorname{sen}(\theta / 2)\right] e^{-2 \mu t / \operatorname{sen}(\theta / 2)}+\right. \\
\quad+\operatorname{sen}(\theta / 2)\left(a-\frac{1}{\mu} \cos (\theta / 2)\right)
\end{gathered}
$$

A atenuação também foi encontrada com o auxílio de cálculos numéricos, discretizando-se o volume em pequenos diferenciais de volume e calculando-se a média do coeficiente de transmissão para cada volume.

Substituindo as soluções (3.5) e (3.6) na equação (3.4) obtem-se a solução para $I_{A}(\theta)$. 


\subsection{2 - Cálculo da correção da intensidade por área de irradiação constante (correção da intensidade)}

Como já mencionado anteriormente, durante o processo de medida manteve-se a área de irradiação constante sobre a superfície da amostra. Para isso, as aberturas das fendas divergentes deviam variar com o ângulo de medida. O difractômetro utilizado apresenta um recurso próprio para esse tipo de configuração. Uma maior abertura da fenda ocasiona uma maior intensidade do feixe que atinge a mesma área da amostra, ou seja, aumenta o número de fótons que chegam à amostra. Dessa forma, há a necessidade de que as medidas realizadas pela variação da intensidade do feixe, provocada pelo aumento da abertura da fenda sejam corrigidas.

O fator de variação da intensidade foi obtido experimentalmente, utilizando-se um método constituído de duas etapas, conforme descrito a seguir:

Na primeira etapa obteve-se o valor do ângulo de divergência da fenda em cada ângulo de medida. $\mathrm{O}$ ângulo de divergência era obtido através do próprio software de controle do sistema.

Na segunda etapa foi utilizado como alvo um cristal monocromador com ângulo de difração de cristal conhecido. Colocou-se o conjunto fonte-detector na condição de reflexão do monocromador, ou seja, de forma que toda radiação proveniente da fonte com energia de $8,04 \mathrm{keV}$ chegasse ao detector. Variava-se manualmente o ângulo de divergência na fenda utilizando-se o software do próprio sistema do difractômetro, e mantendo-se o conjunto fonte-detector na mesma posição. Nesta etapa realizava-se a leitura da intensidade espalhada no detector para cada ângulo de divergência da fenda. Quando o campo de radiação que atingia a amostra (monocromador) era maior que o próprio monocromador, mudava-se o ângulo do conjunto fonte-detector para uma nova condição de reflexão do monocromador. 
Como resultado da primeira etapa obteve-se a variação da divergência na fenda em função do ângulo de incidência na amostra. Na segunda etapa foi obtido, a variação da intensidade do feixe em relação à abertura de divergência da fenda. A correção de intensidade desejada foi encontrada combinando-se os resultados obtidos nos dois procedimentos descritos, isto é, obtendo-se a variação da intensidade espalhada de acordo com a variação do ângulo de incidência do feixe na amostra. $\mathrm{O}$ resultado final foi ainda normalizado pela intensidade do primeiro ângulo de medida das amostras $(\theta=$ $5^{\circ}$ ). Desta forma, o valor de normalização para o primeiro ângulo de medida foi de uma unidade.

\subsection{3 - Fator de polarização}

Quando um monocromador é utilizado, o feixe emergente será parcialmente polarizado (JAMES, 1962), então, há a necessidade de se corrigir a contagem de fótons medida por um fator $P$ dado por (AZARROF, 1968):

$$
P=\frac{1+\cos ^{2} \theta \cos ^{2} \theta_{M}}{1+\cos ^{2} \theta}
$$

\subsection{4 - Calculo do Fator de Normalização}

A normalização consiste em comparar a quantidade experimental corrigida considerando todos os fatores de correção antes mencionados com os valores teóricos para as seções de choque diferencial em momentos transferidos altos, onde é esperado que os efeitos de interferência não sejam significantes. 
O fator de normalização $K$ pode ser calculado como a média da razão entre os dados teóricos $N_{T}$ e os dados experimentais correspondentes $I_{A}$, no intervalo de 3,5$5,6 \mathrm{~nm}^{-1}$, que além de assegurar a condição antes mencionada, também representa um período completo onde dois máximos adjacentes de difração sejam quase imperceptíveis (POLETTI, 2001). O fator $K$ é então dado por

$$
K=\frac{1}{n} \sum_{i} \frac{N_{T}\left(X_{i}\right)}{I_{A}\left(X_{i}\right)} \quad 3,50 \leq X \leq 5,60 \mathrm{~nm}^{-1}
$$

onde $n$ é o número de pontos medidos no intervalo escolhido.

A seção de choque diferencial de espalhamento pode então ser obtida através da equação (3.4), utilizando as correções por contribuições espúrias, por área constante e de atenuação apresentados nos tópicos anteriores

$$
\frac{d \sigma}{d \Omega}(\theta) n_{v}=\left(I_{M(\theta)}-I_{P(\theta)}-T_{P} T_{A} I_{P A(\theta)}-I_{A R(\theta)}\right)\left(T_{P} K(\theta) A \eta_{m o n} \eta_{\mathrm{det}}\right)^{-1}
$$

Se o fator $n_{v}$ for conhecido, a equação (3.9) nos dá a seção de choque diferencial de espalhamento. Por outro lado, se o fator $n_{v}$ for desconhecido, obtem-se a quantidade $\frac{d \sigma}{d \Omega}(\theta) n_{v}$ que é proporcional à seção de choque. Este fator é chamado perfil de espalhamento.

Uma vez obtido o perfil de espalhamento, deve-se então aplicá-lo a um caso de referência a fim de testar os procedimentos de medida e correção dos dados. Um resultado satisfatório indica que os procedimentos adotados são confiáveis e assim, podem ser aplicados a todas as amostras. Assim, na próxima seção serão acrescentados 
os resultados das comparações realizadas, bem como a aplicação nas medidas de espalhamento dos tecidos mamários normais e alterados. 


\section{CAPÍTULO 4 - Resultados e Discussões}

\section{1 - Tratamento dos dados}

\subsection{1 - Correção por contribuições espúrias}

A figura 4.1 mostra os perfis de espalhamento do ar $\left(I_{A R}\right)$, filme de PVC $\left(I_{P}\right)$ e porta-amostras $\left(I_{P A}\right)$ para o caso de uma amostra de água líquida. No perfil do portaamostras levou-se em consideração o fator de transmissão do filme de $\operatorname{PVC}\left(T_{P}\right)$ e da água $\left(T_{A}\right)$, uma vez que o feixe incidente atravessava anteriormente estes dois materiais. O perfil de espalhamento da água $\left(T_{P} I_{A}\right)$, considerando o fator de transmissão do filme de PVC, também está representado na figura 4.1 para fins de comparação entre as intensidades obtidas.
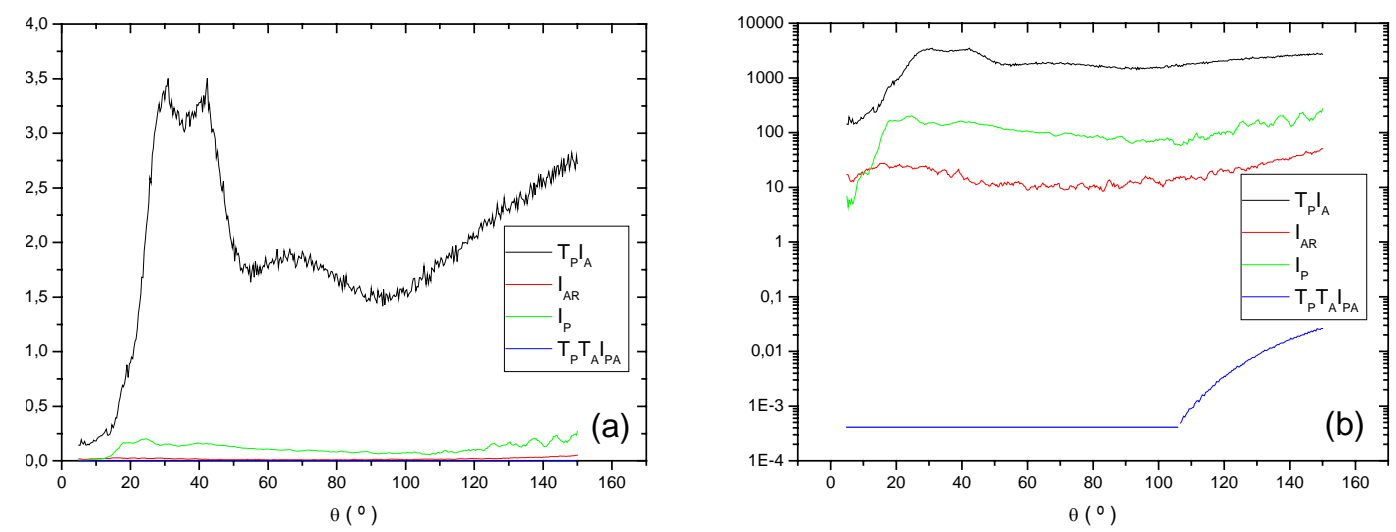

Figura 4.1: Medida experimental das contribuições espúrias, representadas de duas formas: (a) escala linear e (b) escala logarítmica.

Pode-se ver pela figura 4.1 que a correção dos dados obtidos experimentalmente são necessárias, pois as fontes espúrias contribuírem com até 10\% do espalhamento total de uma amostra. Nota-se ainda que a maior contribuição espúria provém do filme de PVC, 
e é mais significativa na região de ângulos baixos, possuindo um pico de espalhamento em torno de $20^{\circ}$. A contribuição do porta-amostra é praticamente nula, pelo fato de o feixe incidente ser atenuado pelo filme de PVC e pela amostra antes de atingi-lo. Além disso, os fótons espalhados pelo porta-amostra só começam a ser detectados em ângulos maiores que $106^{\circ}$. A contribuição do ar para o espalhamento é significativa apenas para ângulos muito pequenos.

\subsection{2 - Atenuação e fatores geométricos}

Conforme descrito na seção 3.4.1, o fator de correção devido à atenuação foi obtido tanto por método analítico, quanto por método numérico. A figura 4.2 mostra os resultados obtidos para a atenuação analítica, equações (3.5) e (3.6), e os resultados numéricos para uma amostra de água. Como pode ser visto na figura 4.2, os dois métodos levaram aos mesmos resultados.

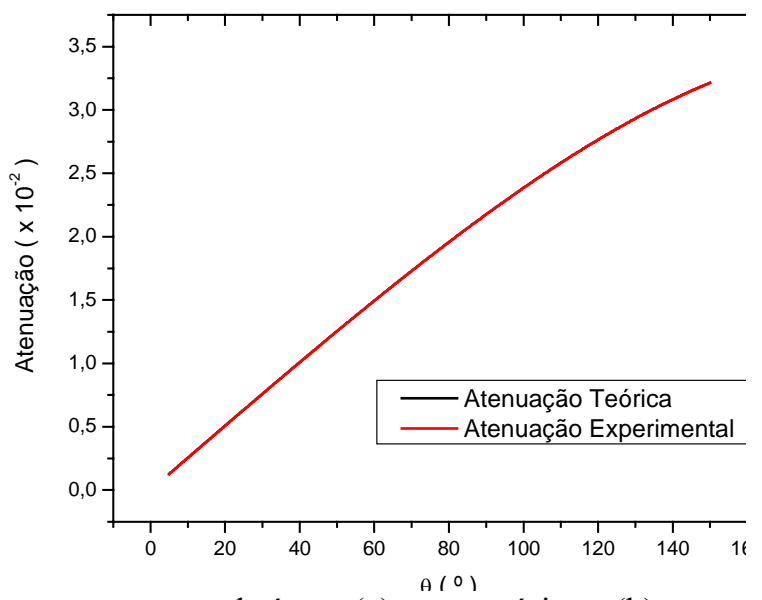

Figura 4.2: Atenuação para uma amostra de água: (a) curva teórica e (b) curva obtida por métodos numéricos. 


\subsection{3 - Correção por área de irradiação constante}

A figura 4.3 mostra a correção pela intensidade do feixe incidente obtida experimentalmente.

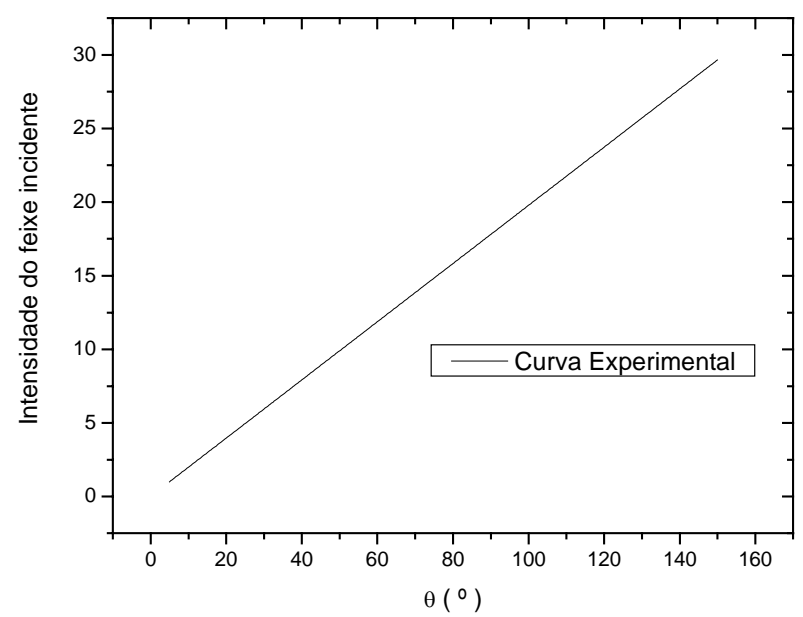

Figura 4.3: Variação da intensidade do feixe incidente experimentalmente.

\subsection{4 - Correção por polarização}

A figura 4.4 mostra a correção por polarização utilizada. A curva está dividida pelo fator de polarização de Thomson $\left(1+\cos ^{2} \theta\right) / 2$, para comparação dos perfis de espalhamento. 


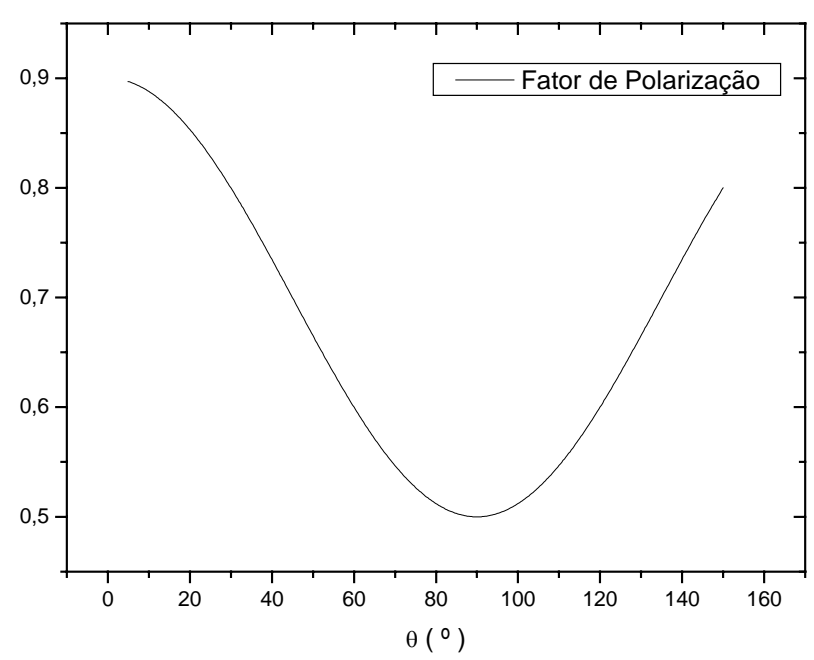

Figura 4.4: Fator de polarização.

\subsection{5 - Aplicação das correções e avaliação do procedimento experimental}

A figura 4.5-a mostra o perfil de espalhamento corrigido para uma amostra de água, comparado com a seção de choque diferencial obtida através do fator de forma tabulado por Morin (MORIN, 1982). Conforme pode ser visto através da figura 4.5-b, a diferença percentual relativa entre o resultado teórico e o experimental foi de aproximadamente $9 \%$, dentro das incertezas experimentais (produto das combinações das incertezas provenientes das contribuições espúrias (7\%), atenuação (5\%) e variação da intensidade incidente para se manter uma área de irradiação constante sobre a amostra (3\%)), mostrando que o procedimento de tratamento dos dados realizado foi satisfatório. 


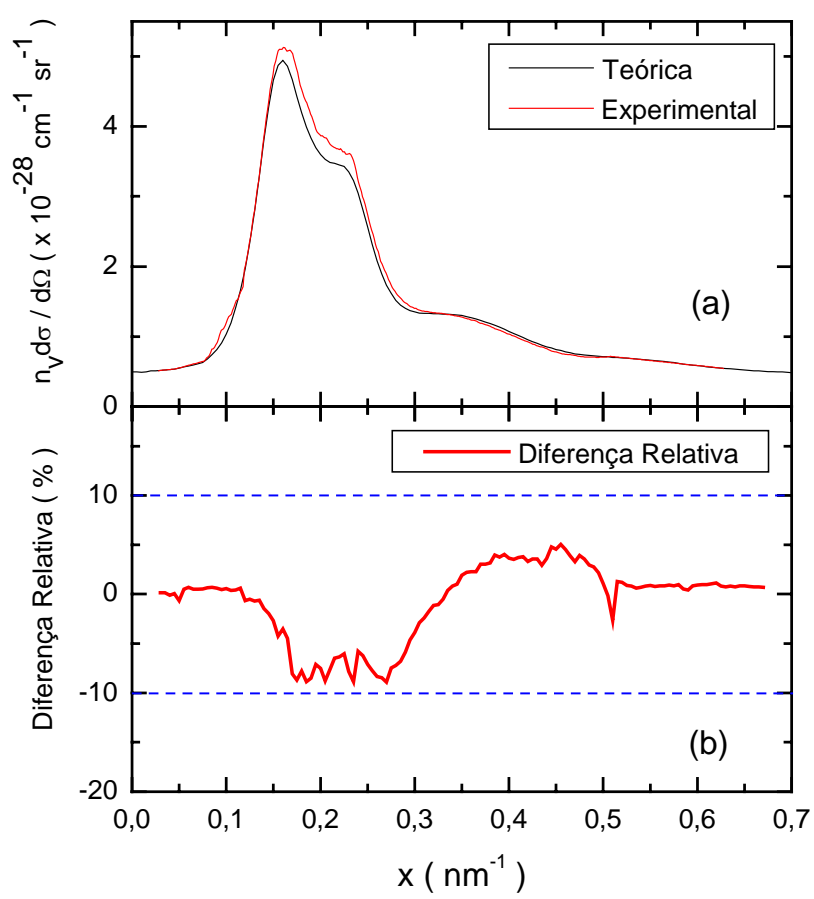

Figura 4.5: (a) perfil de espalhamento da água obtido experimentalmente comparado à seção de choque diferencial obtida através dos fatores de forma obtidos por Morin (MORIN, 1982); (b) diferença relativa entre as curvas da figura (a).

\section{2 - Apresentação dos perfis de espalhamento e sua comparação com a análise histológica das laminas e os dados encontrados na literatura}

\subsection{1 - Amostras de tecidos mamário medidas}

Foram medidos os perfis de espalhamento de 45 tecidos normais (TN), 13 fibroadenomas (FA), 8 carcinomas ductais invasivos de grau I (CDI), 12 de grau II (CDII), 4 de grau III (CDIII) e 1 carcinomas mucinoso (CM), classificados histologicamente conforme o critério de Bloom e Richardson (BLOMM E RICHARDSON, 1957). A figura 4.6 mostra uma distribuição com a classificação histológica dos tecidos medidos. 


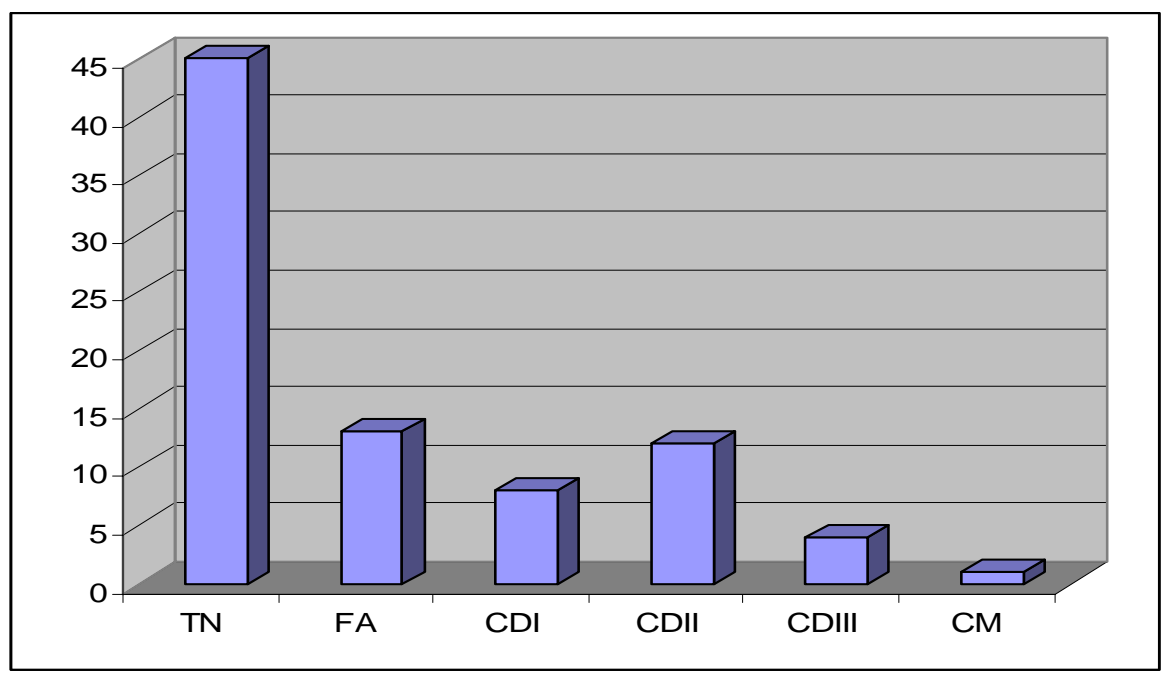

Figura 4.6: Distribuição das amostras medidas.

\subsection{2 - Perfil de espalhamento obtidos das medidas das amostras de tecido mamário}

\subsubsection{1 - Tecidos mamários normais}

Os tecidos mamários são compostos basicamente por tecido adiposo e fibroglandular. O tecido adiposo é um tipo de tecido que se caracteriza pela presença de células especializadas em armazenar lipídios, conhecidas como adipócitos. Quando a gordura corporal aumenta, os adipócitos alcançam um limite biológico superior. $\mathrm{O}$ aumento na gordura corporal resulta habitualmente no "enchimento" das células com gordura e não no aumento do número de células. A exceção ocorre quando a dimensão dos adipócitos alcança o máximo e a massa adiposa aumenta mais com a proliferação adicional de adipócitos. A estrutura destas células é predominantemente formada por triglicerídeos, nomenclatura dada à união de três ácidos graxos com uma molécula de glicerol (LEHNINGER ET AL, 1993; STRYER ,1992 e 2004; VOET,1995).

O tecido fibro-glandular é responsável pela produção e secreção do leite materno. Este tecido é constituído por lóbulos e ductos circundados pelos estromas intra e interlobular (tecido fibroso denso responsável pela sustentação da mama). Os lóbulos 
mamários são as unidades secretoras da mama. Cada lóbulo é constituído por ácinos situados no estroma intralobular. Os ácinos são formados basicamente por membranas fosfolipídicas, proteínas e pelo líquido intracelular - sendo este o seu principal componente, que é constituído de $70 \%$ de água. Os ductos mamários são responsáveis pela drenagem dos lóbulos. Têm contorno irregular ou estrelado (LEHNINGER ET AL, 1993; STRYER ,1992 e 2004; VOET,1995).

A figura 4.7 mostra a foto de uma lâmina de tecido mamário normal onde podese observar o sistema secretor, composto por lóbulos e ductos situados no estroma interlobular, e o tecido adiposo.

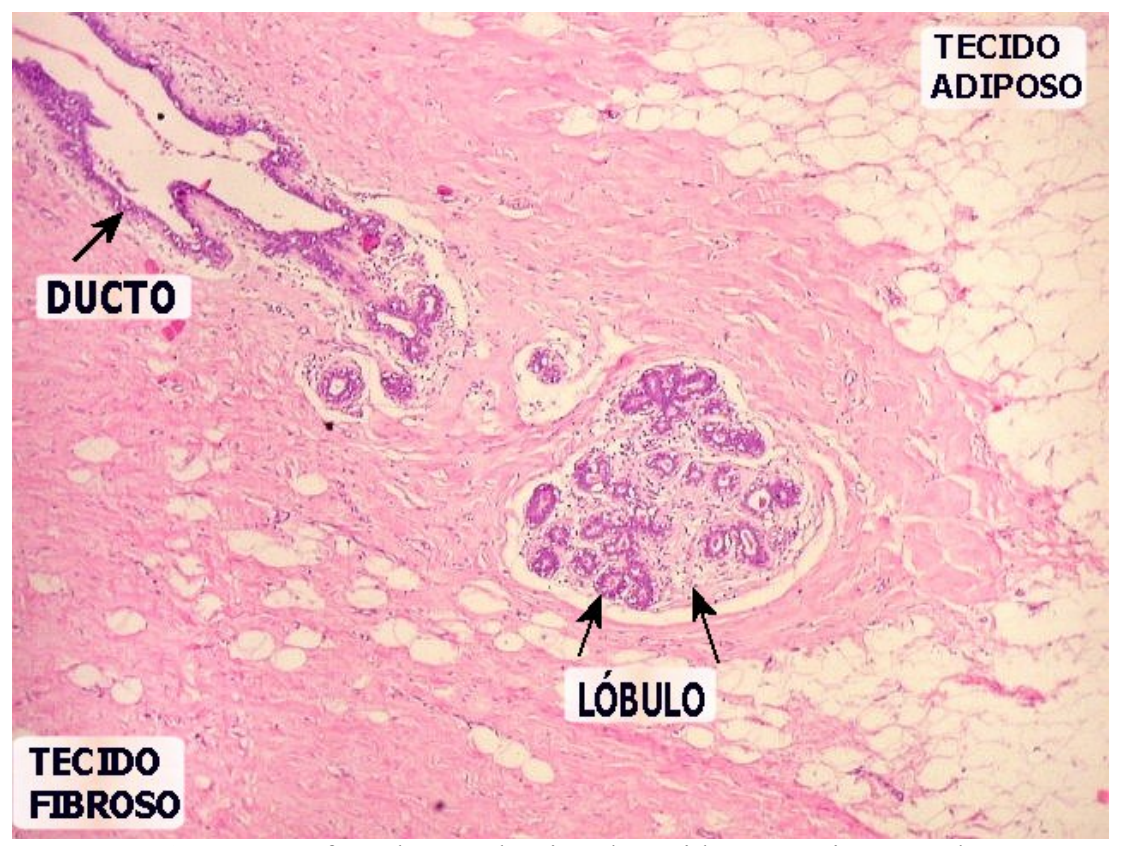

Figura 4.7: foto de uma lâmina de tecido mamário normal. 


\section{(a) Perfil de espalhamento para o tecido normal adiposo}

Na figura 4.8-a está representada a média do perfil de espalhamento obtido para todos os tecidos adiposos medidos e o caso mais típico deles. Optou-se por não mostrar o perfil de todos os tecidos medidos para não sobrecarregar a figura.

Pode-se notar através da figura 4.8-a que estes tecidos apresentam primeiro pico alto e estreito na região compreendida entre o intervalo 0,1108 - 0,1164 $\AA^{-1}$ (média $0,1136 \AA^{-1}$ ) de momento transferido. Esta estrutura está relaciona ao espalhamento construtivo de elementos que distam $4,5 \AA$ entre si. A cadeia carbônica dos ácidos graxos que formam os triglicerídeos apresenta átomos separados por uma distância de $4,5 \AA$ dos respectivos átomos da cadeia adjacente (LIDE, 1996). Isto indica que o primeiro pico de espalhamento observado para cada amostra de tecido normal corresponde à interferência construtiva formada pelos triglicerídeos que compõem o tecido adiposo. A intensidade do pico está diretamente relacionada à correlação de longo alcance e a estrutura presente na amostra, o que nos permite concluir que o tecido adiposo possui alto grau de ordenamento.

Neste trabalho, por questões de simplicidade, convencionou-se utilizar o termo pico adiposo para representar pico de espalhamento, se este ocorrer na região de 0.1136 $\AA^{-1}$. A figura 4.8-b apresenta a lamina histológica de um tecido adiposo. Pode-se notar através dela que o tecido adiposo apresenta uma estrutura organizada, sendo este o motivo pelo qual seu perfil de espalhamento apresenta um pico estreito e intenso. 

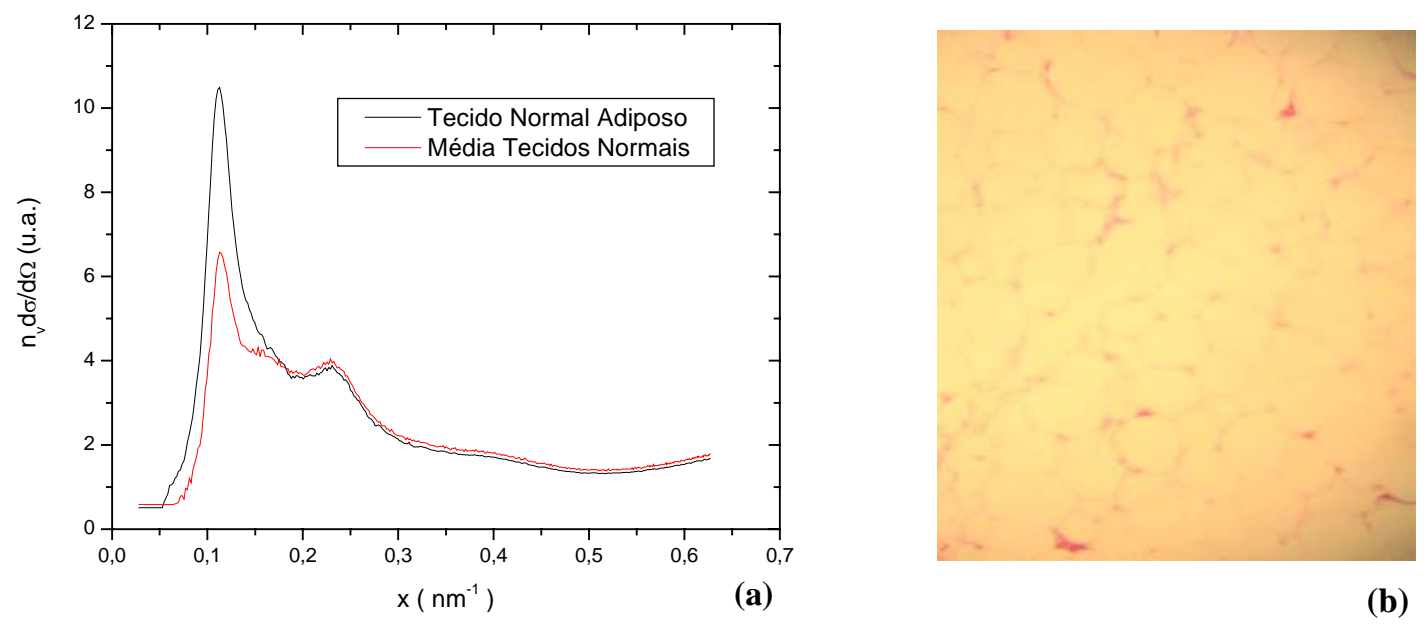

(a)

(b)

Figura 4.8: (a) perfil de espalhamento de um caso típico de tecido normal adiposo e a média dos tecidos normais medidos e (b) lâmina histológica representativa de um tecido adiposo. Cada demarcação fechada corresponde a um adipócito que contém inúmeros triglicerídeos.

\section{(b) Tecido Normal Glandular}

Alguns tecidos normais apresentam perfil de espalhamento diferente daquele mostrado na figura 4.8-a. A figura 4.9-a mostra o perfil de espalhamento médio das amostras onde isto acontece.

Pode-se notar que seus os picos de espalhamento encontram-se entre 0,1551 $0,1770 \AA^{-1}$ (media $0,1645 \AA^{-1}$ ). Esta faixa de momento está relacionada a uma distância de aproximadamente $3,0 \AA$ entre os centros espalhadores. A água líquida, principal componente dos ácinos, se organiza de tal forma que a distância entre os centros espalhadores de duas moléculas adjacentes (oxigênio-oxigênio) é de 3,0Å (VOET, 1995). Dessa forma, pode-se concluir que perfis de espalhamento que apresentam picos na região de $0,1645 \AA^{-1}$ são representativos de tecidos mamários com componente fibroglandular. As moléculas de água líquida (que compõem o tecido fibro-glandular) possuem ordenação de curto alcance, isto justifica o fato de o padrão de interferência formado ser mais largo e menos intenso que o do tecido adiposo. Analogamente ao termo pico adiposo, será também utilizado neste trabalho, o termo pico fibro-glandular 
para representar o pico que ocorre na região de $0.1645 \AA^{-1}$. A figura 4.9-b apresenta a lâmina histológica de um tecido fibro-glandular.
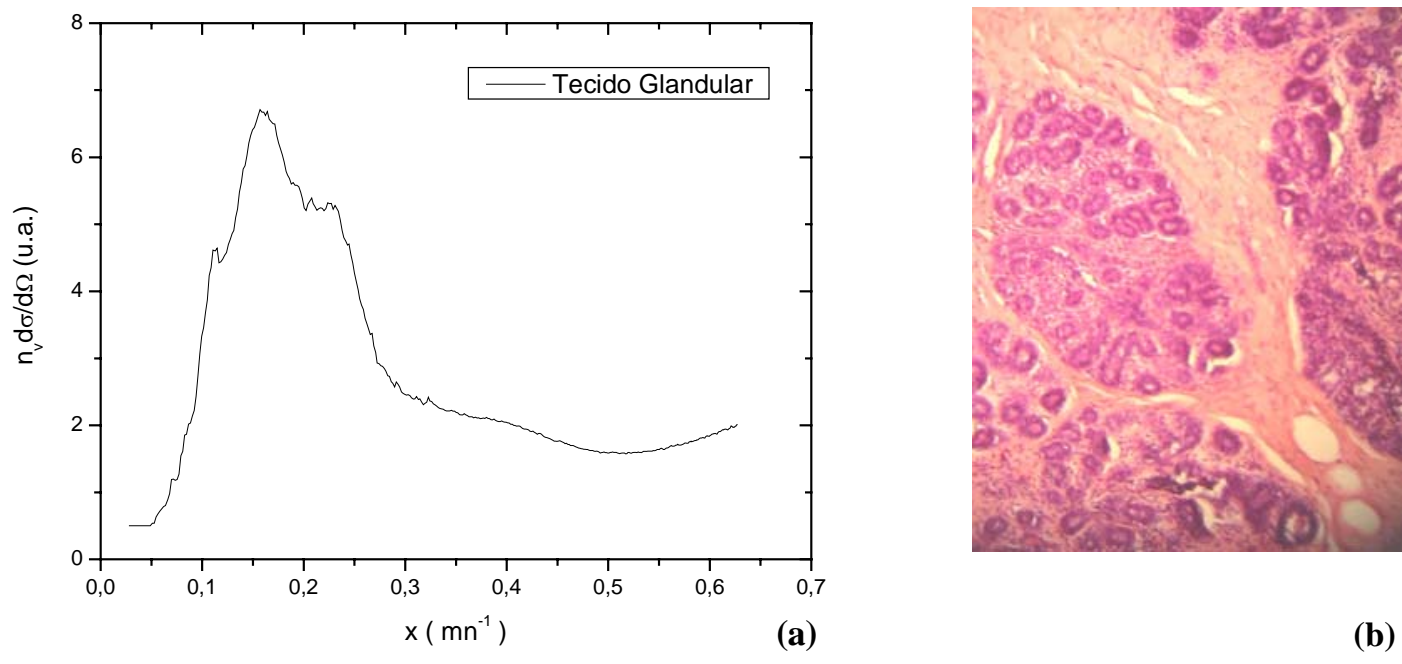

Figura 4.9: (a) perfil de espalhamento médio de um tecido normal glandular e (b) lâmina histológica representativa de um tecido fibro-glandular. $\mathrm{O}$ tecido vermelho claro representa a parte fibrosa e o tecido escuro a parte formada por ácinos.

\section{(c) Tecido Normal Misto}

Um tecido normal mamário apresenta, geralmente na sua composição, uma mistura dos tecidos adiposo e fibro-glandular. Assim, alguns tecidos normais apresentam picos tanto na região de $0,1136 \AA^{-1}$ quanto na de $0,1645 \AA^{-1}$. A figura 4.10 -a mostra o perfil de espalhamento das amostras onde esse caso acontece. A intensidade desses dois picos está relacionada com a composição do tecido, ou seja, às porcentagens de tecido adiposo e fibro-glandular. Nota-se que se o tecido apresenta uma alta porcentagem de tecido adiposo o perfil de espalhamento apresenta uma intensidade maior no pico adiposo e menor no pico fibro-glandular e vice-versa. A figura 4.10-b apresenta a lâmina histológica deste tecido misto. 

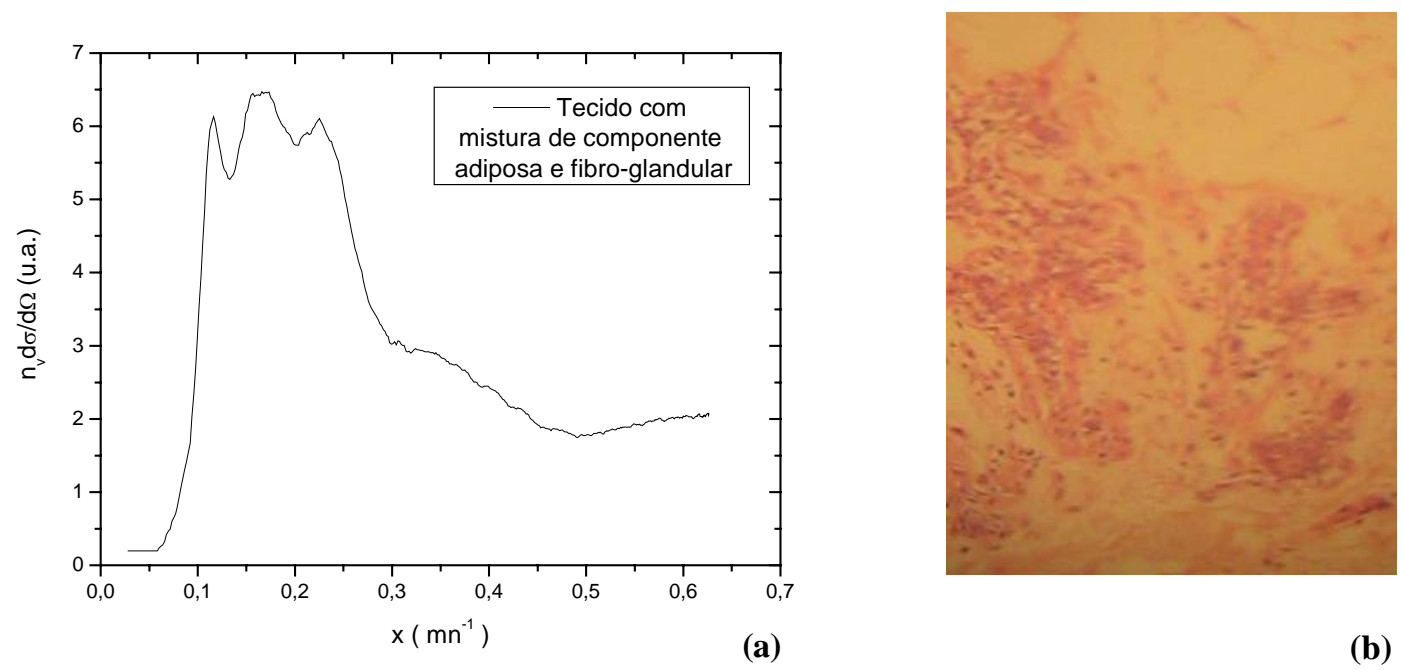

(a)

(b)

Figura 4.10: (a) perfil de espalhamento com pico adiposo e fibro-glandular, e (b) lâmina histológica representativa da mistura do tecido (aproximadamente $80 \%$ fibro-glandular e $20 \%$ adiposo).

\subsubsection{2 - Tecidos mamários alterados}

\section{(a) Alterações benignas (Fibroadenoma)}

A figura 4.11-a apresenta a curva obtida para o perfil de espalhamento médio das amostras de fibroadenoma. Esta figura também apresenta as curvas obtidas para uma amostra representativa de um caso típico e um particular desta alteração.

Nota-se que o perfil da amostra 02 apresenta pico adiposo, o que não ocorre para nenhuma das outras. A figura 4.11-b mostra a lâmina histológica obtida para este tecido. Através da foto pode-se perceber que o tecido medido apresenta tanto componente adiposo quanto fibro-glandular, o que corrobora com o fato do perfil de espalhamento obtido para esta amostra apresentar pico adiposo.

A figura 4.11-c mostra a foto histológica obtida para o caso da amostra 01, típica de fibroadenoma. Não se esperava encontrar o pico adiposo no perfil de espalhamento desta amostra, já que o caso típico não apresenta componente adiposa. Por outro lado, a componente fibro-glandular do fibroadenoma apresenta uma pequena modificação na 
sua estrutura interna em relação ao tecido não alterado. Assim, já era de se esperar que o perfil de espalhamento obtido para este tecido fosse próximo ao perfil fibro-glandular.
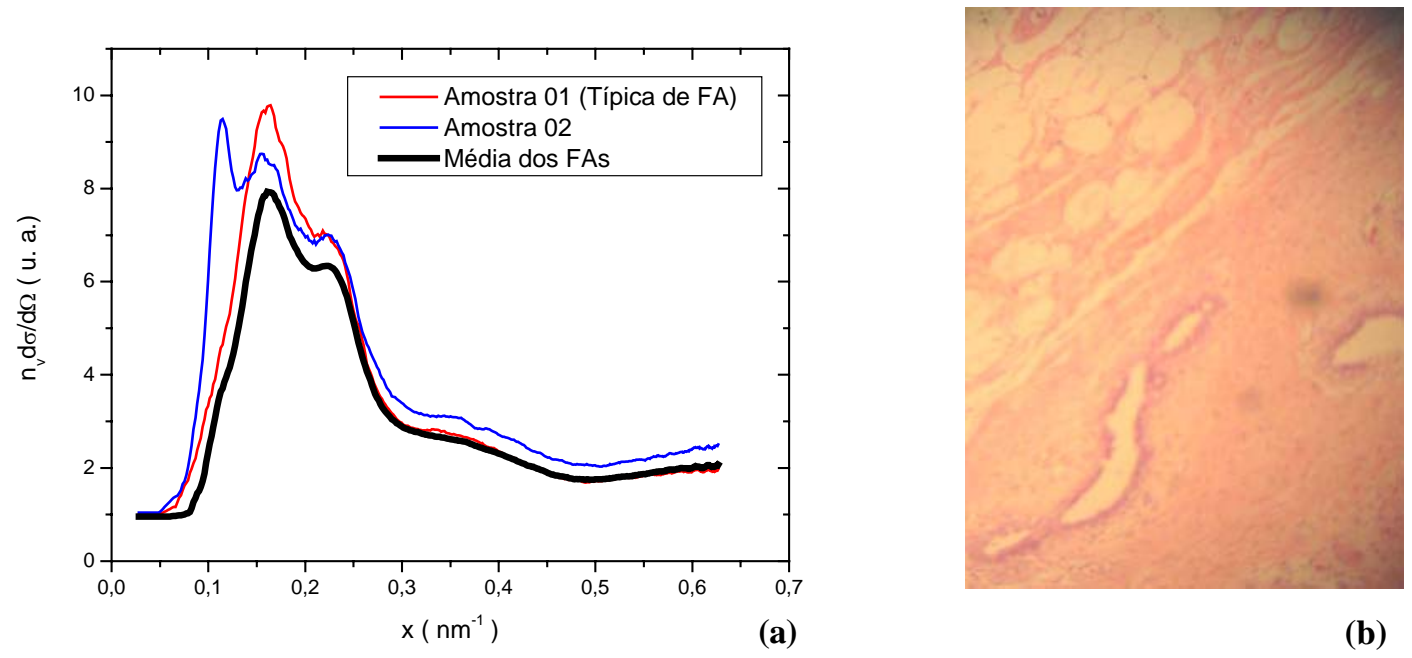

(a)

(b)

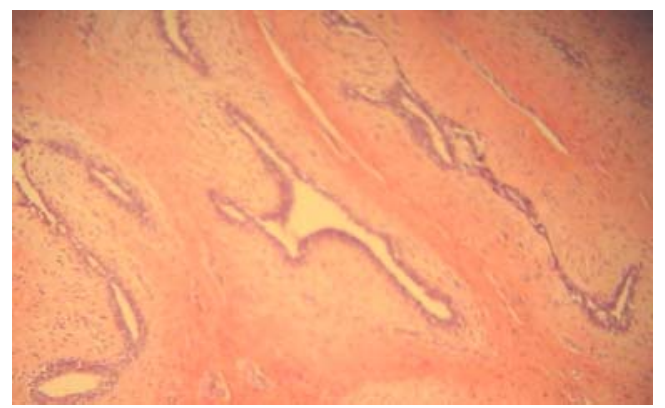

(c)

Figura 4.11: (a) perfil de espalhamento médio, típico e um caso particular de fibroadenoma; (b) lâmina histológica de um fibroadenoma com presença de tecido adiposo (amostra 02); (c) lâmina histológica de um caso típico de fibroadenoma (amostra 01).

\section{(b) Alterações malignas}

Os tumores malignos são subdivididos em classes como carcinoma ductal invasivo (de grau I, II e III, CDI, CDII e CDIII, respectivamente), carcinoma lobular (CL) e carcinoma mucinoso (CM), entre outros (ROSEN, 1996). Os carcinomas ductais são graduados usando-se critérios como formação tubular, grau nuclear e índice de mitose (BLOOM E RICHARSON, 1957).

Os componentes de uma mama normal (lóbulos, ductos, estroma e tecido adiposo) encontram-se concentrados em regiões delimitadas ou bem distinguíveis uma 
da outra, enquanto que numa mama alterada esses componentes começam a se misturar entre si, não se distinguindo zonas bem delimitadas de cada um deles. A figura 4.12 ilustra este fato.

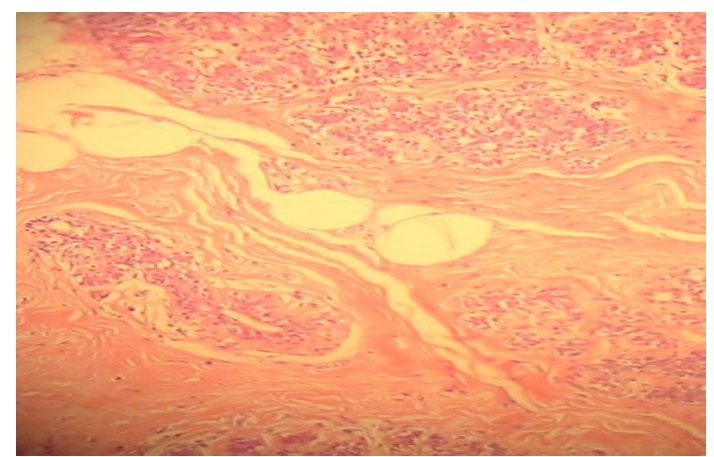

(a)

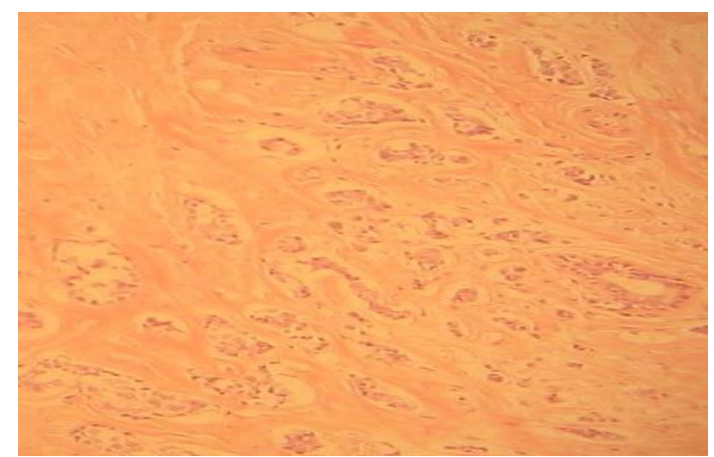

(b)

Figura 4.12: (a) lóbulos e estroma em regiões bem definidas (b) os ácinos e o estroma se misturam.

Os tópicos seguintes mostram os perfis de espalhamento obtidos para os quatro tipos de carcinomas obtidos (CDI, CDII, CDIII e CM) e fotos de lâminas representativas dos casos mais típicos dos carcinomas ductais. Optou-se por não mostrar as fotos do CM por elas não representarem o caso mais típico deste tipo de carcinoma.

\section{(c) - a) Carcinomas do tipo CDI, CDII e CDIII}

A figura 4.13-a mostra o perfil de espalhamento médio obtido para cada grau de alteração dos carcinomas ductais invasivos, bem como para a média geral de todos eles.

As figuras 4.13-b e 4.13-c mostram as fotos das lâminas típicas das amostras de CDI. Pode-se perceber que existe uma formação tubular, e o estroma começa a ser infiltrado pelas células tumorais. $\mathrm{O}$ tamanho das células tumorais é bastante homogêneo. Não há grande diferença no tamanho dos núcleos das células tumorais.

As figuras 4.13-d e 4.13-e mostram as fotos das lâminas típicas das amostras de CDII. Em relação às fotos dos CDI, pode-se perceber que já existe pouca formação 
tubular, o estroma já encontra-se mais infiltrado pelas células tumorais e o tamanho destas células é um pouco variado.

As figura e 4.13-f e 4.13-g mostram as fotos das lâminas típicas das amostras de CDIII. Em relação às fotos dos CDI e CDII, pode-se perceber que já não existe formação tubular, o estroma encontra-se quase totalmente infiltrado pelas células tumorais e o tamanho das células tumorais não é muito variado.

Conforme o esperado, todos os carcinomas apresentaram perfis de espalhamento parecidos ao perfil fibro-glandular. Apenas uma amostra de CDII apresentou pico adiposo. Embora o perfil de espalhamento e a foto de sua lâmina não tenham sido mostrados, pôde-se perceber através dela que a porção de tecido analisada apresentava componente adiposa.

Esperava-se encontrar uma tendência de aumento ou diminuição da intensidade dos picos de acordo com o grau de alteração do tumor, mas este fato não foi confirmado pelos perfis. Através da figura 4.13-a pode-se notar que embora o CDI e CDII apresentem tendência de aumento da intensidade, o CDIII não a apresenta. As possíveis explicações para isso são:

(i) o número de células tumorais e o volume de cada uma delas cresce à medida que aumenta o grau de alteração do tumor. Assim, tem-se uma maior quantidade de elementos espalhantes por unidade de volume, ocasionando uma tendência de aumento da intensidade como ocorre entre o CDI e o CDII, mas não para o caso do CDIII.

(ii) ocorre o crescimento do núcleo das células tumorais à medida que o grau de enfermidade do tumor aumenta. Desta forma o núcleo ocuparia um volume maior dentro da célula, diminuindo a quantidade de estruturas espalhadoras dentro dela. Isso ocasionaria uma menor quantidade de elementos espalhantes por unidade de volume. Sendo assim, seria natural esperar que a intensidade do pico do CDIII diminuísse. 

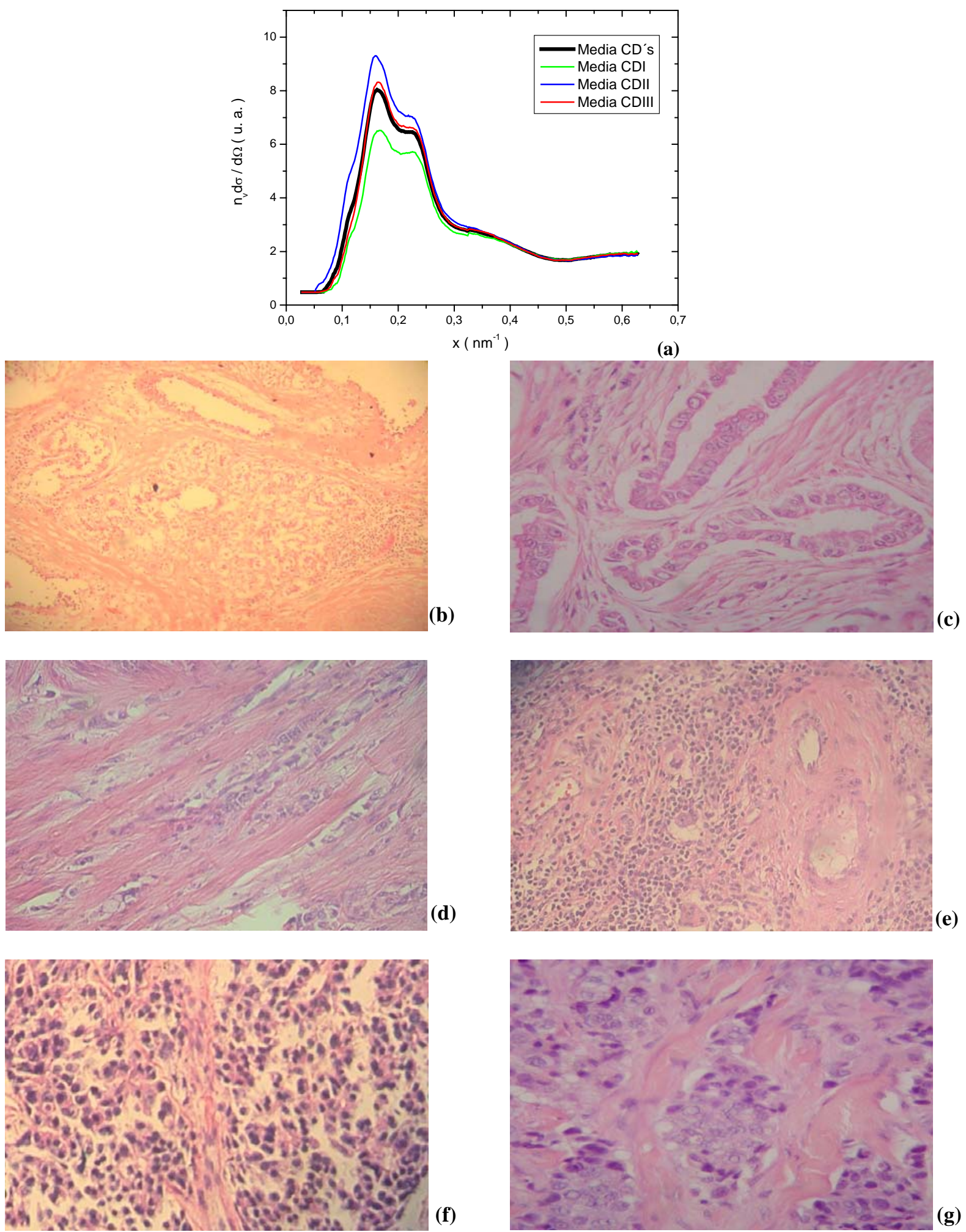

Figura 4.13: (a) perfil de espalhamento médio obtido para cada grau de alteração dos carcinomas ductais infiltrantes (CDI, CDII e CDIII) e para a média de todos eles; (b) e (c) fotos das lâminas típicas das amostras de CDI, (d) e (e) CDII, (f) e (g) CDIII. 


\section{(c) -b) Carcinoma do tipo CM}

Apenas uma amostra foi encontrada para o caso histológico do carcinoma mucinoso. A figura 4.14 mostra o perfil de espalhamento obtido para esta amostra. As fotos das lâminas não representavam o caso mais típico para este tipo de tumor e por esse motivo elas não são mostradas aqui. Assim como o caso dos carcinomas ductais, o carcinoma mucinoso também apresenta um perfil de espalhamento parecido ao tecido fibro-glandular.

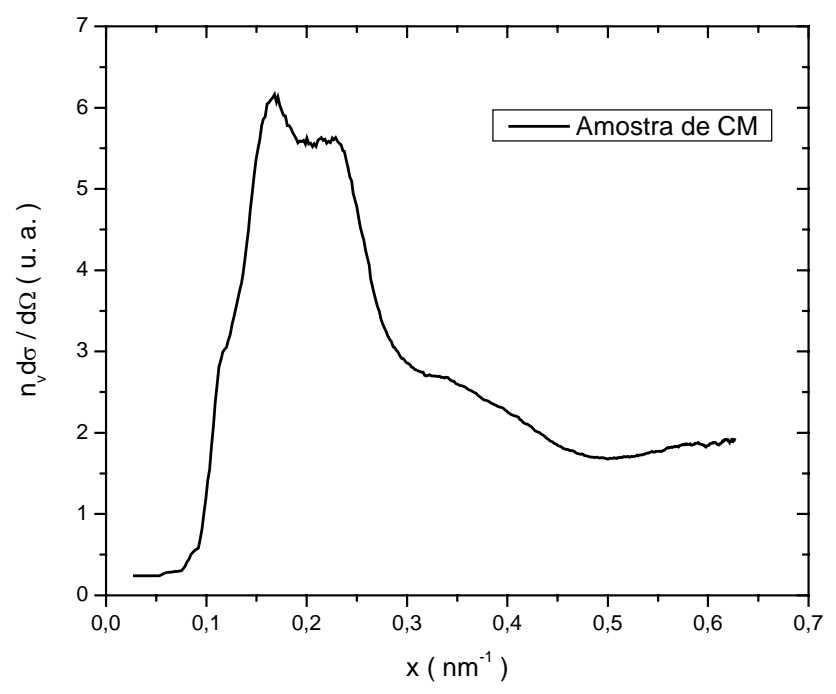

Figura 4.14: perfil de espalhamento do CM.

\subsection{3 - Comparação dos perfis de espalhamento obtidos com os dados encontrados na literatura}

A tabela 4.1 abaixo mostra a comparação de alguns parâmetros de caracterização dos perfis de espalhamento obtidos com os dados encontrados na literatura (KIDANE ET $A L, 1999$; POLETTI $E T A L, 2002)$. Esses parâmetros são: posição dos picos, intensidade relativa e largura a meia altura (LMA). Apesar de Evans et al (EVANS ET $A L, 1991)$ também já terem medido tecido mamário humano, seus resultados não foram 
comparados aqui por estarem discriminados em função do ângulo e não do momento transferido.

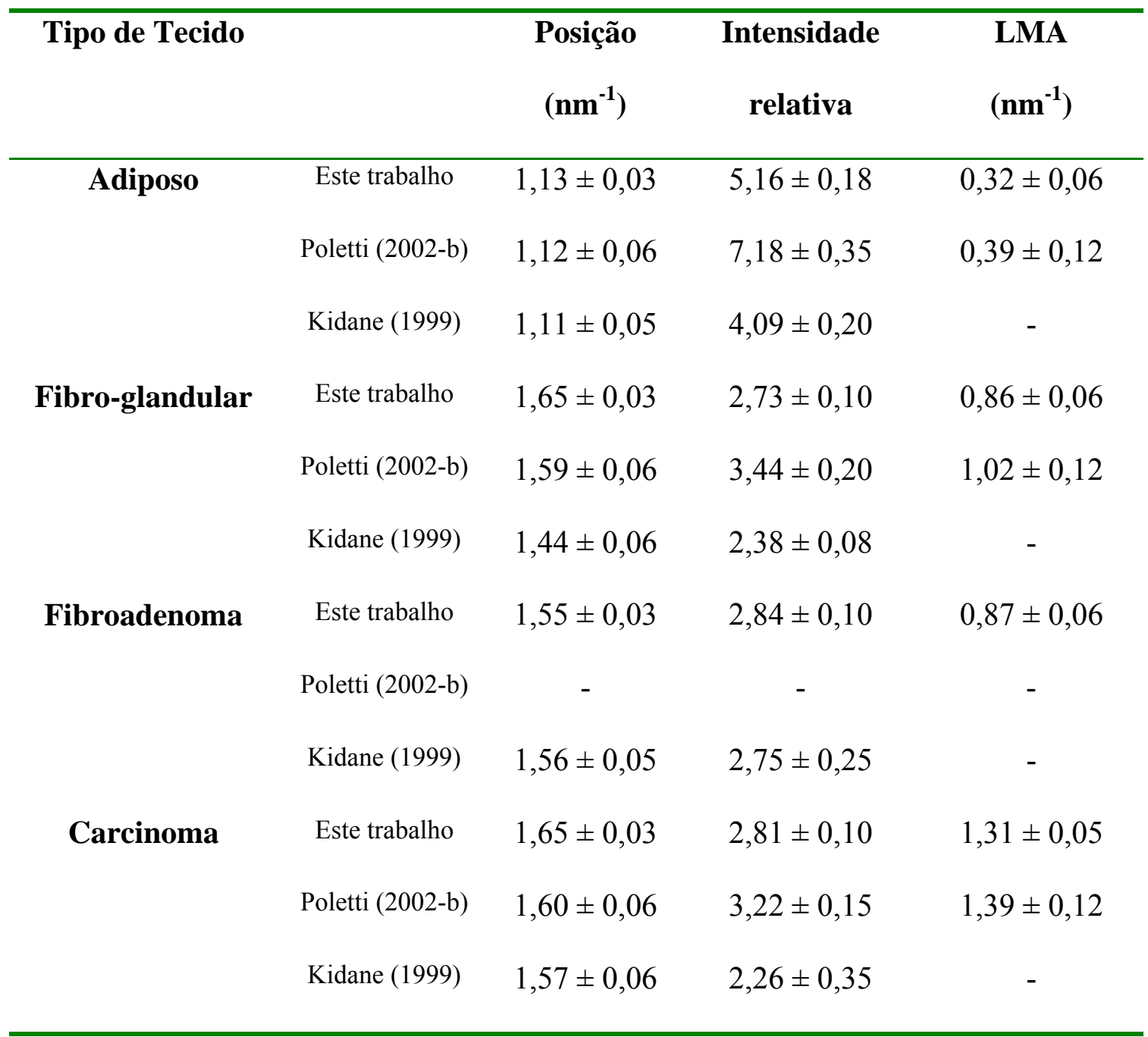

Tabela 4.1: Comparação dos parâmetros que caracterizam os perfis de espalhamento: posição do pico, intensidade, largura a meia altura (LMA).

Através da tabela pode-se ver que as posições dos picos e as LMA obtidas neste trabalho apresentam valores concordantes com os da literatura. Entretanto, as intensidades relativas obtidas por cada autor não mostram concordância entre si. A explicação para tais diferenças pode ser devida às diferentes técnicas de medidas, por exemplo, Kidane et al utilizou um feixe policromático ao invés de monocromático, 
implicando em uma pobre resolução do momento transferido e um perfil menos intenso (como visto na figura 4.15).

Tartari et al (TARTARI ET $A L, 1997)$ e Peplows \& Verghese (PEPLOWS E VERGUESE, 1998) apresentaram o perfil de espalhamento para tecido adiposo proveniente de animais, e Kidane et al (KIDANE ET AL, 1999) e Poletti et al (POLETTI $E L A L, 2002$-a e 2002-b) para tecido adiposo, glandular e carcinomas mamários. A figura 4.15 mostra as medidas dos perfis de espalhamento dos dados obtidos neste trabalho comparados com os dados existentes na literatura.

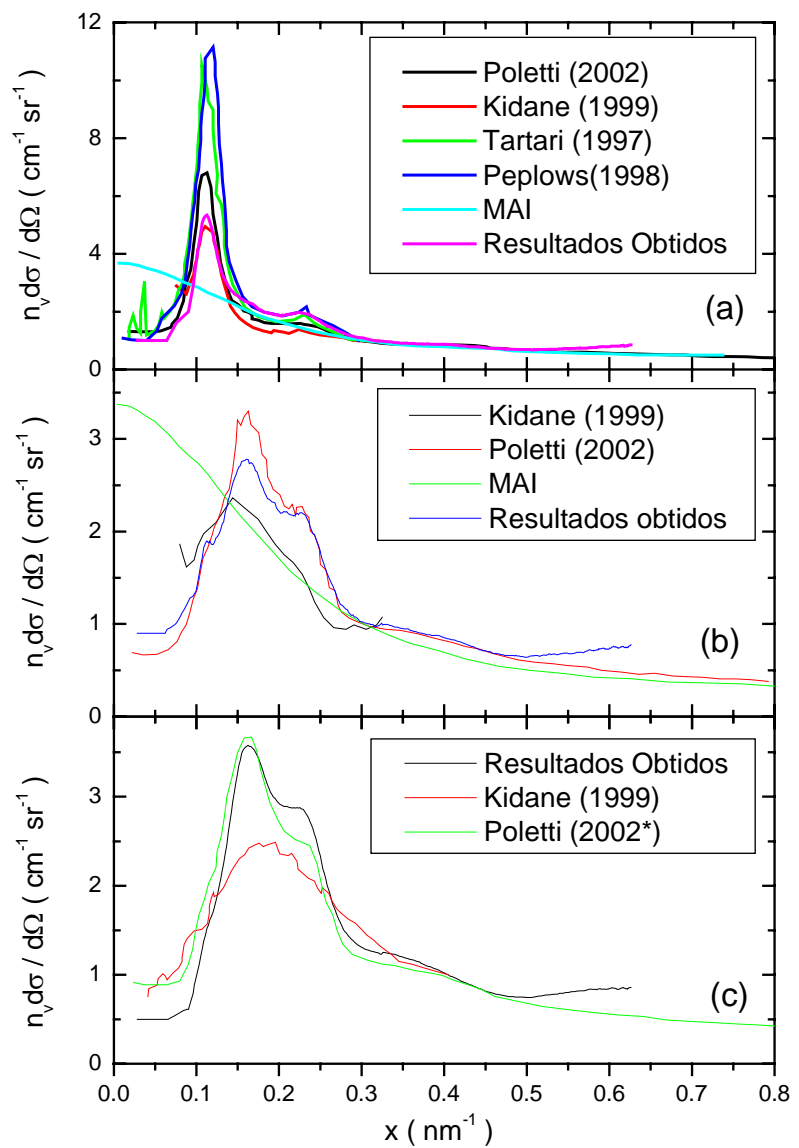

Figura 4.15: Comparação dos resultados obtidos nesse trabalho com os apresentados na literatura: (a) tecido adiposo, (b) glandular e (c) canceroso.

Através da figura 4.15, novamente, podemos notar que os perfis obtidos neste trabalho apresentam formas semelhantes e picos na mesma posição comparados aos resultados prévios, diferenciando-se apenas na intensidade. Apenas as medidas de 
Kidane et al apresentam posições levemente diferentes e forma mais achatada aos demais trabalhos, a explicação para isso é que possuía baixa resolução em momento transferido (POLETTI, 2001).

A concordância geral dos dados deste trabalho com trabalhos prévios indica que os presentes resultados dos perfis de espalhamento para tecidos normais e alterados são satisfatórios.

\subsection{4 - Potencialidades dos perfis de espalhamento como ferramenta para diagnóstico}

A figura 4.16-a apresenta um perfil de espalhamento médio obtido para cada tipo de tecido e na figura 4.16-b é feita uma diferença relativa entre o tecido normal e os tecidos alterados.
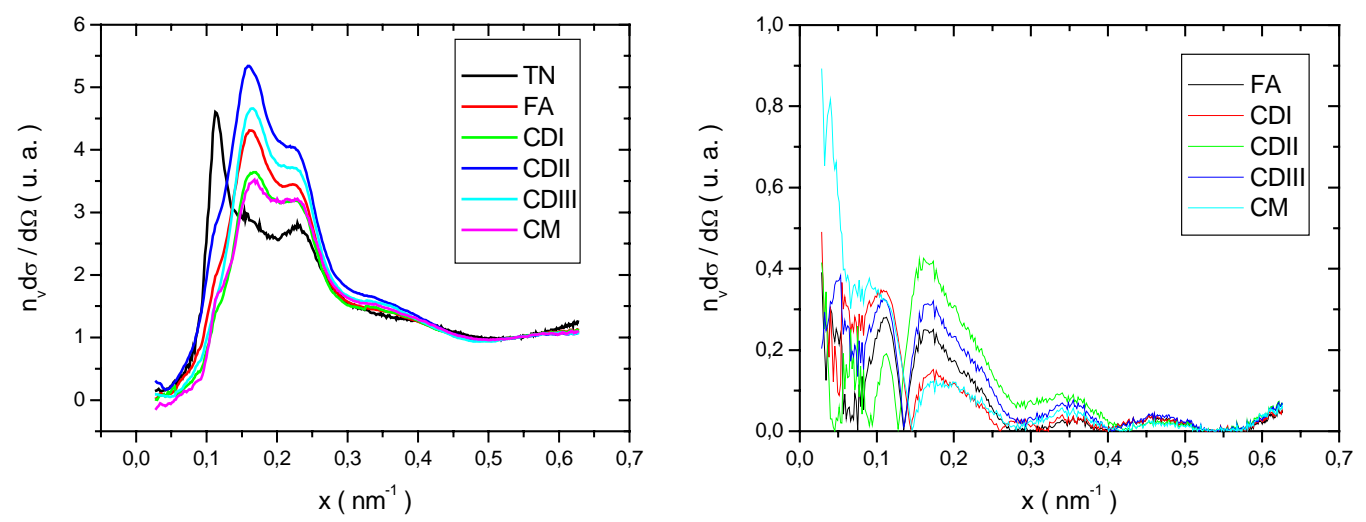

Figura 4.16: (a) perfil de espalhamento médio para cada tipo de tecido e (b) diferença relativa entre os tecidos alterados e o tecido normal.

Podemos ver que cada tecido apresenta um perfil de espalhamento médio diferente um do outro. A diferença notável ocorre entre tecido normal e alterado devido principalmente à presença do pico adiposo. A figura 4.16-b nos mostra que a principal faixa de diferenciação entre os tecidos ocorre para momentos transferidos menores que $0,35 \mathrm{~nm}^{-1}$. 
Embora a análise qualitativa dos perfis de espalhamento permita distinguir os diferentes tipos de tecidos, seria necessária uma análise estatística a fim de se confirmar estas hipóteses. Esta análise pode ser feita tomando-se parâmetros característicos de cada curva ou ainda analisando-se todo o perfil de espalhamento, utilizando para isso uma análise multivariada. Estes procedimentos estatísticos foram realizados por Cunha (CUNHA, 2006) e abaixo segue um resumo dos principais resultados obtidos.

\section{3 - Apresentação dos dados estatísticos de caracterização dos tecidos}

\subsection{1 - Modelo de diagnóstico utilizando variáveis simplificadas}

Para tentar diferenciar os perfis de espalhamento dos tecidos mamários, foram tomados alguns parâmetros de caracterização, tais como posição (P) e intensidade (I) do primeiro e segundo picos, sendo P1 e I1, P2 e I2, respectivamente. Além disso, outros parâmetros foram identificados como a largura a meia altura (LMA) e a relação entre I2/I1. A partir destas variáveis buscou-se identificar quais eram as que melhor forneciam uma separação entre os grupos, e que conseqüentemente poderiam ser utilizadas para classificá-los.

Para aumentar o número de amostra em cada grupo as amostras foram agrupadas em 3 grupos: grupo $\mathrm{TN}$ - grupo dos tecidos normais, grupo FA - grupo dos tumores benignos (fibroadenomas), e grupo $\mathrm{C}$ - grupo dos tumores malignos (carcinomas).

Uma vez que algumas variáveis apresentam distribuições não normais, além de heterorocedasticidade (variâncias não homogêneas) entre grupos, utilizou-se o teste de hipóteses não-paramétrico de Kruskal-Wallis (CALLEGARI-JAQUES, 2003). O teste foi realizado através do programa SPSS $13.0^{\circledR}$ versão para windows. 
A tabela abaixo mostra o resultado do teste, comparando tecidos normais, benignos e malignos. A coluna $\chi^{2}$ (CALLEGARI-JAQUES, 2003) dá a estatística do teste, e a $g l$ diz respeito aos graus de liberdade referentes ao número $g$ de grupos $(g l=g$ 1). Foram considerados significativamente diferentes grupos que apresentassem no teste um nível de significância $\alpha<0,05$ (CALLEGARI-JAQUES, 2003).

\begin{tabular}{cccc}
\hline Variável & $\chi^{2}$ & gl & $\alpha$ \\
\hline $\mathrm{P}_{1}$ & 29,110 & 2 & 0,000 \\
$\mathrm{P}_{2}$ & 11,077 & 2 & 0,004 \\
$\mathrm{LMA}$ & 28,669 & 2 & 0,000 \\
$\mathrm{I}_{1}$ & 7,893 & 2 & 0,128 \\
$\mathrm{I}_{2}$ & 4,111 & 2 & 0,000 \\
$\mathrm{I}_{2} / \mathrm{I}_{1}$ & 22,342 & 2 & 0,019
\end{tabular}

Tabela 4.2: Teste de Kruskal-Wallis para as variáveis P1, P2, I1, I2, LMA, e I2/I1.

Com exceção da variável $\mathrm{I}_{1}$, todas as outras apresentam diferenças entre os três grupos, como fica evidente pelos valores de $\alpha$ obtidos para cada variável.

Entretanto, o resultado deste teste deve ser analisado com cautela, pois é um teste que compara simultaneamente um número $g$ de grupos, e um resultado significativo não necessariamente implica que todos os grupos são diferentes entre si. A existência de um único grupo muito diferente dos demais pode tornar o teste significativo, mesmo que os demais sejam semelhantes entre si (CALLEGARIJACQUES, 2003). Então, como complemento ao teste de Kruskal-Wallis, foi feito um teste de comparação múltipla entre os grupos. Este teste analisa simultaneamente pares de grupos, e permite revelar quais são diferentes entre si. Um intervalo de confiança foi construído com nível de significância $\alpha=0,05$. Se os valores do eixo horizontal dos 
intervalos de cada grupo se sobrepõem, então aceita-se a hipótese de que não há diferença entre os grupos. Caso os intervalos estejam bem separados, conclui-se que os grupos são diferentes.

A figura 4.17 mostra os resultados da comparação múltipla para cada variável, exceto para $\mathrm{I}_{1}$, que não havia identificado nenhuma diferença entre os três grupos.

Analisando os intervalos de confiança obtidos entre os pares de grupos, nota-se que o grupo TN mostra-se diferente dos demais para todas as variáveis, exceto para $\mathrm{I}_{2} / \mathrm{I}_{1}$, que não diferencia entre normais e fibroadenomas. Os grupos FA e C, por outro lado, são iguais em todas as variáveis. Isso mostra que o resultado significativo obtido no teste de Kruskal-Wallis foi devido ao grupo TN. 

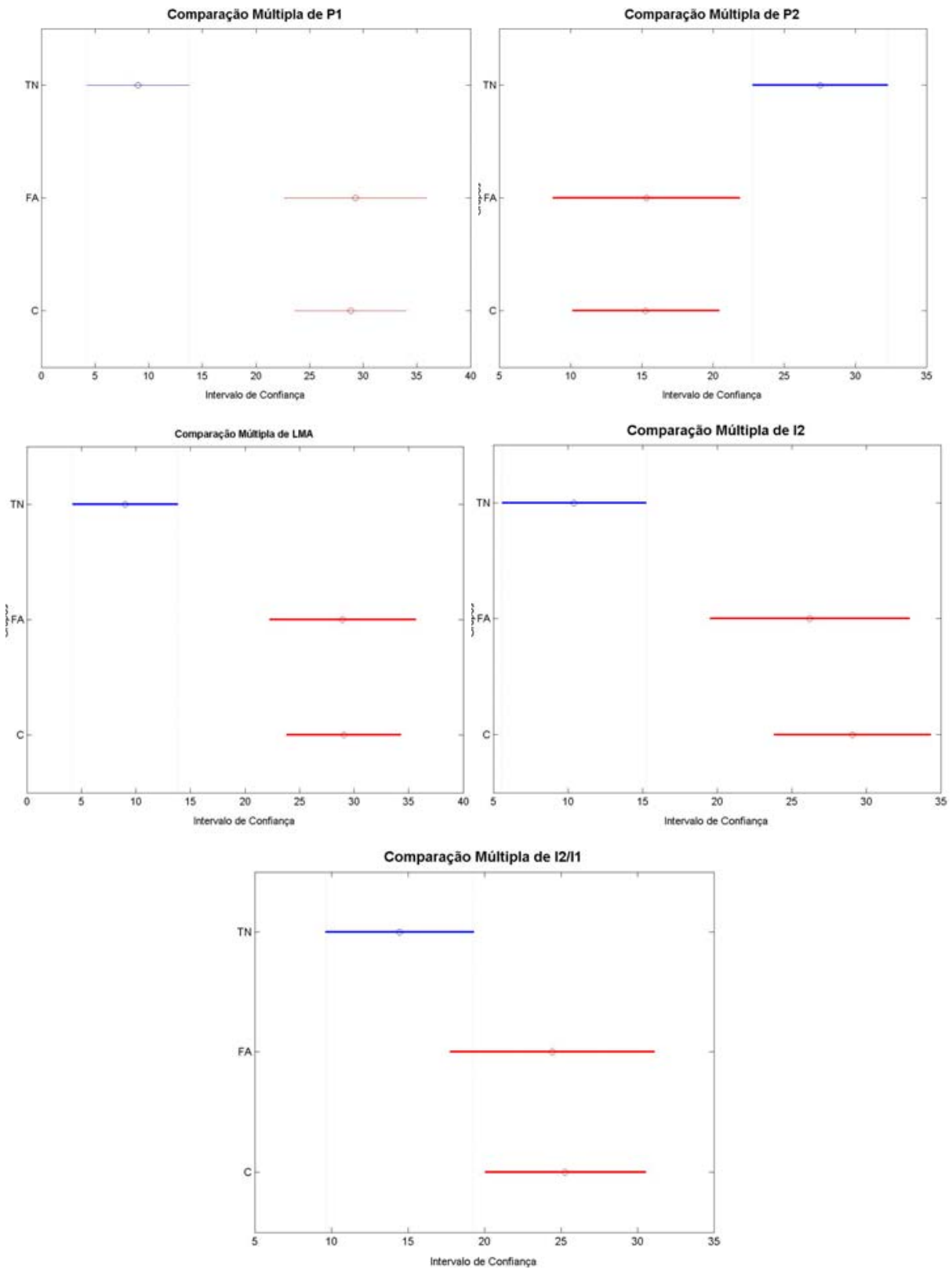

Figura 4.17: Intervalos de Confiança construídos para $\alpha=0,05$.

\subsection{2 - Modelo de diagnóstico utilizando análise de discriminante}

O modelo descrito anteriormente separa os tecidos normais dos alterados, mas não faz distinção entre os tipos de alteração. Para se observar estas diferenças foram realizados testes de análise multivariada. Estes testes conseguiram uma boa diferenciação entre os tumores benignos e malignos. O principal modelo diagnóstico foi 
obtido através do método de análise de discriminante, e está descrito resumidamente abaixo.

De todo o sinal espalhado medido experimentalmente, foi considerado para análise somente a região compreendida entre $15^{\circ}$ e $60^{\circ}\left(0,085-0,325 \mathrm{~nm}^{-1}\right)$ que é a região que apresenta maior variação entre os tecidos conforme visto na figura 4.16. Neste intervalo angular tem-se um conjunto de 136 variáveis, pois o detector, durante a realização do experimento, variava a posição angular em passos de $1 / 3$ de grau.

O critério de seleção de variáveis adotado neste trabalho foi a medida da distância $D^{2}$ de Mahalanobis (valor máximo de separação entre as populações JOHNSON E WICHERN, 2002) entre os centróides $\bar{Z}_{1}$ e $\bar{Z}_{2}$ de cada grupo, onde $Z_{1}$ e $Z_{2}$ são combinações lineares das variáveis selecionadas para este procedimento. $\mathrm{Na}$ primeira etapa as funções discriminantes são calculadas com a variável que maximiza a distância de Mahalanobis entre os três grupos. Nas etapas seguintes, as variáveis que também satisfazem a este critério são adicionadas sucessivamente ao cálculo das funções.

A figura 4.18 mostra as coordenadas de todos os elementos no plano $Z_{1} \times Z_{2}$, indicando a localização dos centróides $\bar{Z}_{1}$ e $\bar{Z}_{2}$ para cada grupo. 


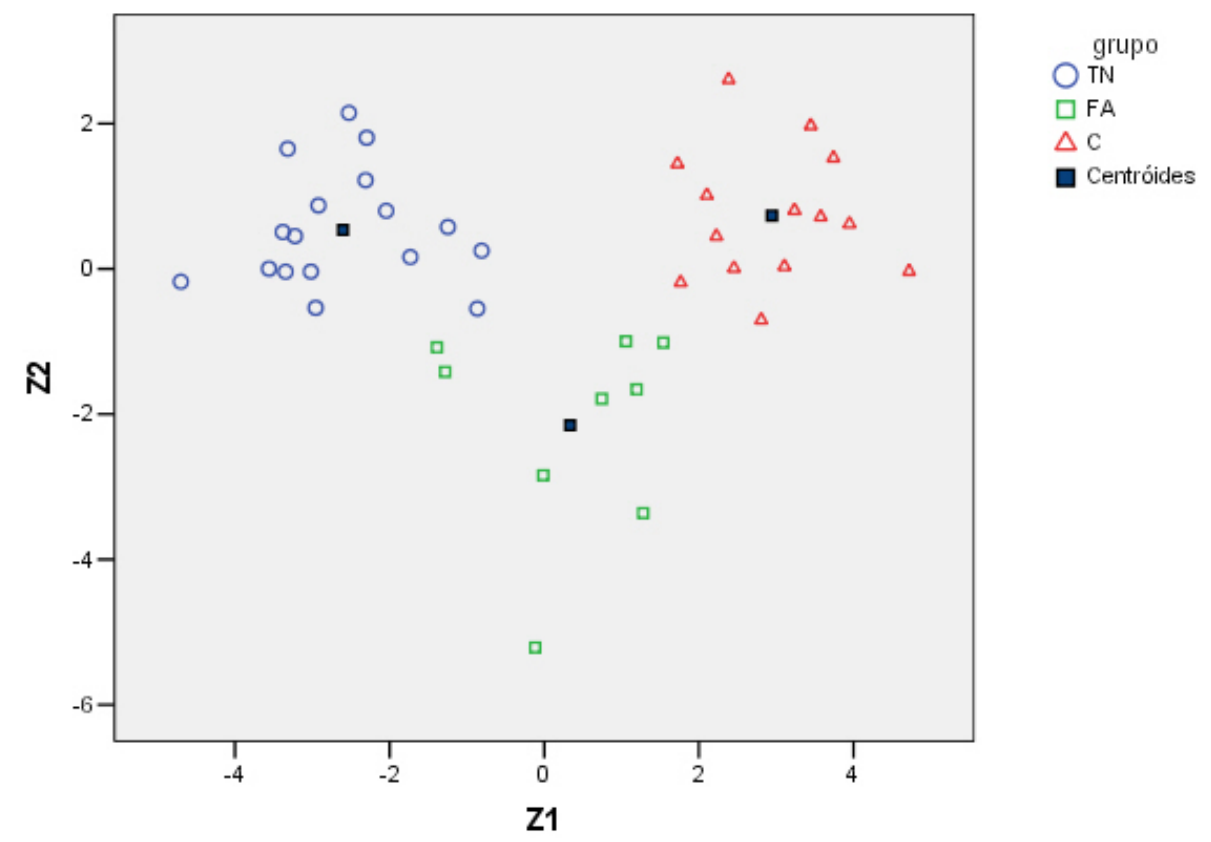

Figura 4.18: Coordenadas das amostras no espaço $Z_{1} \times Z_{2}$.

Nota-se que os grupos estão bem separados uns dos outros. Os grupos TN e C são os que apresentam melhor resultado, com todos os seus elementos distribuídos homogeneamente ao redor de seus centróides, e não muito distantes deles. Os elementos do grupo FA apresentam-se mais dispersos em relação ao centróide do grupo.

Uma comparação entre a classificação dos elementos a partir de suas distâncias aos centróides foi realizada. Apenas um elemento do grupo FA foi classificado erroneamente como normal. O índice de percentual de acerto neste caso foi de 97,5\%.

Para testar a eficiência das funções discriminantes como critério de classificação de novos elementos, foi realizado o processo de validação cruzada. Esse processo mostrou que $17,5 \%$ das amostras não foram classificadas corretamente, correspondendo a um índice de acerto geral de $82,5 \%$. Estas funções mantiveram um nível de sensibilidade (probabilidade do método detectar a alteração quando ela realmente está 
presente) bem próximo do de um exame mamográfico - 86,9\% na distinção entre normais e alterados e $100 \%$ entre tumores benignos e malignos.

O grupo TN apresentou $11,7 \%$ de seus elementos classificados como FA, e um caso de falso negativo, com um elemento do grupo C classificado como normal.

O grupo FA, por outro lado, teve praticamente metade de seus elementos classificados de forma errada. Um destes elementos classificados como TN possuía o pico de espalhamento adiposo em $20^{\circ}\left(1,126 \mathrm{~nm}^{-1}\right)$, que é característico dos tecidos normais, além do pico característico dos tecidos alterados. Esta característica provavelmente foi a responsável por sua localização próxima aos tecidos normais.

Pode-se perceber então que a análise dos perfis de espalhamento utilizando técnicas multivariadas para reconhecimento de padrões, como a análise de discriminante, permite a caracterização histopatológica correta da maior parte das amostras analisadas. Um aumento do número de amostras de tecido analisadas pode confirmar ou, até mesmo, melhorar o índice de acerto estatístico. 


\section{CAPÍTULO 5 - Conclusões e Perspectivas}

\section{1 - Sobre o método de obtenção dos perfis de espalhamento de amostras}

Para verificar a metodologia de medida e tratamento dos dados comparou-se o perfil de espalhamento obtido para a água com o resultado previamente publicado (MORIN, 1982). As diferenças encontradas foram menores que 9\%, dentro das incertezas experimentais, significando que a metodologia utilizada foi satisfatória.

A incerteza obtida no procedimento descrito neste trabalho foi de $9 \%$. Em pesquisas recentes, também utilizando difractômetros comerciais, Johns e Wismayer (JOHNS e WISMAYER, 2004) obtiveram incertezas experimentais de 20\%. A diminuição nas incertezas deste trabalho deve-se principalmente a combinação de correções experimentais e analíticas utilizada no procedimento de correção:

- subtração das contribuições espúrias levando-se em conta as frações de volume de ar e das amostras irradiadas (determinadas pelas condições geométricas);

- cálculo da atenuação considerando as diferentes formas de volume irradiado;

- correção pela área de irradiação constante (intensidade do feixe) obtida experimentalmente. 


\section{2 - Dos resultados obtidos para as medidas dos perfis de espalhamento de tecidos mamários}

A comparação realizada entre as medidas dos perfis de espalhamento e a análise das lâminas mostrou que é possível correlacionar os picos de espalhamento com o padrão morfológico dos tecidos mamários. Deve-se lembrar, que as lâminas não fazem uma representação direta dos elementos espalhadores de raios-X, pois mostram apenas os tipos de tecido que compõem a amostra. Entretanto, é a estrutura interna destes tecidos a responsável pelo espalhamento dos fótons incidentes.

As diferenças encontradas entre os resultados deste trabalho e os anteriormente publicados (posição de pico e intensidade relativa) podem ser explicadas de acordo com Poletti (POLETTI, 2001) por: (a) escolha dos intervalos de normalização para se obter a constante $K$, o que pode gerar discrepâncias maiores que $10 \%$; (b) diferentes composições das amostras utilizadas por cada autor, que pode gerar discrepâncias no cálculo da constante $K$; (c) baixa resolução em momento transferido no uso de sistemas de feixes polienergéticos ou baixa resolução angular, o que pode acarretar erros na posição, altura e largura do pico de espalhamento.

\section{3 - Potencialidades dos resultados}

Os resultados analisados mostram que o perfil de espalhamento pode ser muito útil na caracterização de tecidos mamários, principalmente na região de baixos momentos transferidos $\left(x<0,35 \mathrm{~nm}^{-1}\right)$, onde cada tipo de tecido medido apresenta uma 
distribuição característica (seção 4.2.4). Isto permite a diferenciação entre tecidos mamários normais e alterados.

Estudos estatísticos como os realizados por Cunha (CUNHA, 2006), utilizando as medidas obtidas neste trabalho, mostraram que foi possível classificar os tecidos mamários com uma sensibilidade equivalente à de um exame mamográfico $-86,9 \%$ na distinção entre normais e alterados e $100 \%$ entre tumores benignos e malignos. Este resultado indica que a radiação espalhada pode trazer informações complementares e úteis para o diagnóstico de anomalias na mama.

\section{3 - Perspectivas}

Este trabalho mediu e analisou o perfil de espalhamento de 83 amostras de tecido mamário. Um número maior de amostras ainda pode e deve ser medido para minimizar a incerteza estatística, e conseqüentemente, aperfeiçoar modelos diagnósticos, possibilitando uma maior sensibilidade e confiabilidade nos resultados.

As medidas analisadas aqui correspondem à faixa de momento transferido de $0,2 \leq \chi \leq 6,2 \mathrm{~nm}^{-1}$. Pesquisas recentes (POLETTI, 2006) indicam que na região de baixos momentos transferidos, $x \leq 0,2 \mathrm{~nm}^{-1}$, as medidas de espalhamento angular poderiam indicar um perfil característico das estruturas supra-moleculares, como por exemplo, do colágeno - mais presente em tecidos normais e menos nos tecidos alterados. 


\section{CAPÍTULO 6 - Referências Bibliográficas}

ATTIX, F.H. Introduction to radiological physics and radiation dosimetry. A Wiley. Interscience Publication, Madison, Wisconsin, 1986.

AZARROF, L.V. Elements of X-Ray Crystallography. USA: McGraw-Hill, 1968.

BARNES G.T. Mammography Equipment: Compression, Scatter Control and Automatic Exposure Control. In: Haus AG, Yaffe MJ, eds. Categorical Course in Physics (Technical Aspects of Imaging). Chicago: RSNA, 75, 1994.

BARNES G.T. Mammography Equipment: Compression, Scatter Control and Automatic Exposure Control. In: Haus AG, Yaffe MJ, eds. Categorical Course in Physics (Technical Aspects of Imaging). Chicago: RSNA, 75, 1994.

BARNES, G.T. Contrast and Scatter in X-ray Imaging. RadioGraphics 11: 307, 1991.

BARNES, GT. Characteristics of Scatter. In: Logan WW, Muntz EP, eds. Reduction dose mammography. New York: Masson, 223, 1979.

BLOOM H.J.G, RICHARDSON W.W. Histological granding and prognosis in breast cancer. A study of 1409 cases of which 359 heve been followed for 15 years. Br. J. Cancer: 11,1957.

BLUM, L. X-ray scattering from liquids with nearly spherical molecules. J. Comput. Phys. 7: 592, 1971.

BRADLEY, D.A., DANCE, D.R., EVANS, S.H., JONES, C.H. Quantitative measurements of small-angle gamma ray scattering form water, nylon, and Lucite. Med Phys. 16 (6): 851, 1989.

CAllegARI-JAQUES, S. M. Bioestatística: Princípios e Aplicações. São Paulo: Artmed Editora S. A., 2003.

CESAREO, R., HANSON, A.L., GIGANTE, G.E., Pedraza, L.J. Interaction of kev photons with Matter and New Applications. Physics Reports 213: 117, 1992. 
CHAN, H. P., DOI, K. Energy and Angular Dependence of X-Ray Absorption and its Effect on Radiographic Response in Screen-Film System. Physics in Medicine and Biology. v. 28, n. 5, p. 565-579, 1983.

COMPTON, A.H., A Quantum Theory of the Scattering of X-Rays by Light Elements. Phys. Rev. 21:483, 1923.

CUNHA, D.M. Caracterização de Tecidos Mamários Através de Modelos Estatísticos Utilizando o Espalhamento de Raios-X. Dissertação (Mestrado), Universidade de São Paulo, Faculdade de Filosofia, Ciências e Letras de Ribeirão Preto, Ribeirão Preto, 2006.

CURRY, T.S., DOWDEY, J.E. AND MURRY, R.C. Christensen's Physics of Diagnostic Radiology. Philadelphia: Lea \& Febiger, 1990.

EVANS, S.H., BRADLEY, D., DANCE, D.R., BATERMAN, J.E. AND JONES, C.H. Measurements of small-angle photon scattering for some breast tissues and tissue substitute materials. Phys. Med. Biol. 36: 7, 1991.

FERNANDEZ, M., KEYRILÄINEN, J., SERIMAA, R., TORKKELI, M., KARJALAINEN-LINDSBERG, M.L., TENHUNEN, M., THOMLINSON, W., URBAN, V., SUORTTI, P. Small-angle x-ray scattering studies of human breast tissue samples. Phys. Med. and Biol. 47: 577, 2002.

HARDING, G., KOSANETSKY, J., NEITZEL, U. X-Ray Diffraction Computed Tomography. Medical Physics, v. 14, n. 4, p. 515-525, 1987.

HAUS A.G. AND CULLINAN J.E. Recordin the Image - A History of the Radiological Sciences Ed. McClennan B.L. Radiology Centennial, INC. Reston, VA, 1996.

HUBBEL, J. H., VEIGELE, E. A., BRIGGS, E. A. BROWN, D. T. CROMER, D. T., HOWERTON, R. J. Atomic Form Factors, Incoherent Scattering Functions 
and Photon Scattering Cross Sections. Journal of Physical and Chemical Reference Data. v. 4, n. 3, p. 471-538, 1975.

JAMES, R.W. The optical Principle of the Diffraction of X-ray. London: Bell, 1962.

JOHNS, H. E., CUNNINGHAM, J. R. The Physics of Radiology. Springfield: Charles C. Thomas, 1983.

JOHNS, P. C., WISMAYER, M. P. Measurement of Coherent X-Ray Scatter Form Factors for Amorphous Materials using Diffractometers. Physics in Medicine and Biology. v. 49, n. 23, p. 5233-5250, 2004.

JOHNS, P.C., YAFFE, M.J., Coherent Scatter in Diagnostic Radiology, Medical Physics, v. 10, n. 40, p. 40-50, 1983.

JOHNSON, R.A, WICHERN, D.W., Applied Multivariate Statistical Analysis. $5^{\text {a }}$ Ed. New Jersey: Prentice Hall, 2002.

KANE, P.P., KISSELL, L., PRATT, R.H. AND ROY, S.C. Elastic scattering of Gama-ray and X-ray by atoms. Physics Reports 140: 75, 1986.

KIDANE, G., SPELLER, R.D., ROYLE, G.J., HANBTY, A.M. X-ray scatter signatures for normal and neoplastic beast tissues. Phys. Med. Biol. 44: 1791, 1999.

KOCH H.A., AZEVEDO C.M., BOECHAT A.L., ET AL. Radiologia da mama qualidade em mamografia. Radiol. Bras. 29: 257, 1996.

KOSANETZKY, J., KNOERR, B., HARDING, G., NEITZEL, U. X-Ray diffraction measurements of some plastic materials and body tissues. Med. Phys. 14 (4): 526, 1987.

LEHNINGER, A., NELSON,D. \& COX,M.M. Principles of Biochemistry. Ed. Worth Publishers, N.Y., 1993. 1013p. 
LIDE, R.D. (ed) 1996 CRC Handbook of Chemistry and Physics $77^{\text {th }}$ edn (Boca Raton, FL: Chemical Rubber Company)

MILBERG, M.E., Transparency Factor for weakly absorbing samples in X-Ray Diffractometry, J. Appl. Phys. 29(1):64, 1958.

MORIN, L.R.M. Molecular Form Factors and Photon Coherent Scattering Cross Sections of Water. Journal of Physical and Chemical Reference Data. v. 11, n. 4, p. 1091-1098, 1982.

NARTEN, A. H., LEVY. H. A. Liquid Water: Molecular Correlation Functions from W-Ray Diffraction. The Journal of Chemical Physics. v. 55, n. 5, p. 2263-2269, 1971.

NARTEN, N. X-Ray Diffraction Data on Liquid Water in the Temperatura Range 4C-200C. ORNL Report 4578, 1970.

PEPLOWS, D.E., VERGHESE, K. Measured molecular coherent scattering form factors of animal tissues, plastics and human breast tissue. Phys. Med. and Biol. 43: 2431, 1998.

POLETTI M.E. Análise do contraste, dose e desempenho de uma grade relacionada ao espalhamento na imagem mamográfica. Dissertação (Mestrado). Faculdade de Filosofia Ciências e Letras de Ribeirão Preto, Universidade de São Paulo, Ribeirão Preto, 1997-a.

POLETTI M.E. Estudo do Espalhamento de Fótons (6,94, 17,44 e 59,54 keV) em Tecidos Mamários, Materiais Equivalentes e sua Influência em Mamografia. Tese (Doutorado). Universidade Federal do Rio de Janeiro, Instituto de Física. Rio de Janeiro, 2001

POLETTI, M.E., ALMEIDA, A., REZENTES, P.S., JUNCK, K.L. AND BARNES, G.T. Performance of Mammographic grid. Phys. Med. XIII: 144, 1997-b. 
POLETTI, M.E., Estudo das organizações moleculares e supra-moleculares de tecidos mamários neoplásicos por espalhamento de fótons. Proposta de pesquisa realizada no LNLSíncrotron, 2006.

POLETTI, M.E., GONÇALVES, O.D., MAZZARO, I. Coherent and incoherentscattering of 17.44 and $6.93 \mathrm{keV} \mathrm{X}$-ray photons scattered from biological and biological-equivalent samples: characterisation of tissues. X-ray Spectrom. 31: 57, 2002-a.

POLETTI, M.E., GONÇALVES, O.D., MAZZARO, I. X-Ray Scattering from Human Breast Tissues and Breast-Equivalent Materials. Phys. Med. and Biol. 47: 47, 2002-b.

POLETTI, M.E., GONÇALVES, O.D., SCHECHTER, H. AND MAZZARO, I. Precise evaluation of elastic differential scattering cross-sections and their uncertainties in X-ray scattering experiments. Nucl. Inst. and Meth. Phys. Res. B. 187: 437, 2002-c.

POLETTI, M.E., GONÇALVEZ, O.D., MAZZARO, I. Measurements of X-ray scatter signatures for some tissue-equivalent materials. Nucl. Inst. and Meth. Phys. Res. B. 213: 595, 2004.

REISS, K.H. Scattered radiation and characteristic film curve. Radiology 80: 663, 1963.

ROSEN P.P. and OBERMAN H.A. Tumors of the mamary Gland - Atlas of Tumor Pathology 3 serie Fac. 7. Armed Forces Institute of Pathology, Washington, Dc, 1993.

ROSEN P.P. Breast pathology Lippincoh-Raven Publ. Philadelphia - New York, 1996. 
SEIDMAN H. AND MUSHINSKI M.H. Breast cancer incidence, mortality, survival and prognosis in Breast Carcinoma: Current Diagnosis and Treatment, edited by Feig S.A. and McLelland R. American College of Radiology and masson, New York, 1983.

SORENSON J.A. AND FLOCH J. Scatter rejection by air gaps: an empirical model. Med. Phys. 12: 308, 1985.

SPELLER, R. D., HORROCKS, J. A. Photon Scattering: A "New" Source of Information in Medicine and Biology?. Physics in Medicine and Biology. v. 36, n. 1, p. 1-6, 1991.

SPELlER, R.D. Tissue Analysis Using X-Ray Scattering. X-Ray Spectrom. 28: 244, 1999.

SPRAWLS P. Physical Principles of Medical Imaging. 2nd Edition. Medical Physics Publishing, Madison, Wisconsin, 1995.

STRID K. Analysis of secondary screening with special reference to grids for abdominal radiography. Acta Radiol. Suppl. 351:1, 1976.

STRYER, L. Bioquímica. Editora Guanabara Koogan, 1992. 881p.

STRYER, L. Bioquímica. Editora Guanabara Koogan, 2004.

TABAR L.,FABERBERG C.J.G., GAD A, ET AL. Reduction in mortality from breast cancer after mass screening with mammography. Randomized trial from the Breast Cancer Screening Working Group of the Swedish national Board of Health and Welfare. Lancet 1, 829, 1985.

TARTARI, A. Molecular differential cross-sections for low angle photon scattering in tissues. Rad. Phys. and Chem. 56: 205, 1999. 
TARTARI, A., BONIFAZZI, C., BARALDI, C. E CASNATI, E. Photon crosssections data from X-Ray Diffraction Pattern Measurements: correction procedure evaluations. Nucl. Instr. Meth. B 142: 203, 1998.

TARTARI, A., BONIFAZZI, C., FERNANDEZ, J.E., BASTIANO, M., CASNATI, E., BARALDI, C. E DOMENICO, G. DI. Molecular coherent scattering data for tissue in photon transport mont carlo codes. Appl. Rad. and Isot., 53: 901, 2000.

TARTARI, A., CASNATI, E., BONIFAZZI, C., E BARALDI, C. Molecular differential cross sections for $x$-ray coherent scattering in fat and polymethyl methacrylate. Phys. Med. and Biol. 42: 2551, 1997.

TARTARI, A., CASNATI, E., BONIfaZZI, C., E. Photon Scattering by Compounds: na Assesment of the Validity of the Independent Atomic Model Approximation. X-Ray Spec. 26: 169, 1997.

TARTARI, A., TAIBI, A., BONIFAZZI, C., BARALDI, C. Updating of form factor tabulations for coherent scattering of photons in tissues. Phys. Med. Biol. 47: $163,2002$.

THOMSON, J.J., Conduction Eletricity Through Gases. Cambridge, C.U.P., 1906.

VOET, D. \& VOET, J.G. Biochemistry. John Wiley, N.Y., 1995. 1361p.

ZAR, J. H. Biostatistical Analysis. 4 ed. Prentice Hall, 1999. 